\title{
3. SITE 388: LOWER CONTINENTAL RISE HILLS
}

\author{
Shipboard Scientific Party ${ }^{1}$
}

\section{SITE DATA}

Dates Occupied: 17-18 August 1975; 22-26 August 1975

Position: $35^{\circ} 31.33^{\prime} \mathrm{N}$; $69^{\circ} 23.76^{\prime} \mathrm{W}$

Water Depth: 4919 meters (corrected PDR), 4920 meters (drill pipe)

Penetration: 341 meters

Number of Holes: 2

Number of Cores: 11

Total Length of Cored Section: 98.5 meters

Total Core Recovered: 42.9 meters

Percentage Core Recovered: 44 per cent

Oldest Sediment Cored: Middle Miocene dark greenish gray hemipelagic clay at 341 meters sub-bottom

Basement: not reached

Principal Results: We abandoned Hole 388 because of an electrical failure on the derrick before we recovered the first core. Hole 388A penetrated 341 meters of Holocene turbidites and late-middle Miocene hemipelagic clay.

Gas is present in the Miocene hemipelagic clay at about 300 meters sub-bottom. We detected methane and ethane in ratios expectable in pelagic sediments, however, two attempts to take pressurized samples of the gas (which theoretically could have been in a clathrate form) failed when the ball valve of the pressure core barrel failed to close.

Glomar Challenger recorded a good seismic reflection profile across the lower continental rise hills during the site survey. The upper beds are apparently conformable with topography which virtually eliminates erosion as a possible origin for these features. Pliocene and late Miocene bedding structures are inclined under the ridges and swales whereas an upper-Miocene reflecting horizon is essentially planar. Cores taken across this horizon contain delicate bedding and burrow structures indicating that the reflector is not a surface above which beds were folded as would be the case if the continental rise hills were formed at the toe of a large regional slump. The seismic profile shows synclinal bedding under some of the ridges. This is compatible with the hypothesis that contour currents built the lower continental rise hills as constructional mud waves or "dunes" with dipping axial planes. Within the resolution of the seismic data, however, the features could also have been produced by local slumping.

Thus the results from Site 388 suggest that erosion and large-scale down-slope gliding are improbable mechanisms for the origin of the lower continental rise hills and that construction by contour currents is compatible with all the evidence. Local slumping could also have contributed to their formation.

\footnotetext{
'William E. Benson and Robert E. Sheridan, Chief Scientists; Paul Enos, Tom Freeman, Felix M. Gradstein, Ivar O. Murdmaa, Léo Pastouret, Ronald R. Schmidt, Daniel H. Stuermer, Fred M. Weaver, Paula Worstell.
}

\section{BACKGROUND, OBJECTIVES, AND STRATEGY}

\section{Background}

Site 388 lies about 350 miles east-southeast of Norfolk, Virginia (Figure 1). Here long low ridges at the base of the continental rise are a distinct topographic feature of the western Atlantic continental margin. They occur below 4000 to 5000 -meter water depths and have a characteristic ridge and swale topography (Figure 2). Data are sparse, but suggest that in the area of Site 388 the ridges strike nearly east-west.

Although the hills are topographically prominent, previous seismic reflection profiles reveal that the structural relief is restricted to the uppermost Tertiary sediments, below which beds, including reflecting horizon $A$, are horizontal (Figure 3). Origins postulated for the ridge and swale topography include (a) constructional development of mud ridges by contour currents, (b) erosion by bottom currents, or (c) deformation of the upper Tertiary sediments into ridges by down-slope gravity slumping. Construction by contour currents has been suggested by Heezen and Hollister (1974) and a possible slump origin has been proposed by Emery et al. (1970) and more recently by Schlee et al. (1976).

Evidence from seismic reflection profiles is equivocal. Some profiles suggest a bedding structure consistent with the constructional origin; others show internal structures that look like slump. In the area of Site 388 , the profiles available from Vema 23 show little or no structure in the acoustically transparent layer that forms the ridge and swale topography (Figure 3 ).

Horizon $A$, at a depth of about 490 meters at this site, is continuous with reflectors penetrated on Leg 11 (Hollister et al., 1972). Multicolored Upper Cretaceous or Eocene clays were cored just below this reflector at Sites 105 and 106 . The cores, however, were taken from widely spaced intervals above and below the seismic horizon and the exact nature of the reflector in this area is uncertain.

Another acoustic reflector, horizon $A^{*}$, is below horizon $A$, at a depth of about 700 meters. Horizon $A^{*}$ is widespread west of the Bermuda Rise but merges farther to the east with horizon $A$. At Site 105, this reflector is thought to mark the boundary between Upper Cretaceous multicolored clay and the underlying Cretaceous black clay. The sediments where $A$ and $A^{*}$ split were investigated on Leg 43 , and we expected to better document the $A^{*}$ reflector at Site 388.

Cores from previously drilled DSDP sites in the western Atlantic $(101,105$, and 387) all have a middle Cretaceous sequence of dark carbonaceous mud; some of it is black organic clay (Hollister et al., 1972; Lancelot et al., 1975). The carbonaceous mud is geologically important to our 


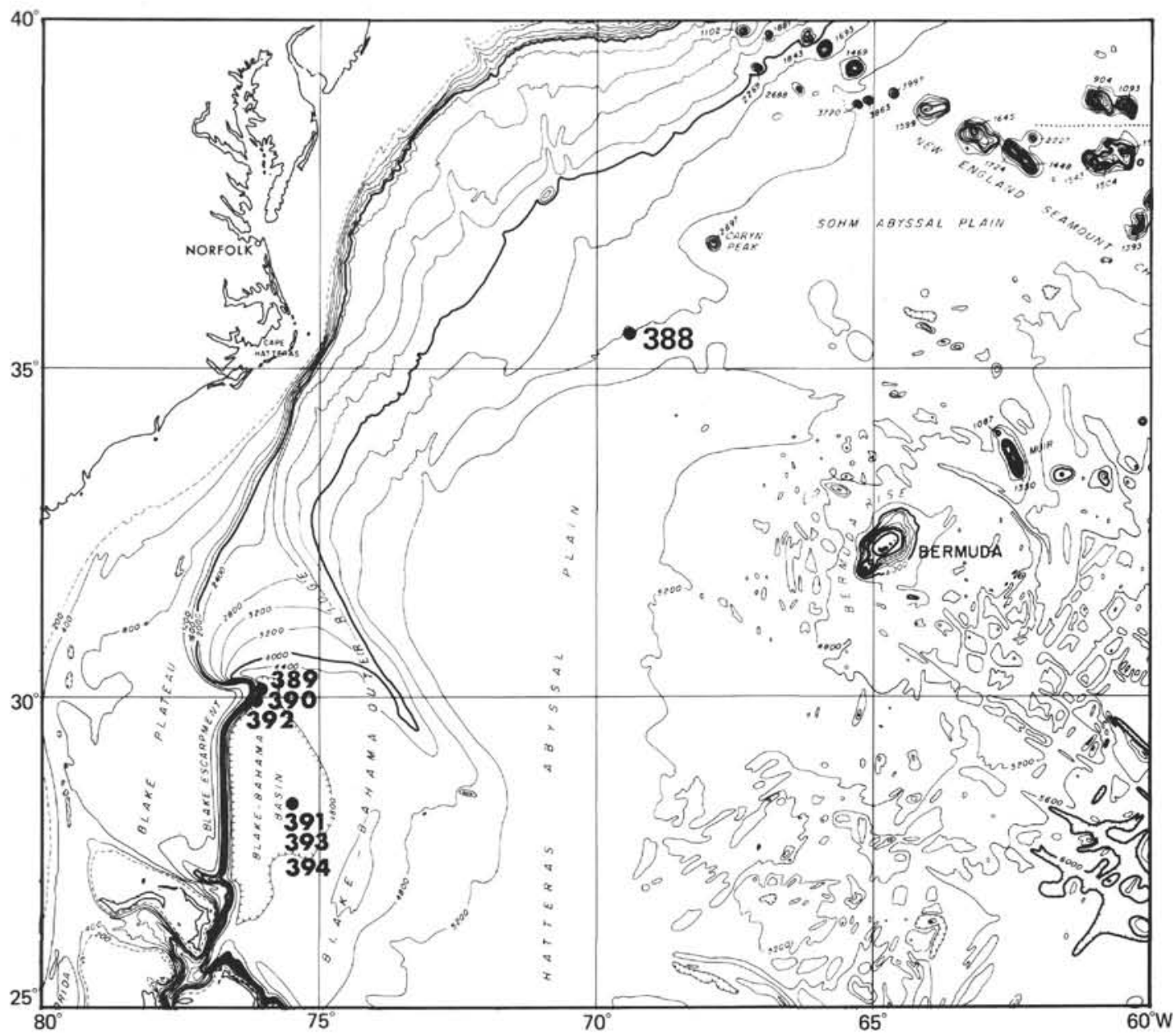

Figure 1. Location of Site 388 relative to the Atlantic margin.

understanding of stagnation of the deep Cretaceous basins in both the eastern and western Atlantic. We had hoped to encounter this sequence at Site 388 .

Although weak, horizon $\beta$ can be identified on the Vema 23 profile (Figure 3 ) at a depth of about 990 meters. At Site 105 of Leg 11 , horizon $\beta$ apparently represents the contact between the Cretaceous black clay and Neocomian-Tithonian white and gray limestone. This limestone unit was cored at closely spaced intervals during Leg 11 and is well documented in Holes 100, 101, and 105 (Hollister et al., 1972). A nearly identical Neocomian-Tithonian facies was recovered at Leg 41, Site 367, in the eastern Atlantic (Lancelot et al., 1975).

Results at nearby Site 105 indicate that the gray limestone overlies Kimmeridgian-Oxfordian red clayey limestone, which in turn overlies the basaltic basement. The basement at Site 105, however, was on a slight rise in the middle of rough topography (Hollister et al., 1972) and thus we cannot be certain that the oldest sediment in this area was recovered at Site 105.

When Site 105 was proposed, we thought it lay just within the eastern boundary of the "magnetic quiet zone" (Taylor et al., 1973). Now, we think that coring at Site 105 sampled basement in one of the reversely magnetized blocks of the Keathley sequence, which date anomaly M25 as about 153 m.y.B.P. (Larson and Hilde, 1975) (Figure 4). More recently van Hinte (1976) has revised the Jurassic time scale and his correlations place the age of M25 as about 145 m.y.B.P. Site 388 is well within the quiet zone, and drilling was planned to give more definitive data on magnetic anomaly dating.

The "magnetic quiet zone" is so called because its magnetic anomalies are less than 100 gammas. But the magnetic profile across it is far from flat and shows very definite traceable linear anomalies (Figure 5), e.g., the $E$ anomaly of Rabinowitz (1974), the Blake Spur (BS) anomaly of Taylor et al. (1968), and the $a$ anomaly of Drake et al. (1963). They are quite consistent in the western Atlantic south of the Kelvin Seamounts. These linear trends have been recently mapped off the Scotian Shelf (Barrett and Keen, 1976) so they appear to be consistent north of the Kelvin Seamounts as well. The origin of these anomalies and, indeed, the nature of the crust under the magnetic quiet zone have been disputed. Currently most workers accept that the crust east of the $E$ anomaly is oceanic (Rabinowitz, $1974)$ and that the characteristic basement reflector can be traced west of $E$ to near the east coast anomaly (Barrett and Keen, 1976). If so, then the quiet zone anomalies E, BS, and $a$ could be isochrons and pertinent to the Jurassic history of sea-floor spreading.

\section{Objectives}

Site 388 was drilled to help solve seveal problems involving plate tectonic theories, sea-floor spreading, 


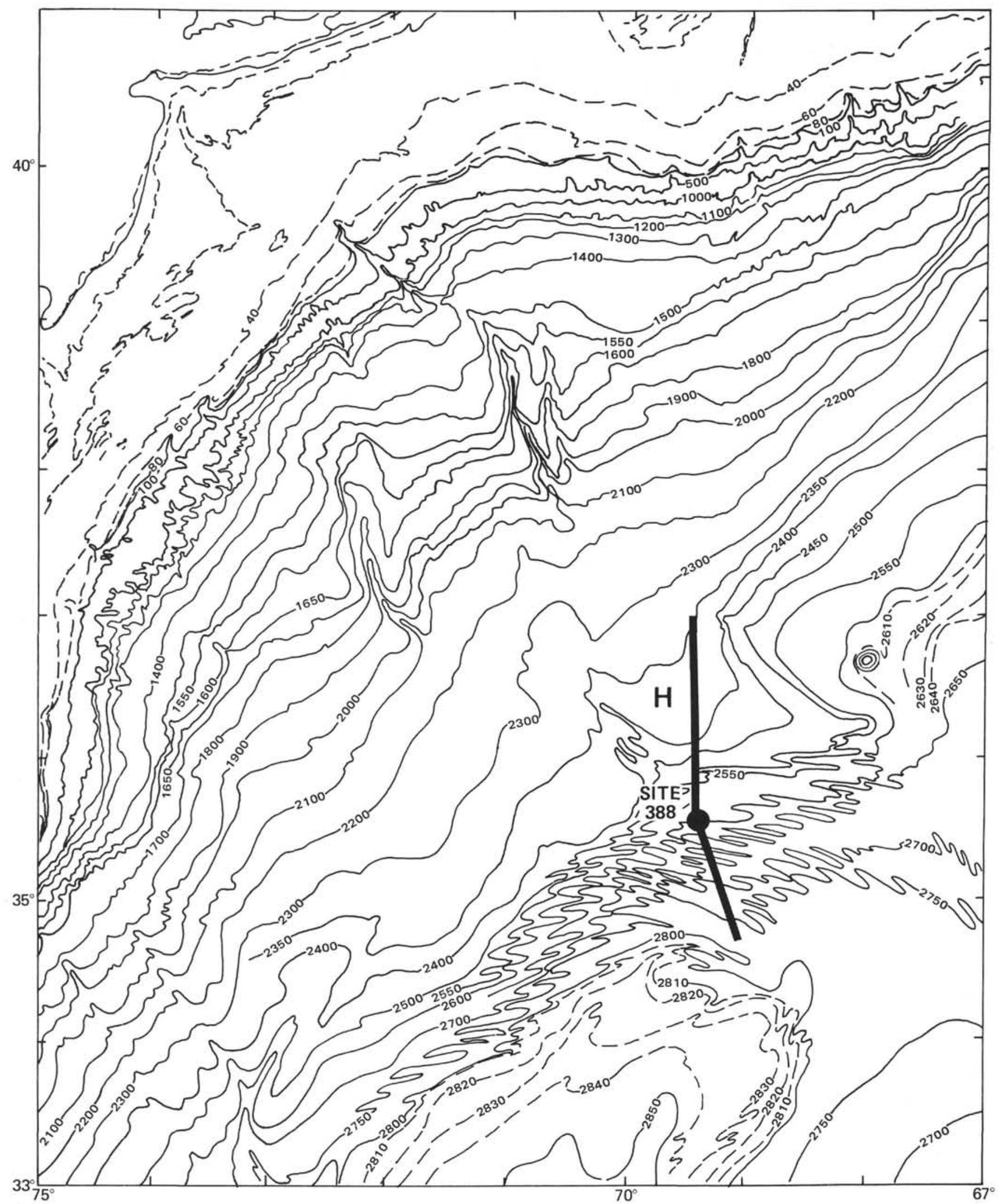

Figure 2. Detailed bathymetry in the vicinity of Site 388. Depths in fathoms are on basis of computations of E. Schneider (personal communication). Profile along track $\mathrm{H}$ is shown in Figure 3. 


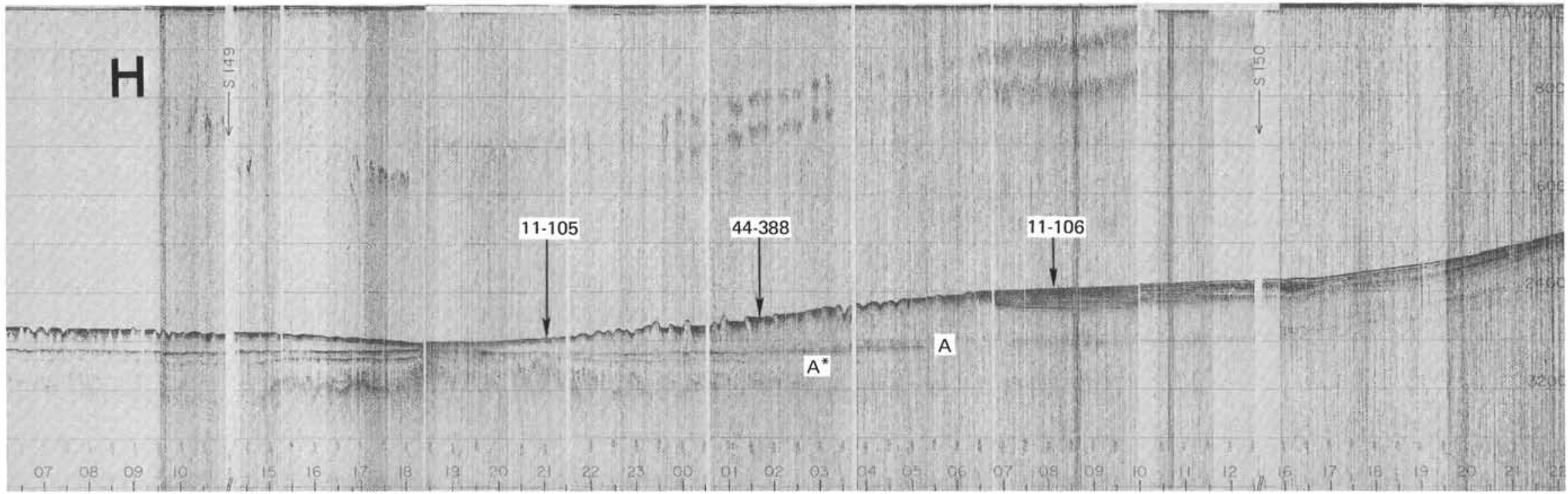

Figure 3. Vema 23 single-channel reflection profile along track $\mathrm{H}$ shown in Figure 2. (Data supplied by Lamont-Doherty Geological Observatory.) 


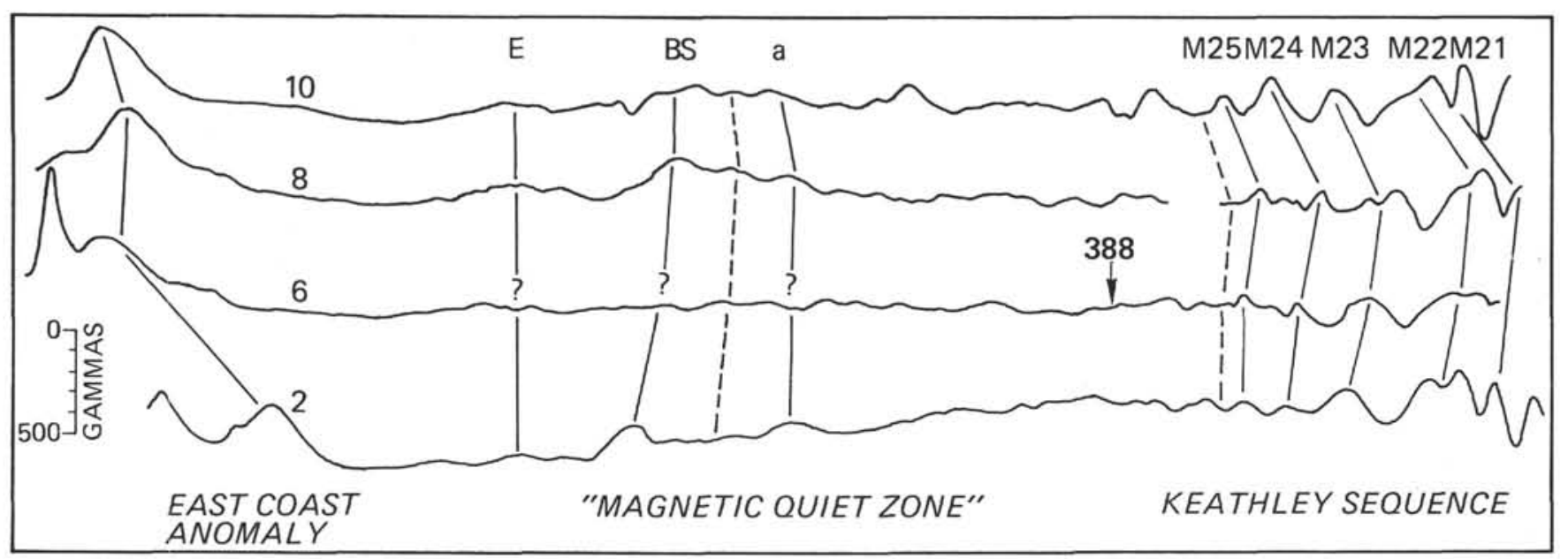

Figure 4. Marine magnetic anomaly profiles across the western Atlantic quiet zone near Site 388 (after Rabinowitz, 1974).

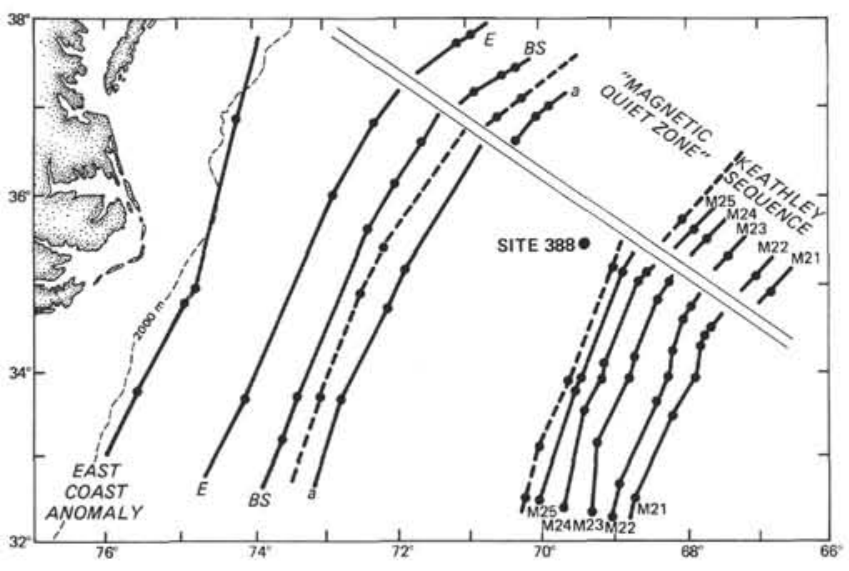

Figure 5. Mapped lineations of correlative magnetic anomalies near Site 388. Dots are identifications on ships' tracks.

structure of the continental margins, and acousticstratigraphic correlations. The major objectives at Site 388 were to:

1) determine the age and character of basement,

2) determine the origin of the lower continental rise hills,

3) document the precise lithologic and stratigraphic nature of the seismic reflectors, and

4) sample and study the lithologies, with particular emphasis on the carbonaceous clay and metalliferous limestone.

Age and character of the basement: Site 388 is well within the "magnetic quiet zone" (Figure 5) and its linear distance, perpendicular to strike, from the well-documented anomalies of $E, B S$, and $a$ and to the Keathley sequence is precisely known. Recovery of fossiliferous sediments from just above the basement would date the basement and allow calculation of Jurassic spreading rates by comparison with the presently known ages of the Keathley sequence (Larson and Hilde, 1975; van Hinte, 1976).

The "'magnetic quiet zone"' is thought by some (McElhinny and Burek, 1971) to represent ocean crust formed during a period of dominantly normal polarity - the Graham interval, 150-200 m.y.B.P. Other possible causes of the quiet zone include demagnetization by thermal metamorphism, or intrusion of the basement rocks under thick blanketing sediments (which would have inhibited quenching). Samples of the basement might resolve these questions.

Slump versus sedimentation origin of lower continental rise hills: If bedding structures from sediments forming the relief of the continental rise hills could be identified either as deformational distortions caused by slumping, or as depositional structures caused by sedimentary buildup, then we could resolve the question of the origin of these structures. At sites in the Gulf of Mexico (Site 1, Leg 1), for example, slumped beds were identified by recumbent chevron folds, rotated mica grains, and incipient cleavage in the claystones (Ewing et al., 1969). If the internal reflectors identified by Emery et al. (1970) and Schlee et al. (1976) are truly slip planes of slump surfaces, cores through these planes could be diagnostic. Depositional bedding, on the other hand, should be identifiable by consistent dips, reasonable angles of repose, and graded beds.

Stratigraphic correlations of seismic reflectors: Drilling at nearby Sites 105 and 106 of Leg 11 (Hollister et al., 1972) have established tentative correlations of the major reflectors $A, A^{*}$, and $\beta$. Reflector $A$ is either a Miocene-Eocene hiatus or Eocene cherts; $A^{*}$ is a contact between Upper Cretaceous variegated clay and Cretaceous carbonaceous mud, and $\beta$ is the top of Neocomian limestone below the black clay. However, coring in Hole 105 was discontinuous and the exact nature of these seismic reflectors and their corresponding lithologic contacts are unknown in the area of Site 388. We planned to continuously core across these boundaries.

Origins of sedimentary facies: The variety of facies expected at Site 388 reflects the very insignificant changes that the western Atlantic environment has undergone during the geologic past. For example, if the muds of the upper Tertiary were deposited in ridge and swale formations by strong bottom currents, strong thermohaline circulation must have existed. Also, the apparent reducing environment needed to preserve the organic material in the Cretaceous black clay suggests possible stagnation and lack of oxygen circulation. 
Other lithologies, such as the variegated clays between horizons $A$ and $A^{*}$, are reported to be rich in iron with siderite and ankerite concentrations. The gray and white limestone and red clayey limestone above basement are similar in microfacies and structure to limestone of similar age in the Alps. Further comparisons, both geochemical and sedimentologic, were to be made. We also hoped to prospect for native copper and nickel, found in the red limestone above basement at Site 105 of Leg 11 (Hollister et al., 1972), and investigate their analogy with those of metalliferous sediments in the Red Sea brines (Degens and Ross, 1969).

\section{Strategy}

Site 388 was selected on the basis of a Vema 23 profile (Figure 3) which showed the basement at $1.26 \mathrm{sec}$, in a water depth of 4875 meters $(6.50 \mathrm{sec})$. On the basis of past experience plus sonobuoy data from Lamont-Doherty Geological Observatory, velocities of $1.69 \mathrm{~km} / \mathrm{sec}$ and 2.13 $\mathrm{km} / \mathrm{sec}$ were assumed for the layers above horizon $A$ and between horizons $A$ and $A^{*}$, respectively; $2.30 \mathrm{~km} / \mathrm{sec}$ for the layer from $A^{*}$ to $\beta$; and $2.81 \mathrm{~km} / \mathrm{sec}$ for the layer below horizon $\beta$ to basement. Using these values, we calculated depth to basement at approximately 1275 meters. The thickness of sediments, especially of the hard Jurassic limestones, would require the use of the re-entry technique for multibit drilling.

We planned to spud the hole in a swale where ponded Pleistocene and/or Holocene turbidites overlie the pelagic mud that makes up the ridges. We also intended to sample possible clathrates with a high-pressure core barrel.

\section{OPERATIONS}

Leg 44 began when Glomar Challenger left Norfolk, Virginia, on 15 August 1975 at 2040 hours. $^{2}$ After cruising east-southeast for about $1 \frac{1 / 2}{2}$ days, we approached the coordinates of proposed Site 388 and crossed the reference Vema 23 reflection profile at about 0930 hours on 17 August. Following an extensive search for a suitable location we found a favorable swale in the bottom topography at 1530 hours and dropped a $16-\mathrm{kHz}$ long-life beacon at 1534 hours. Our interpreted track during the search is shown in Figure 6 and the reflection profile taken during the same time is shown in Figure 7. Site 388 is in a flat-bottomed swale at a depth of 4921 meters (corrected PDR depth; $2604 \mathrm{fm}$, uncorrected, and $2691 \mathrm{fm}$, corrected).

We cruised for 10 minutes beyond the site, pulled the geophysical gear, and returned to the site at 1558 hours. A second $13.5-\mathrm{kHz}$ beacon was dropped for operational comparison with the long-life beacon. Hydrophones were lowered at 1740 and automatic positioning was completed at 1815. Full thruster power was required to maintain position over the beacon because of the strong current from the southeast (estimated at 3.5 knots) at nearly right angles to wind and swell from the southwest.

At 1815 hours the rig crew lowered a three-bumper-sub bottom-hole assembly with a pinger-piston corer in the bit (suitable for use with the high pressure core barrel).

\footnotetext{
"Time is given in "local time" throughout the text of the operations
} section.

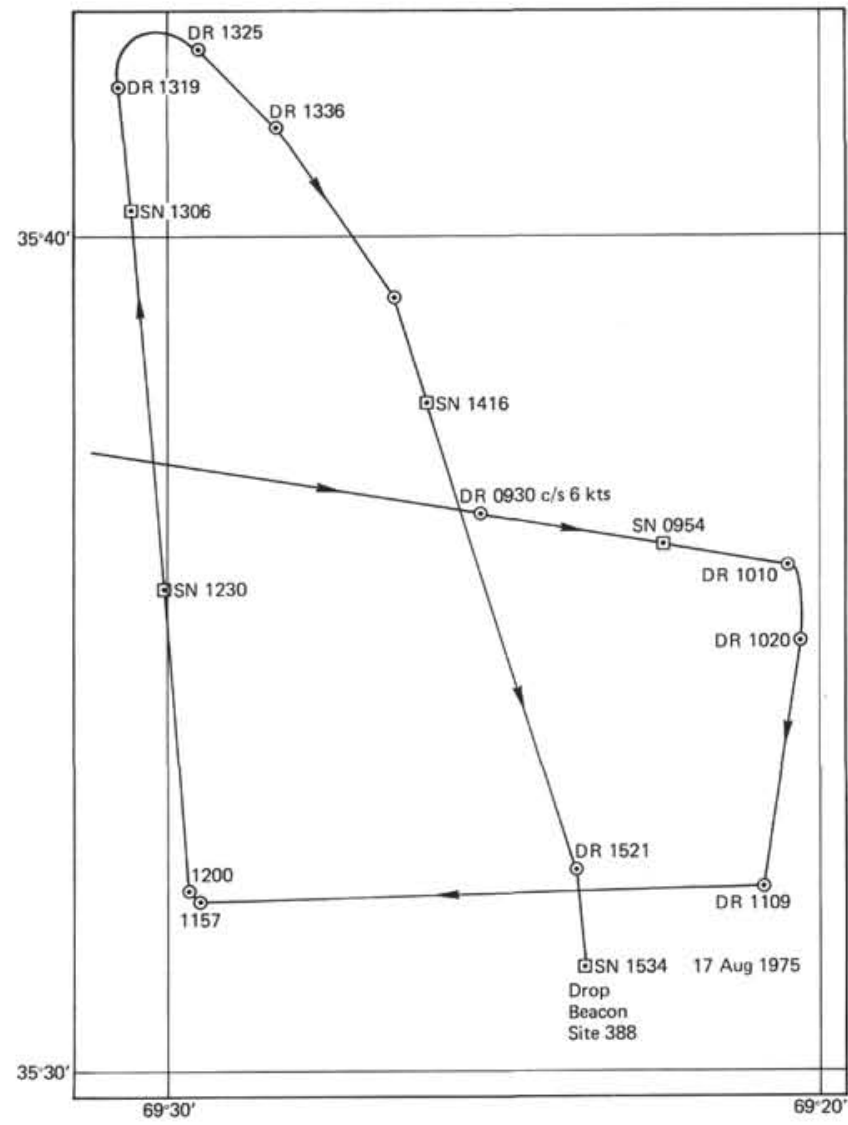

Figure 6. Track of Glomar Challenger during search for best location for Site 388. Local times are used.

However, at 0350 hours on 18 August the electric brake on the draw-works failed with 68 stands ( 90 feet/stand) of pipe down the hole. Fortunately the falling pipe was braked manually and no pipe was lost. The problem appeared to be a short circuit which could not be repaired by the ship's crew. Thus the pipe was pulled and the Challenger started back to Norfolk at 0900,18 August 1975 and arrived at Lynnhaven Roads anchorage at 0030 hours, 20 August. A Baylor Co. engineer located the short circuit, effected repairs, and following delivery of a new gyro for the positioning system, the Challenger again left Norfolk at 1630 hours, 20 August 1975.

We re-approached Site 388 at 0305 hours 22 August 1975. The seismic gear and magnetometer were pulled, and signals from the $13.5-\mathrm{kHz}$ beacon were picked up on the PDR at 0325 hours. Challenger then "homed in" on the beacon and hydrophones were lowered at 0410 hours and automatic positioning began at 0425 hours. The current was still from the southeast, but the southwest wind and swell had abated. Challenger was therefore headed at $150^{\circ}$ to stem the current, and the drill string was lowered for Hole 388 beginning at 0430 hours.

The water depth of the re-occupied site is 4919 meters (corrected PDR depth, $2602 \mathrm{fm}$, uncorrected, $2690 \mathrm{fm}$, corrected). This was consistent with the "drill pipe" depth as the pinger/piston core assembly touched bottom at 4930 meters below derrick floor (or $4920 \mathrm{~m}$ below the sea surface).

We were unable to successfully recover a core with the 


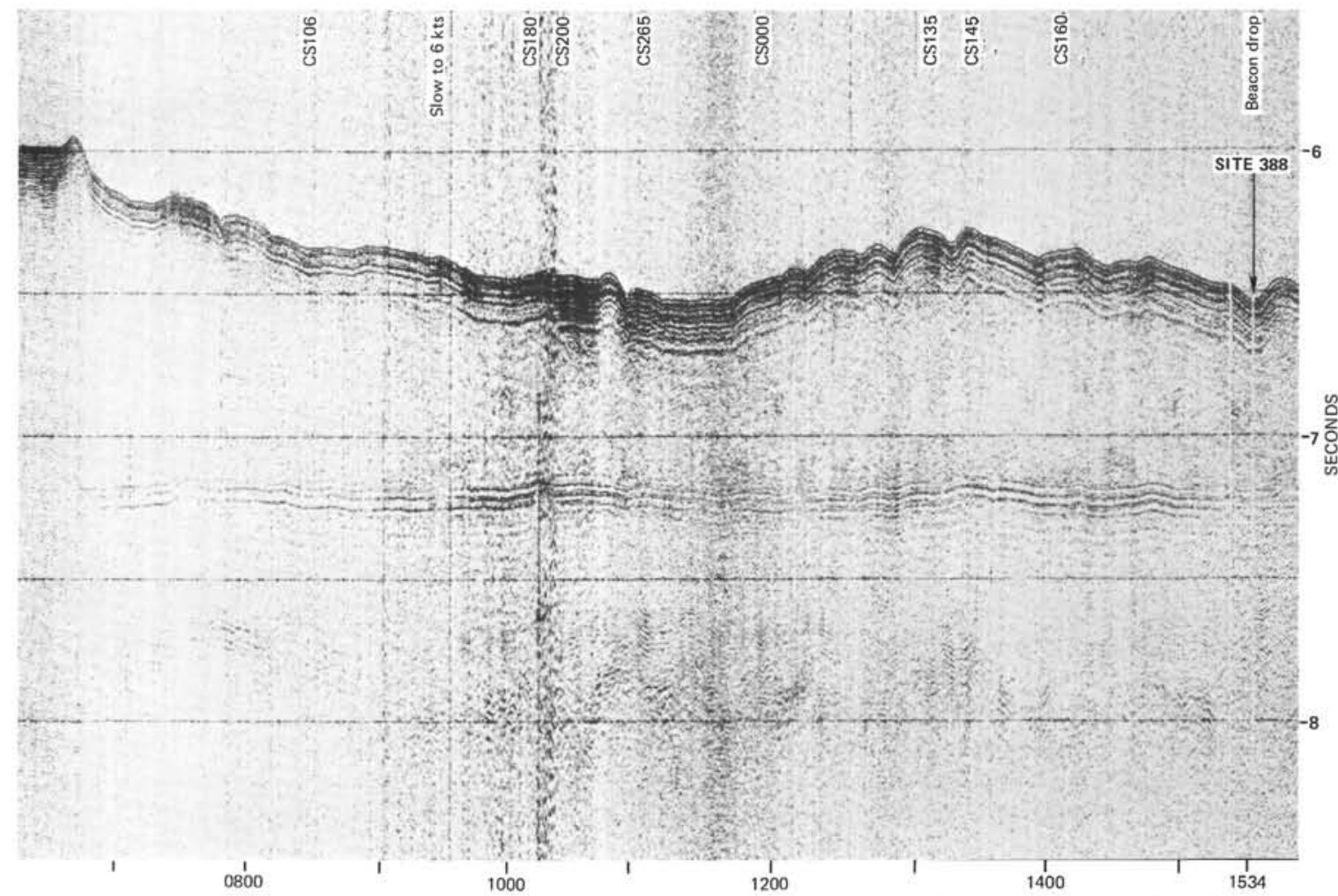

Figure 7. Single-channel airgun reflection profile made from Glomar Challenger during search for site location. Local times are used.

piston/pinger. It jammed in the bottom assembly and several attempts to retrieve it succeeded only in shearing the pins in the overshot. At 1800 hours, we began to pull pipe. When the bottom assembly was recovered we found that the inserts for a spacer had been incorrectly installed upside down. These inserts subsequently fell between the inner and outer core barrel causing the jam.

Because we had lost 5 days as a result of the brake failure and problem with the pinger/piston assembly, we decided to drill Site 388 without setting a re-entry cone. Experience with similar sediments on previous DSDP legs suggested that we should be able to penetrate 1275 meters to basement with a single bit. The 2 to 3 days saved by not setting the cone would, we hoped, help to recover some of the lost time. A drill pipe with a regular core barrel was spudded in Hole $388 \mathrm{~A}$ at 1510 hours on 23 August and a mud line core was on deck at 1625 hours.

Drilling and coring proceeded normally to 46.5 meters sub-bottom, where an unsuccessful test of the pressure core barrel (PCB) was made. When the PCB was retrieved, we found that it was not "locked"' in the upper section, and that sediments had squeezed around the lower ball valve thus preventing its closing. The plastic seat for the ball was also cracked which would have precluded sealing in any case, and finally, the liner was cracked, suggesting too hard an impact against the bit.

A second PCB test was made at 293.5 to 300.5 meters sub-bottom on 24 August, with an extended bit. Recovery of 5.5 meters of stiff clay suggested that the extended bit coupled with slow rotation is a viable technique for recovering unconsolidated sediments in spite of the small diameter of the PCB. But again, stiff clay prevented the lower ball valve from closing, and no pressure seal was achieved.

Drilling proceeded until the sand line became frayed and partly unraveled during retrieval of Core 9. Nearly 1000 meters of the sand line had to be cut off, and because the cable was then too short for further operations in Hole 388, a backup cable was transferred to the sand line winch.

The new cable was coated with line tar (preservative), which squeezed out under tension during its first run down the hole and fell down the drill pipe in large amounts. The line tar blocked the overshot from reaching the inner core barrel on run 11 and an attempt to "core the grease" with a second inner barrel was unsuccessful. Finally, at 0400 hours on 25 August, a one-meter "fishing" barrel was lowered on the sand line on the assumption that so short a barrel would not get stuck. This hope proved false when the new sand line abruptly parted while pulling on this tool.

With three core barrels plus some 2500 meters of cable down the hole, we had little choice but to pull pipe, and hope that some of the cable could be salvaged for splicing. When retrieved, however, less than 300 meters of cable was usable, and no attempt was made to splice it.

As the 5000 meters of cable remaining on the sand line winch was insufficient to reach bottom, Site 388 was abandoned. Core 11 was finally recovered, the tools laid on the deck, and Glomar Challenger left Site 388 on 26 August 1975 at 0330 hours, bound for the shallower site (389) on the Blake Nose. 
Eleven cores were recovered at Site 388 (Hole 388A). The hole terminated at 341 meters sub-bottom in middle Miocene hemipelagic clay. The coring results are summarized in Table 1.

\section{LITHOLOGY}

Only 341 meters of sediment were penetrated in Hole $388 \mathrm{~A}$ before operational difficulties forced us to abandon the site. We cored two distinct lithologic units, separated by a 144.5-meter gap in which no sediments were cored (Table 2 ). Both units are typical of the sediments of the uppermost part of the continental rise, sampled at DSDP Sites 105 and 106 (Leg 11).

An estimate of the major components in the dominant and minor lithologies are shown in Figures 8 and 9, respectively.

\section{Unit 1}

Unit 1 was sampled in Cores 1 through 3 down to a depth of 53.5 meters. The lower limit was not cored so the total thickness of the unit is unknown. Unit 1 consists of Holocene to lower Pleistocene terrigenous sediments ranging from coarse sand and silty clay to clay, with differing amounts of carbonate (mostly nannofossils that comprise up to 45 per cent of the more calcareous layers). Drilling disturbance obscured the sedimentary structures, but we noted some features suggestive of turbidites in Core 1. These features included (1) layers of terrigenous sand and silt alternating with intervals of calcareous (nannofossil) silty clay and clay, (2) rounded and subrounded grains of quartz sand indicative of shallow-water deposition, (3) probable shell fragments in the coarser sediments, (4) heavy minerals of typical continental provenance, and (5) pre-Pleistocene microfossils reworked into Pleistocene sediments. Both the upper and lower boundaries of the sandy layers are sharp and the sand is uniform in texture; the sands are not graded.

The dominant sediment types in unit 1 are calcareous (nannofossil) silty clay, marly nannofossil ooze with 30 to 45 per cent $\mathrm{CaCO}_{3}$, and calcareous clay with minor amounts of silt. The finer grained sediments probably represent upper parts of turbidite sequences or interbeds of hemipelagic sediments in a turbidite-bearing sequence. Core 2 consists almost entirely of the fine-grained material.

Core 1, Core 2, Section 2, and Core 3 are olive-gray (5Y4/1) with lighter gray (5Y5/1) carbonate-rich layers. Grayish brown layers (2.5Y5/2 and 10YR5/2) occur in Core 2 , Section 2, at 30-104 cm and a brown (7.5YR5/2) silty clay layer containing 18 per cent $\mathrm{CaCO}_{3}$ occurs in Core 2, Section 3. This interval contains oxidized glauconite(?) and iron-stained quartz grains.

All varieties of the silty clay and ooze are similar in composition, differing only in the amount of nannofossils and terrigenous silt. The principal constituent in every variety is terrigenous clay. The silt consists predominantly of quartz with minor amounts of feldspar, mica, and traces of heavy minerals. Carbonate is largely in the form of coccoliths and rarely occurring foraminifers (Figure 8 and Table 3). Dolomite(?) rhombs $2-40 \mu \mathrm{m}$ in size are fairly common; siderite(?) is rare.

TABLE 1

Coring Summary, Site 388

\begin{tabular}{|c|c|c|c|c|c|c|c|}
\hline Core & $\begin{array}{l}\text { Total Depth } \\
\text { (m) }\end{array}$ & $\begin{array}{l}\text { Sub-Bottom } \\
\text { Depth } \\
\text { (m) }\end{array}$ & $\begin{array}{l}\text { Cored } \\
(\mathrm{m})\end{array}$ & $\begin{array}{l}\text { Recov } \\
\text { (m) }\end{array}$ & $\begin{array}{l}\text { ered } \\
\qquad(\%)\end{array}$ & Lithology & Age \\
\hline \multicolumn{8}{|c|}{ Hole 388} \\
\hline 1 & $4930.0-4955.0$ & $0.0-25.0$ & 9.0 & 0.0 & 0 & - & - \\
\hline \multicolumn{8}{|c|}{ Hole 388A } \\
\hline 1 & $4930.0-4938.5$ & $0.0-8.5$ & 8.5 & 4.2 & 49 & $\begin{array}{l}\text { Calcareous silty clay, } \\
\text { marly nannofossil ooze, } \\
\text { sand, sandy silt and } \\
\text { silty clay }\end{array}$ & Pleistocene \\
\hline 2 & $4967.0-4976.5$ & $37.0-46.5$ & 9.5 & 3.8 & 40 & $\begin{array}{l}\text { Calcareous clay and } \\
\text { marly nannofossil ooze }\end{array}$ & Pleistocene \\
\hline $3^{\mathrm{a}}$ & $4976.5-4983.5$ & $46.5-53.5$ & 7.0 & 0.15 & 2 & Calcareous clay & Pleistocene \\
\hline 4 & $5138.0-5147.5$ & $208.0-217.5$ & 9.5 & 0.8 & 8 & Silty clay & Upper Miocene \\
\hline 5 & $5176.0-5185.5$ & $246.0-255.5$ & 9.5 & 9.5 & 100 & Clay and silty clay & Upper Miocene \\
\hline 6 & $5214.0-5223.5$ & $284.0-293.5$ & 9.5 & 1.7 & 18 & Clay & Upper Miocene \\
\hline $7^{\mathrm{a}}$ & $5223.5-5230.5$ & $293.5-300.5$ & 7.0 & 5.5 & 79 & Clay & Upper Miocene \\
\hline 8 & $5233.0-5242.5$ & $303.0-312.5$ & 9.5 & 1.3 & 14 & Clay & Upper Miocene \\
\hline 9 & $5242.5-5252.0$ & $312.5-322.0$ & 9.5 & 7.0 & 74 & Clay & Middle and upper Miocene \\
\hline 10 & $5252.0-5261.5$ & $322.0-331.5$ & 9.5 & 1.1 & 12 & Clay & Middle Miocene \\
\hline 11 & $5261.5-5271.0$ & $331.5-341.0$ & 9.5 & 7.8 & 83 & Clay & Middle Miocene \\
\hline Total & 5271.0 & 341.0 & 107.5 & 42.85 & 40 & & \\
\hline
\end{tabular}

${ }^{\mathrm{a}}$ Pressure core barrel 
TABLE 2

Summary of Lithologic Units, Site 388

\begin{tabular}{c|l|l|l|lc}
\hline \multirow{2}{*}{ Unit } & \multicolumn{1}{|c|}{ Lithology } & \multicolumn{1}{|c|}{ Age } & Thickness & $\begin{array}{l}\text { Sub-bottom } \\
\text { Depth }\end{array}$ & Cores \\
\hline 1 & $\begin{array}{l}\text { Calcareous silty clay; } \\
\text { marly ooze; terrigenous } \\
\text { sand and silt } \\
\text { (turbidites) }\end{array}$ & $\begin{array}{l}\text { Holocene-Upper } \\
\text { Pleistocene }\end{array}$ & $\begin{array}{l}\text { Minimum of } \\
53.5 \text { meters }\end{array}$ & $\begin{array}{l}\text { Cored } \\
0-53.5 \\
\text { meters }\end{array}$ & 1.3 \\
\hline 2 & $\begin{array}{l}\text { Clay; silty clay (hemi- } \\
\text { pelagic sediments) }\end{array}$ & $\begin{array}{l}\text { Upper Miocene- } \\
\text { middle Miocene }\end{array}$ & $\begin{array}{l}\text { Minimum of } \\
133 \text { meters }\end{array}$ & $\begin{array}{l}\text { Cored } \\
208-341 \\
\text { meters }\end{array}$ & $4-11$ \\
\hline
\end{tabular}

The sand-size sediment of unit 1 consists predominantly of quartz, with minor amounts of feldspar and heavy minerals (hornblende, epidote-zoisite, biotite, muscovite, zircon, etc.). The quartz grains are commonly round or subround. The carbonate content is low and consists of large foraminifers and unspecified calcareous debris.

Grain-size determinations were made on 6 samples following the cruise (see Appendix II, this volume). Five samples are silty clay and one from a coarse interlayer contains almost equal portions of each constituent. Clay content ranges from 31.5 to 74.7 per cent (average 59.9\%), silt from 24.1 to 41.0 per cent (average $33.5 \%$ ), and sand from 1.0 to 27.4 per cent (average $6.5 \%$ ). Sorting is rather poor.

A single sample of the coarse fraction $(>50 \mu \mathrm{m})$ was analyzed. The light fraction is composed of quartz (63\%) and feldspar $(17 \%)$ with minor amounts of altered grains and mica (biogenic carbonate and opal are excluded). The principal minerals of the heavy fraction are opaque minerals

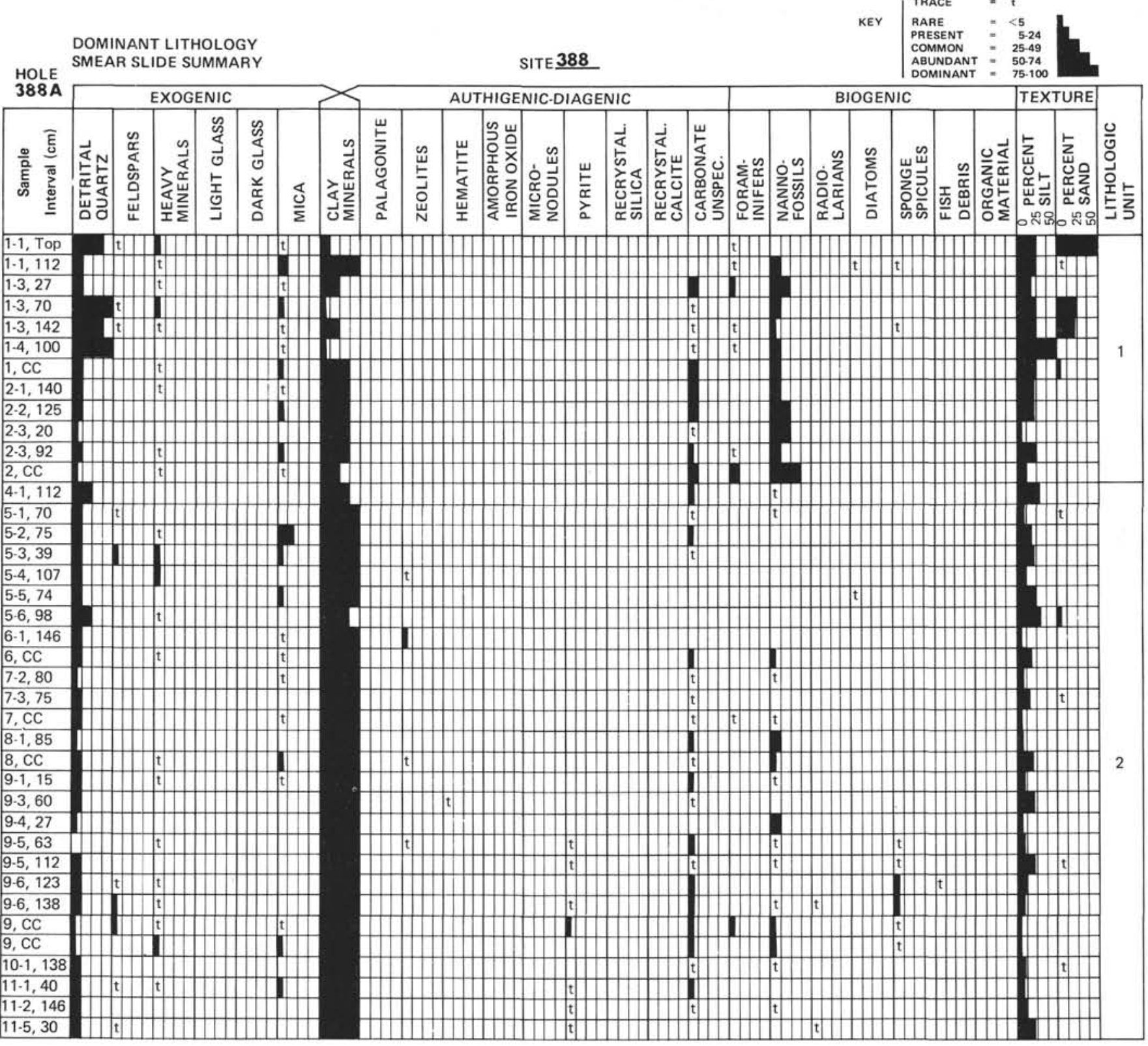

Figure 8. Estimate of major components in dominant lithologies from smear slides, Hole $388 \mathrm{~A}$. 


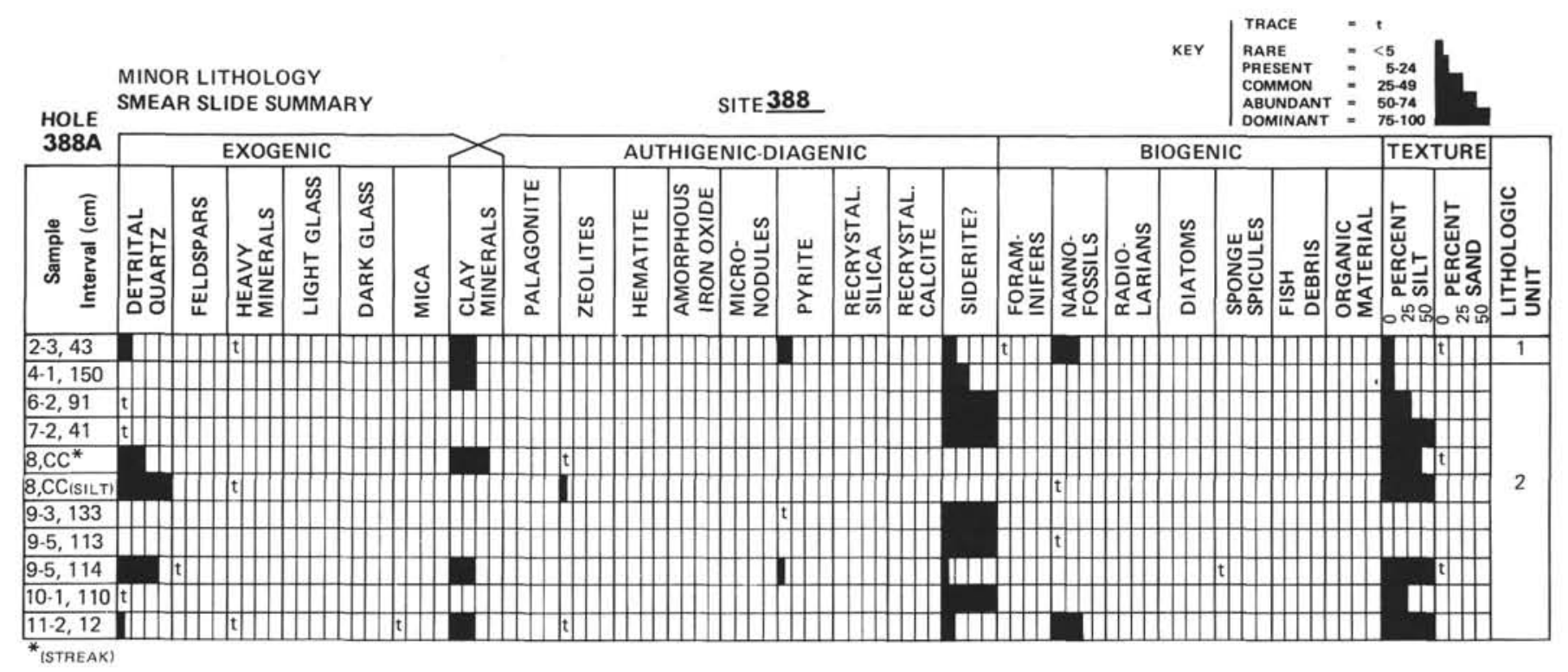

Figure 9. Estimate of major components in minor lithologies from smear slides, Hole $388 \mathrm{~A}$.

TABLE 3

Average Composition of Fine-Grained Sediments of Unit 1 Determined from Smear Slides (8 Slides)

\begin{tabular}{lc}
\hline Clay & $56 \%(46 \%-81 \%)$ \\
Quartz & $18 \%(4 \%-20 \%)$ \\
Carbonate (nannofossils) & $22 \%$ \\
Carbonate (unspecified) & $3 \%$ \\
Mica, heavy minerals, large foraminifers, and & Less than 1\% each \\
$\quad$ sponge spicules & \\
\hline
\end{tabular}

( $40 \%$, including $25 \%$ of pyrite), horblende $(28 \%)$, clinopyroxene $(9 \%)$, orthopyroxene $(4 \%)$, garnet $(5 \%)$, apatite $(3 \%)$, with minor amounts of peridot, sphene, spinel, tourmaline, zircon, anatase, and andalusite.

The iron content ranges from 3.8 to 4.43 per cent; the higher value was obtained from brown calcareous clay. Titanium contents are rather high and range from 0.43 to 0.90 per cent. The manganese content is low $(0.05 \%$ to $0.07 \%$ ) as is common in the hemipelagic sediments. The $\mathrm{CaCO}_{3}$ content ranges from 2 to 39 per cent and organic carbon from 0.1 to 0.4 per cent (average of $0.2 \%$ is relatively low). (See Appendix I, this volume, for organic carbon and carbonate determinations.)

The lower boundary of unit 1 and the upper boundary of unit 2 lie somewhere between Cores 3 and 4 (between 53.5 and $208.0 \mathrm{~m}$ sub-bottom depth).

\section{Unit 2}

Unit 2 represents the upper Tertiary hemipelagic clay and silty clay that is known to be widespread over the continental rise and abyssal basin areas of the western North Atlantic Ocean. In Hole 388A it is very similar to that encountered at DSDP Sites 101, 105, and 106 (Leg 11). Only a part of this thick sequence was cored at Site 388, where it is middle to upper Miocene. The minimum (cored) thickness of unit 2 is 133 meters (between 208 and $341 \mathrm{~m}$ sub-bottom depth). The interval was cored almost continuously, but core recovery was poor and drilling disturbance was extensive in most of the eight cores recovered.

Unit 2 consists entirely of greenish gray (5G4/1 with minor zones of 5GY4/1 in the uppermost part) silty clay and clay. The clay content ranges from 71 to 84 per cent (on basis of 12 samples, see Appendix II, this volume) and is virtually uniform throughout unit 2 . Only a slight downhole increase in clay content from 67 to 75 per cent to 72 to 84 per cent leads to transition from silty clay in the upper part to clay in the lower part. The average clay content is 74.8 per cent, silt ranges from 15.7 to 33.3 per cent (average $24.8 \%$ ), and sand ranges from 0.1 to 2.1 per cent.

The clay is moderately compact in the upper part of unit 2 (Cores 4 through 7) and is slightly more indurated in Cores 5 to 11 . Microscopic fragments of chalcedony were found in Cores 7 and 10.

Common authigenic minerals are pyrite (microspherules and crystals) and siderite(?) (on the basis of smear-slide study). The siderite(?) crystals are in some instances concentrated in soft stringers and in indurated irregular tubes suggestive of burrow fillings. Some indurated tubes are coated with pyrite. We found a $2-3 \mathrm{~cm}$ cone-shaped siderite concretion with the surface sculpture of a "tubotomaculum" burrow in Core 4, Section 1, at $150 \mathrm{~cm}$. Dolomite(?) was probably confused with siderite(?) in some smear slides. "Dolomite" occurs as colorless, low-index $\left(\mathrm{Ne}^{1}=1.57\right)$, "flat"' rhombohedra ranging in size from 2 to $40 \mu \mathrm{m}$. "Siderite" occurs as pale greenish yellow to moderate greenish yellow high-index (No $=1.775, \mathrm{Ne}^{1}$ $>1.60$ ), "blunt" (near cubic) rhombohedra ranging in size from 1 to $10 \mu \mathrm{m}$. "Dolomite" is the dominant rhombic carbonate species in unit 1 ; "siderite" is the dominant rhombic carbonate species in unit 2.

Two mineralogical analyses of the coarse $(<50 \mu \mathrm{m})$ fraction show the quartz content is 40 and 54 per cent, feldspar 12 and 19 per cent. The heavy fraction consists of 
unspecified carbonate (rhodochrosite?) aggregates (42\% to $46 \%$ ) and opaque minerals (40\% and $53 \%$, including $37 \%$ and $52 \%$ oxidized pyrite). Trace quantities of hornblende, clinopyroxene, chlorite, zircon, and barite were found. The iron content is slightly higher in unit $2(4.04 \%$ to $4.57 \%)$ than in unit 1 , titanium contents are lower $(0.42$ to $0.50 \%)$, and $\mathrm{Mn}$ ranges from 0.04 to $0.12 \%$. The $\mathrm{CaCO}_{3}$ content is low throughout unit $2(0 \%$ to $4 \%$, average $1.3 \%)$, but the organic carbon content is higher here than in unit $1(0.3 \%$ to $0.6 \%$, average $0.36 \%$ ) (Appendix I, this volume). The changes in chemical composition correspond with changes in grain size; the higher clay fraction correlates with an increase in iron and organic carbon and with decrease in titanium.

Faint to distinct mottling occurs in unit 2, but it probably originated from chemical diagenesis rather than bioturbation. Thin elongate mottles and stringers that are subparallel to bedding occur throughout the unit. Burrows that cut this crudely laminated fabric are present in some intervals. Very thin (less than $1 \mathrm{~mm}$ ) lenses and streaks of white well-sorted quartzose silt occur in Sample 8, CC, suggestive of disaggregated agglutinated tests.

\section{Discussion}

Two stages in the history of the lower continental rise hills were recognized in sediments from Site 388. Rapid deposition of hemipelagic sediments occurred during the late Tertiary, as has previously been recognized at several sites in the western North Atlantic Ocean. Sedimentation at Site 388 was very similar to that at Site 106 (DSDP Leg 11), which was drilled on the upper continental rise. The sediment accumulation rate at Site 388 was between 20 and $45 \mathrm{~m} / \mathrm{m}$.y. (average $\sim 30 \mathrm{~m} / \mathrm{m}$.y.); this is comparable with accumulation rate at Site $106(43 \mathrm{~m} / \mathrm{m} . \mathrm{y}$.$) . A large supply$ of clay and fine silt from the North American continent obviously existed during this time. Contribution from pelagic organisms, which was minor, consisted almost entirely of calcareous nannofossils. Siliceous remains are extremely rare (except for sponge spicules in Core 9), reflecting an environment of low biogenic productivity. Reducing conditions within the sediments were conducive to the formation of pyrite, dolomite(?), and siderite(?). Indurated clays in the lower part of unit 2 (middle Miocene) have lower water contents and higher wet bulk densities (see Physical Properties, this chapter). Overburden pressure may be a simple explanation for this dewatering.

The Pleistocene was a time of widespread turbidite deposition in the western North Atlantic. Coarse terrigenous sediment was transported from the continental shelf and slope and deposited in depressions on the continental rise. Most of the sediments cored at this site, however, are very fine grained. The high sediment accumulation rate $(\sim 60$ $\mathrm{m} / \mathrm{m} . \mathrm{y}$.) recorded in the Pleistocene suggests turbidity-current or contour-current deposition. The relatively abundant nannofossils in the fine-grained interbeds suggest accumulation above the carbonate compensation depth; however, foraminifers are rare and show some signs of dissolution (see Biostratigraphy, this chapter).

\section{GEOCHEMISTRY}

\section{Introduction}

The geochemistry program at Site 388 had three objectives: (1) to use the high-pressure core barrel to test for the presence of gas clathrates in the upper 300 meters of the sedimentary column, (2) to extensively sample the clathrate-bearing sediments and the Cretaceous "black clay" for geochemical study, and (3) to analyze the interstitial water, squeezed from the soft sediments, for major ions, salinity, $\mathrm{pH}$, and chlorinity.

\section{Gas Clathrates}

Gas clathrates are solid substances composed of gases (such as methane or ethane) and water which are stable at specific temperatures and pressures. Conditions suitable for their presence exist within vast areas of deep-sea sediments. Their presence may influence geological processes, or chemical diffusion and seismic velocities properties. Their existence, however, in marine sediments has not been proven. (For a more detailed discussion of gas clathrates see Kaplan, 1974.)

A high-pressure core barrel (PCB) was designed by the DSDP engineering department and used at Site 388 in an attempt to demonstrate the presence of gas clathrates in marine sediments. Three parameters must be measured when testing for clathrates in the PCB: (1) pressure, which requires a gauge capable of accurate readings between 0 and 10,000 psi, (2) temperature, which must be carefully controlled, and (3) gas volume, which is measured as the gas is released. During Leg 44, we constructed a trough ( $1 \mathrm{ft}$ $\times 32 \mathrm{ft}$ ) to maintain the core from the PCB in an ice bath $\left(0^{\circ} \mathrm{C}\right)$. This would allow us to measure the pressure at constant temperature, keep the clathrate equilibrium pressure at a safe level $\left(400 \mathrm{psi}\right.$ at $\left.0^{\circ} \mathrm{C}\right)$, and require less clathrate decomposition to reach equilibrium pressure than if higher temperatures were used. The measurement of gas volume can be obtained by simple water displacement in a plastic carboy ( $5 \mathrm{gal}$ ) overturned in a water tub; water tub temperature can be used to correct gas volume to STP conditions. Only by knowing temperature, pressure, and gas volume will an unequivocal demonstration of the presence of gas clathrates be performed.

Unfortunately, two attempts with the PCB were unsuccessful owing to instrument failure. The major problem appeared to be the ball assembly which failed to close in either attempt, thereby preventing maintenance of in situ pressure. A second problem was that the stiff sediment did not penetrate more than a few centimeters into the narrow nose of the PCB. This, however, was remedied by use of an extended core cutter in the second attempt, and a core approximately 5 meters long was recovered.

\section{Organic Geochemistry}

Three samples for organic geochemistry were taken from Cores 6 and 7, which may be clathrate-bearing sediments. An additional sample was collected from Core 11. Gas chromatography determinations were conducted on board with a Carle basic gas chromatograph and values of methane, ethane, and methane:ethane ratios are shown in 
Table 4. Methane:ethane ratios are low when compared to ratios at other deep-water sites. This may reflect the preferential loss of methane between coring and sampling of the gas since gas pockets were not evident until approximately one hour after collection.

Mechanical difficulties (see Operations) prevented our drilling beyond Miocene sediments at Site 388 and samples of the Cretaceous black muds were not obtained.

\section{Interstitial Water (Analyst Victor Sotelo)}

We analyzed interstitial water of only 3 samples onboard Glomar Challenger. Our methods were those, with minor modification, of Gieskes (1974) and Gieskes and Lawrence (1976). The $p H$, alkalinity, chlorinity, salinity, calcium and magnesium data are presented in Table 5 and Figure 10 . We detect an increase in calcium and decrease in magnesium downhole. This is further indicated by the $\mathrm{Ca} / \mathrm{Mg}$ ratios shown in Figure 11.

\section{PHYSICAL PROPERTIES}

We measured sonic velocity, wet bulk density, water content, and porosity in samples from suitable cores recovered at Site 388 .

Sonic velocities were measured at 26 points with the Hamilton Frame velocimeter following the procedure described by Boyce (1973). (Accuracy of the technique is \pm 2 per cent; precision of the velocimeter was verified with ten repeated measurements of lucite and brass standards.) Velocities were measured on split core sections at 5.0 $\mu \mathrm{sec} / \mathrm{cm}$. All measurements on the Hole $388 \mathrm{~A}$ cores were made approximately parallel to bedding (perpendicular to the long core axis). Sonic velocity data are shown on Table 6.

The sediments at Site 388 are subdivided into two lithologic units: (1) Holocene to Pleistocene terrigenous sand and silty clay to clay with variable amounts of carbonate (0-53.5 m sub-bottom) and (2) dark greenish gray late-middle Miocene hemipelagic clay and silty clay (208.0-341.0 m sub-bottom). The average velocity of unit 1 is $1.55 \mathrm{~km} / \mathrm{sec}$ and that of unit 2 is $1.56 \mathrm{~km} / \mathrm{sec}$. The sonic velocities of the two units are not distinctly different.

Water content is expressed as per cent wet weight of the sample.

$$
\text { Water content }(\%)=\frac{\text { wt. evaporated water }}{\text { wt. wet sediment }} \times 100
$$

We determined the water contents of 20 samples and the data are presented in Table 7 . The average water content for all samples is 34.8 per cent. That of unit 1 is 36.4 per cent and predictably the average water content of the unit 2 clay is lower: 29.6 per cent.

The wet bulk density measurements (wt. wet sediment/vol. wet sediment), made on the same 20 samples are: average unit $1=1.69 \mathrm{~g} / \mathrm{cc}$, average unit $2,1.82 \mathrm{~g} / \mathrm{cc}$, average both units $=1.78 \mathrm{~g} / \mathrm{cc}$ (Table 7).

Porosities (\%) were determined by the following equation. This method assumes that pore space is filled with water.

$$
\% \text { Porosity }=\frac{\text { wt. wet sample }- \text { wt. dry sample }}{\text { volume wet sample }(\text { syringe technique })} \times 100
$$

Because none of the Hole 388A samples were indurated, volume of sample was read directly from the ml-syringe-sampler used to extract the sediment from the core.

The average porosity for the entire sequence is 55.6 per cent. Average porosity of the unit 1 sediments is 61.3 per cent; average porosity of the unit 2 sediments is 53.7 per cent (Table 7).

\section{BIOSTRATIGRAPHY}

\section{Summary}

Hole $388 \mathrm{~A}$ was drilled in deep water $(4920 \mathrm{~m})$ on the lower continental rise hills of the western Atlantic continental margin. Sediment sequences of Pleistocene and middle to upper Miocene were recovered. Two lithologic units are recognized and each is characterized by a different

TABLE 4

Summary of Gas Chromatography, Site 388

\begin{tabular}{cccccc}
\hline $\begin{array}{c}\text { Sample } \\
\text { (Interval } \\
\text { in cm) }\end{array}$ & $\begin{array}{c}\text { Sub- } \\
\text { Bottom } \\
\text { Depth } \\
(\mathrm{m})\end{array}$ & $\begin{array}{c}\text { Methane } \\
\left(\mathrm{CH}_{4}\right) \\
(\mathrm{ppm})\end{array}$ & $\begin{array}{c}\text { Ethane } \\
\mathrm{C}_{2} \mathrm{H}_{6} \\
(\mathrm{ppm})\end{array}$ & $\begin{array}{c}\mathrm{R}^{2} \mathrm{CH}_{4} / \\
\mathrm{C}_{2} \mathrm{H}_{6}\end{array}$ & Remarks \\
\hline $5-6,0-1$ & 254 & 13,000 & N.D. & - & \\
$7-2,0-1$ & 295 & 120,000 & 50 & 2400 & PCB \\
$9-4,0-1$ & 328 & 390,000 & 125 & 3120 & \\
\hline
\end{tabular}

TABLE 5

\begin{tabular}{|c|c|c|c|c|c|c|c|}
\hline Sample & $\begin{array}{l}\text { Sub-Bottom } \\
\text { Depth Top } \\
\text { (m) }\end{array}$ & $p \mathrm{H}$ & $\begin{array}{r}\text { Alkalinity } \\
(\mathrm{meg} / \mathrm{kg})\end{array}$ & $\begin{array}{c}\text { Salinity } \\
(\mathrm{o} / 00)\end{array}$ & $\underset{(\mathrm{mmoles} / \mathrm{l})}{\mathrm{Ca}^{++}}$ & $\underset{(\mathrm{mmoles} / \mathrm{l})}{\mathrm{mg}^{++}}$ & $\begin{array}{c}\mathrm{Cl}^{-} \\
(\mathrm{o} / \mathrm{oo})\end{array}$ \\
\hline $\begin{array}{l}\text { IAPSO } \\
\text { STD sea }\end{array}$ & - & 7.88 & 2.37 & 35.2 & - & - & - \\
\hline $\begin{array}{l}\text { IAPSO } \\
\text { STD sea }\end{array}$ & - & 8.04 & 2.34 & 35.2 & - & - & - \\
\hline $\begin{array}{l}\text { Surface } \\
\text { Seawater }\end{array}$ & - & 8.37 & 2.38 & 36.3 & 11.1 & 55.0 & 19.7 \\
\hline $\begin{array}{l}2-2,140-150 \\
5-2,140-150 \\
9-4,140-150\end{array}$ & $\begin{array}{r}40.2 \\
249.2 \\
318.7\end{array}$ & $\begin{array}{l}7.85 \\
8.34 \\
8.12\end{array}$ & $\begin{array}{l}5.53 \\
5.66 \\
7.25\end{array}$ & $\begin{array}{l}34.1 \\
34.1 \\
34.1\end{array}$ & $\begin{array}{l}12.5 \\
15.2 \\
17.6\end{array}$ & $\begin{array}{l}39.9 \\
35.3 \\
33.1\end{array}$ & $\begin{array}{l}19.0 \\
19.5 \\
19.7\end{array}$ \\
\hline
\end{tabular}

Summary of Interstitial Water Data, Hole 388A 


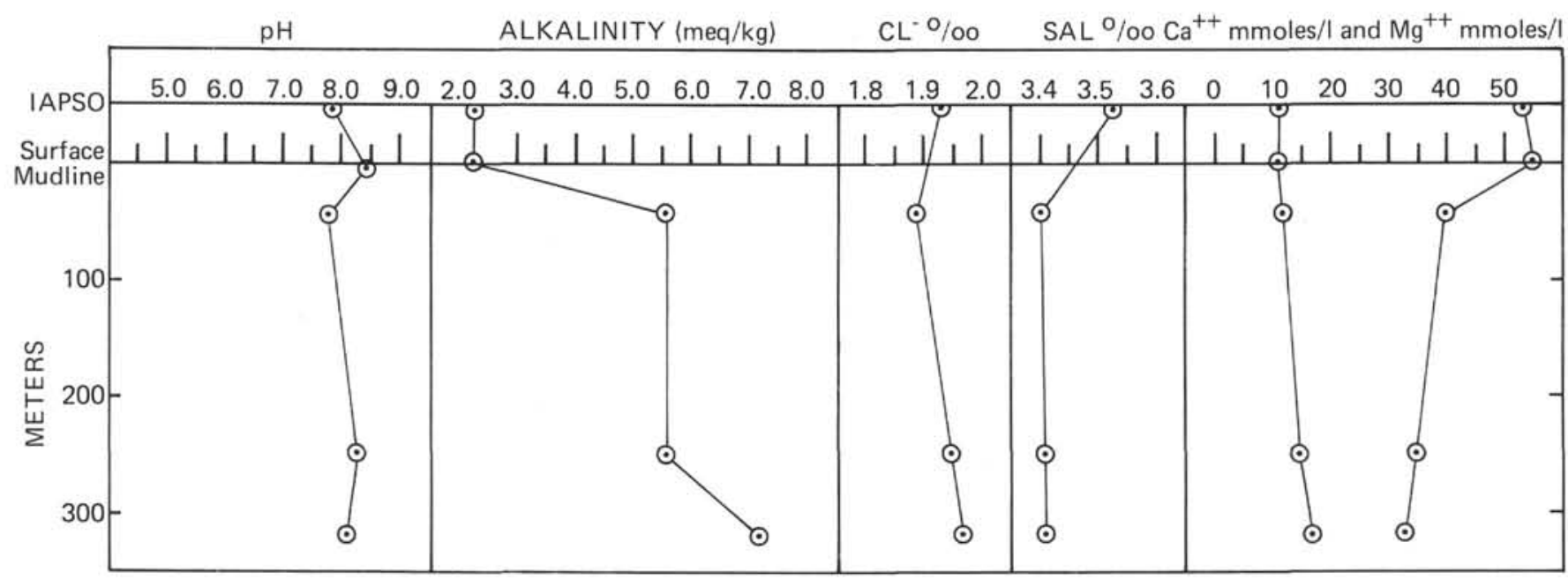

Figure 10. Interstitial water data, Hole $388 \mathrm{~A}$.

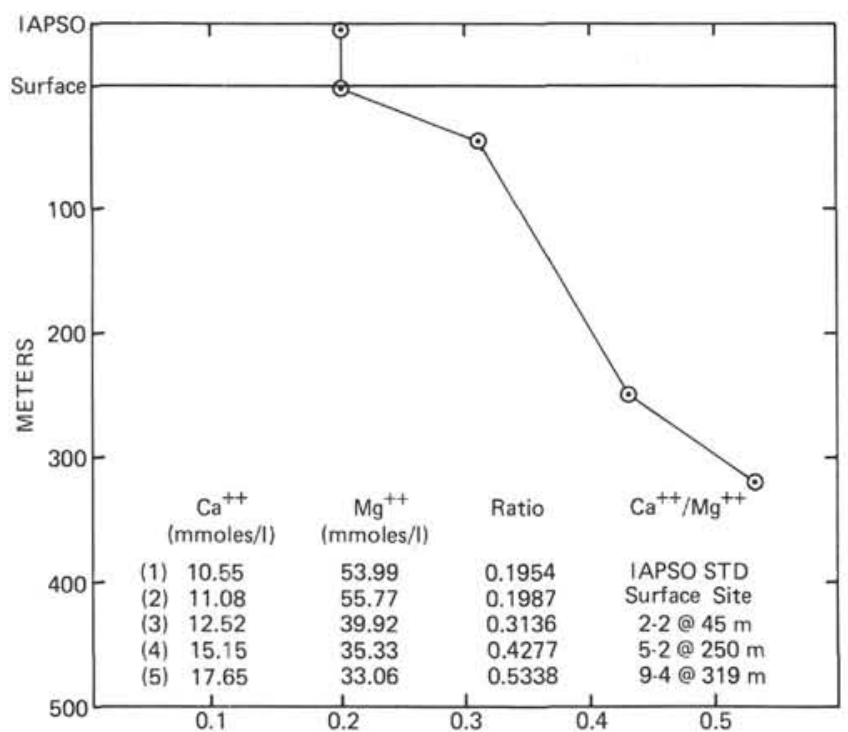

Figure 11. Ca/Mg ratio versus depth, Hole $388 \mathrm{~A}$.

microfossil record. A summary of the biostratigraphic results is presented in Figure 12.

\section{Unit 1 (Cores 1-3, thickness $53.5 \mathrm{~m}$ )}

Unit 1 consists of nannofossil-foraminifer clay in association with terrigenous sands and silt. Pleistocene planktonic foraminifers and calcareous nannofossils are abundant and well preserved in every sample examined. Some reworked species were encountered in unit 1; particularly notable is a large suite of Upper Cretaceous nannofossils and moderately well preserved Miocene and Eocene radiolarians. The reworked microfossils probably are derived from nearby outcrops along the continental slope and displaced by bottom and/or turbidity currents into sediments accumulating at Hole 388A.

\section{Unit 2 (Cores 4-11, thickness $123.5 \mathrm{~m}$ )}

A 145-meter uncored interval separates units 1 and 2 . Unit 2 consists of slightly calcareous hemipelagic clay and silty clay. The nannofossil and planktonic foraminifer associations within the unit indicate that they were near the carbonate compensation depth (CCD). Generally, only thick-shelled species of planktonic foraminifers are preserved, and specimens are greatly fragmented or etched. The discoaster/coccolith ratio, which increases as the CCD is approached (Bukry, 1973), is very high within Cores 4 to 11. Coccoliths are sparse and are commonly etched and fragmented. We determined the age for this unit on the basis of successive assemblages of discoasters as recognized in the standard zonation (NN 9-NN 11) for tropical subtropical regions. Planktonic foraminifers seem indicative of zones $\mathrm{N}$ 14-N 17, in agreement with the nannofossil zonal assignment. Poorly preserved radiolarians were recovered in Cores 9 and 10, but an age assignment of middle Miocene was only possible from one sample, 388A-9-6, $119-121 \mathrm{~cm}$.

We found some curious fossils of unknown affinity in Core 5, Sections 2 and 3 which are described in more detail below.

\section{Foraminifers}

Eleven core-catcher samples and 27 core samples were studied from Hole 388. All samples, except the core-catcher samples of Cores 1 and 2, were boiled in fresh water with Calgon. Samples from Cores 1 and 2 were processed in $\mathrm{H}_{2} \mathrm{O}_{2}$ and the slides from these samples have many test fragments, possibly resulting from the $\mathrm{H}_{2} \mathrm{O}_{2}$ action on delicate tests.

The Pleistocene cores (Cores 1, 2, and 3) yield a rich planktonic fauna and some benthic species. The (middle-upper Miocene) core-catcher samples (Cores 4 to 11) yield few planktonic and very few benthic foraminifers; foraminifers are virtually absent from the other samples of 
TABLE 6

Sonic Velocity Measurements $(\mathrm{km} / \mathrm{sec})$, Hole 388A

\begin{tabular}{|c|c|c|c|c|}
\hline Sample & $\begin{array}{l}\text { Depth in } \\
\text { Hole } \\
(\mathrm{m})\end{array}$ & $\begin{array}{l}\text { Velocity } \\
(\mathrm{km} / \mathrm{sec})\end{array}$ & $\begin{array}{c}\text { Lithologic } \\
\text { Unit }\end{array}$ & Lithology \\
\hline $2-2,66$ & 39.14 & 1.49 & 1 & Marly nannofossil ooze \\
\hline $2-2,116$ & 39.66 & 1.49 & 1 & Calcareous clay \\
\hline $2-3,57$ & 40.57 & 1.62 & 1 & Calcareous silty clay \\
\hline $2-3,126$ & 41.26 & 1.60 & 1 & Calcareous silty clay \\
\hline $5-2,35$ & 248.35 & 1.55 & 2 & Dark greenish gray clay \\
\hline $5-2,81$ & 248.81 & 1.55 & 2 & Dark greenish gray clay \\
\hline $5-2,109.5$ & 249.10 & 1.57 & 2 & Dark greenish gray clay \\
\hline $5-4,62.5$ & 251.63 & 1.60 & 2 & $\begin{array}{l}\text { Dark greenish gray clay } \\
\text { (disturbed) }\end{array}$ \\
\hline $5-4,121$ & 252.21 & 1.56 & 2 & $\begin{array}{l}\text { Dark greenish gray clay } \\
\text { (disturbed) }\end{array}$ \\
\hline $5-6,41.5$ & 254.42 & 1.55 & 2 & $\begin{array}{l}\text { Dark greenish gray silty } \\
\text { clay (highly disturbed) }\end{array}$ \\
\hline $5-6,96$ & 254.96 & 1.54 & 2 & $\begin{array}{l}\text { Dark greenish gray silty } \\
\text { clay (highly disturbed) }\end{array}$ \\
\hline $5-6,140$ & 255.40 & 1.54 & 2 & $\begin{array}{l}\text { Dark greenish gray silty } \\
\text { clay (highly disturbed) }\end{array}$ \\
\hline $6-1,137$ & 285.37 & 1.99 & 2 & $\begin{array}{l}\text { Dark greenish gray stiff } \\
\text { clay }\end{array}$ \\
\hline $8-1,73$ & 303.73 & 1.93 & 2 & $\begin{array}{l}\text { Dark greenish gray very } \\
\text { stiff clay }\end{array}$ \\
\hline $9-3,22$ & 315.72 & 1.49 & 2 & $\begin{array}{l}\text { Dark greenish gray very } \\
\text { stiff clay }\end{array}$ \\
\hline $9-3,123$ & 316.73 & 1.49 & 2 & $\begin{array}{l}\text { Dark greenish gray very } \\
\text { stiff clay }\end{array}$ \\
\hline $9-4,25$ & 317.25 & 1.60 & 2 & $\begin{array}{l}\text { Dark greenish gray very } \\
\text { stiff clay }\end{array}$ \\
\hline $9-4,125$ & 318.25 & 1.43 & 2 & $\begin{array}{l}\text { Dark greenish gray very } \\
\text { stiff clay }\end{array}$ \\
\hline $9-5,56$ & 319.06 & 1.12 & 2 & $\begin{array}{l}\text { Dark greenish gray very } \\
\text { stiff clay }\end{array}$ \\
\hline $9-5,102$ & 319.52 & 1.61 & 2 & $\begin{array}{l}\text { Dark greenish gray very } \\
\text { stiff clay }\end{array}$ \\
\hline $10-1,137$ & 323.37 & 1.65 & 2 & $\begin{array}{l}\text { Dark greenish gray stiff } \\
\text { clay and slurry }\end{array}$ \\
\hline $10-1,144$ & 323.44 & 1.64 & 2 & $\begin{array}{l}\text { Dark greenish gray stiff } \\
\text { clay and slurry }\end{array}$ \\
\hline $11-2,22$ & 333.72 & 1.52 & 2 & $\begin{array}{l}\text { Dark greenish gray stiff } \\
\text { and soft clay fragments } \\
\text { (highly disturbed) }\end{array}$ \\
\hline $11-2,96$ & 334.46 & 1.41 & 2 & $\begin{array}{l}\text { Dark greenish gray stiff } \\
\text { and soft clay fragments } \\
\text { (highly disturbed) }\end{array}$ \\
\hline $11-5,19$ & 338.19 & 1.52 & 2 & $\begin{array}{l}\text { Dark greenish gray clay } \\
\text { (disturbed) }\end{array}$ \\
\hline $11-5,69$ & 338.69 & 1.54 & 2 & $\begin{array}{l}\text { Dark greenish gray clay } \\
\text { (disturbed) }\end{array}$ \\
\hline
\end{tabular}

Note: All measurements made in core liner and parallel to bedding.

these cores. The low number of specimens is most likely a result of dissolution at depth, coupled with the generally small volume of the samples. Many species may have been dissolved at considerably shallower depths than those at which the most resistant species are dissolved. Through this process, several Miocene index species were apparently removed from the original assemblages, and consequently the Miocene zonation is poorly defined and somewhat tentative. A distribution chart of selected planktonic taxa found in the Hole 388A samples is given in Figure 13.

\section{Pleistocene}

Cores 1, 2, and 3 contain intervals of detrital and planktonic foraminifer ooze. The fauna indicates a Pleistocene age ( $G$. truncatulinoides Zone, N.22), and reflects deposition in "warmer" water. Exceptions are
Samples 1-1, 105-107 cm, and 2-3, 104-106 cm, with few or no keeled globorotaliids, suggesting deposition in "colder, glacial"' times.

\section{Planktonic Foraminifers}

The following species were recognized (see also Figure 13): Globorotalia truncatulinoides (mostly right coiling), $G$. crassaformis, $G$. hirsuta, $G$. tumida group, $G$. menardii group, $G$. inflataforma A and B, Globigerina dutertrei, $G$. aff. pachyderma, Orbulina universa, Globigerinoides ruber (pink), G. sacculifera, G. extremus, G. trilobus, $G$. conglobatus, Pulleniatina obliquiloculata, Sphaeroidinella dehiscens.

Following Blow (1967), Lamb and Beard (1972), and Poag (1972), we assign the planktonic foraminifer assemblage to the Pleistocene (N.22, G. truncatulinoides Zone). The most important criteria for this zonal assignment are the presence of right-coiling $G$. truncatulinoides, few big $G$. tumida group, no $G$. calida and no $S$. dehiscens excavata.

\section{Benthic Foraminifers}

Core-catcher samples from Cores 1, 2, and 3 contain a number of benthic species. Following Phleger et al. (1953), the following taxa were recognized: Uvigerina hollicki, Angulogerina sp., Nonion pompilioides, Nonion sp., Cibicides wuellerstorfi, Cibicides spp., Eggerella bradyi, Textularia australis, Gyroidina sp., Eponides umbonatus, "Rotalia" praegeri, Bulimina sp., Pyrgo sp., Dorothia sp.

Some of these taxa may have lived in shallower water which might explain the variation in their preservation. Specimens could have been reworked from the U.S. continental slope or shelf. The presence of numerous reworked radiolarians (see below) also indicates redeposition of fossils at this site (see also below, Dissolution of Calcareous Microfossils).

\section{Tertiary}

Cores 4 to 6 contain few specimens and few zonal markers; thus the zonation is less detailed than that in low latitude assemblages.

Cores 4 to 6 are assigned to the upper Miocene Zones N.16-N.17; the fauna from Cores 9 to 11 suggest upper middle Miocene-lower upper Miocene zones N.14-N.15. Core-catcher samples from Cores 4 and 5 contain isolated specimens of $G$. inflata and $G$. crassaformis, here interpreted as cavings. Cores 7 and 8 contain a fauna characteristic of upper Miocene-lower Pliocene strata; nannofossils indicate upper Miocene sediments at this depth.

\section{Planktonic Foraminifers}

In Cores 4,5 , and 6 the following species were recognized: Globorotalia tumida group, and G. menardii group, G. pseudomiocenica, G. acostaensis, Globigerina nepenthes, $G$. bulloides, Globigerinoides spp., 
TABLE 7

Water Content, Porosity, and Wet Bulk Density, Hole 388A

\begin{tabular}{|c|c|c|c|c|c|c|}
\hline Sample & $\begin{array}{l}\text { Depth in } \\
\text { Hole } \\
\text { (M) }\end{array}$ & $\begin{array}{l}\text { Water Content } \\
(\%)\end{array}$ & $\begin{array}{l}\text { Wet Bulk Density } \\
(\mathrm{g} / \mathrm{cc})\end{array}$ & $\begin{array}{l}\text { Porosity } \\
(\%)\end{array}$ & $\begin{array}{l}\text { Lithologic } \\
\text { Unit }\end{array}$ & Lithology \\
\hline $1-1,98.5$ & 0.99 & 41.5 & 1.61 & 66.7 & 1 & Calcareous silty clay and sand \\
\hline $1-3,21.5$ & 3.22 & 41.5 & 1.60 & 66.5 & 1 & Marly nannofossil ooze \\
\hline $1-4,5.5$ & 4.55 & 34.2 & 1.73 & 59.1 & 1 & Sand and calcareous silty clay \\
\hline \multicolumn{2}{|c|}{ Core 1 averages } & 39.1 & 1.65 & 64.1 & & \\
\hline $2-2,29.5$ & 38.80 & 31 & 1.79 & 55.5 & 1 & Calcareous (nannofossil) clay \\
\hline $2-3,27.5$ & 40.28 & 34 & 1.73 & 58.9 & 1 & Calcareous silty clay \\
\hline \multicolumn{2}{|c|}{ Core 2 averages } & 32.5 & 1.76 & 57.2 & & \\
\hline $4-1,96.5$ & 208.97 & 39.6 & 1.66 & 65.6 & 2 & Silty clay \\
\hline $5-1,29.5$ & 246.80 & 27.4 & 1.86 & 51 & 2 & Dark greenish gray clay \\
\hline $5-2,30.5$ & 248.31 & 30.6 & 2.04 & 62.5 & 2 & Dark greenish gray clay \\
\hline $5-4,46.5$ & 251.47 & 32.6 & 1.81 & 59.2 & 2 & Dark greenish gray clay (disturbed) \\
\hline $5-5,29.5$ & 252.80 & 31.2 & 1.84 & 57.4 & 2 & $\begin{array}{l}\text { Dark greenish gray silty clay (highly } \\
\text { disturbed) }\end{array}$ \\
\hline \multicolumn{2}{|c|}{ Core 5 averages } & 30.4 & 1.89 & 57.5 & & \\
\hline $6-2,100.5$ & 286.51 & 27.2 & 1.90 & 51.5 & 2 & Dark greenish gray stiff clay \\
\hline $7-2,39.5$ & 295.39 & 29.0 & 1.72 & 49.8 & 2 & Dark greenish gray stiff clay \\
\hline $7-3,37.5$ & 296.88 & 29.4 & 1.98 & 58.5 & 2 & Dark greenish gray stiff clay \\
\hline \multicolumn{2}{|c|}{ Core 7 averages } & 29.2 & 1.85 & 54.2 & & \\
\hline $8-1,64.5$ & 303.64 & 26.3 & 1.97 & 51.7 & 2 & Dark greenish gray very stiff clay \\
\hline $9-1,22.5$ & 312.72 & 27.4 & 1.82 & 49.7 & 2 & Dark greenish gray very stiff clay \\
\hline $9-3,33.5$ & 315.84 & 29.6 & 1.58 & 46.8 & 2 & Dark greenish gray very stiff clay \\
\hline $9-4,34.5$ & 317.35 & 29 & 1.52 & 43.9 & 2 & Dark greenish gray very stiff clay \\
\hline $9-5,80.5$ & 319.31 & 28.6 & 1.96 & 56.2 & 2 & Dark greenish gray very stiff clay \\
\hline $9-6,114.5$ & 321.14 & 28.9 & 1.74 & 50.2 & 2 & Dark greenish gray very stiff clay \\
\hline \multicolumn{2}{|c|}{ Core 9 averages } & 28.7 & 1.72 & 49.4 & & \\
\hline $10-1,133.5$ & 323.34 & 28 & 1.84 & 51.3 & 2 & $\begin{array}{l}\text { Dark greenish gray stiff clay and } \\
\text { slurry. }\end{array}$ \\
\hline
\end{tabular}

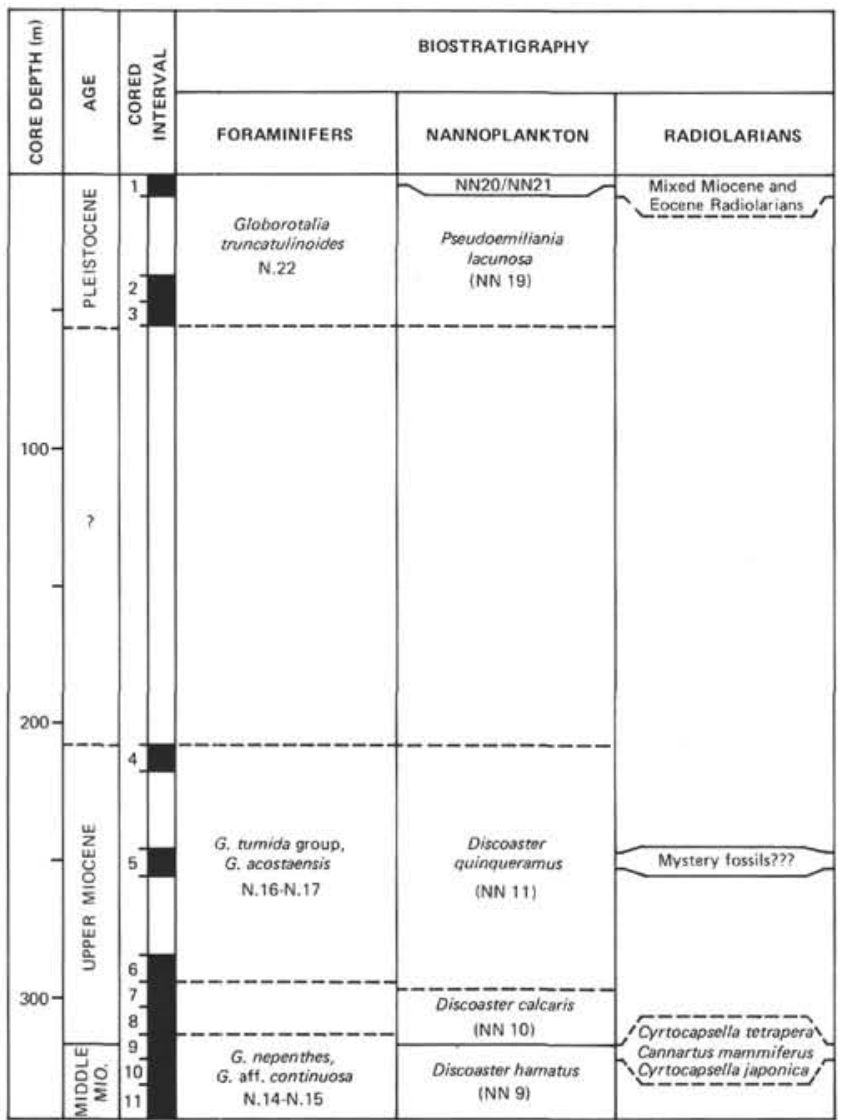

Figure 12. Biostratigraphic summary, Hole 388A, lower continental rise hills.
Globoquadrina altispira, G. dehiscens, Sphaeroidinella seminulina.

The presence of some specimens of $G$. acostaensis, together with $G$. tumida group, G. pseudomiocenica, and $G$. nepenthes and the exclusively Pliocene taxa indicates zones N.16-N.17, upper Miocene.

In Cores 9 to 11 occur: Globorotalia menardii group, $G$. aff. continuosa, G. miozea group, Globigerina nepenthes, $G$. aff. nepenthes (?druri), Globigerinita naparimaensis (surprisingly common for such a small, delicate form), Hastigerina aff. aequilateralis, Sphaeroidinella subdehiscens, Globoquadrina dehiscens, S. seminula, Globigerina apertura, G. aff. pachyderma, Orbulina universa, $O$. bilobata, Globigerinoides trilobus, $G$. immaturus, $G$. obliquus.

The presence of $G$. nepenthes indicates zone N.14 or younger. The presence of $G$. aff. continuosa and the absence of $G$. tumida group and $G$. acostaensis suggest zones N.14-N.15, upper middle Miocene-lower upper Miocene. Nannofossils indicate that the cores largely belong to the upper part of the middle Miocene.

\section{Nannoplankton}

The 11 cores of Hole 388A contain Quaternary and middle-upper Miocene species assemblages.

Samples from the calcareous clay, sand, and silt of unit 1 (Cores 1-3) contain abundant and well-preserved nannofossils. Reworked nannoplankton also occur in these samples, which is consistent with the view that unit 1 is a turbidite sequence. Well-preserved Upper Cretaceous species are prevalent, along with a smaller number of poorly preserved Tertiary species. 


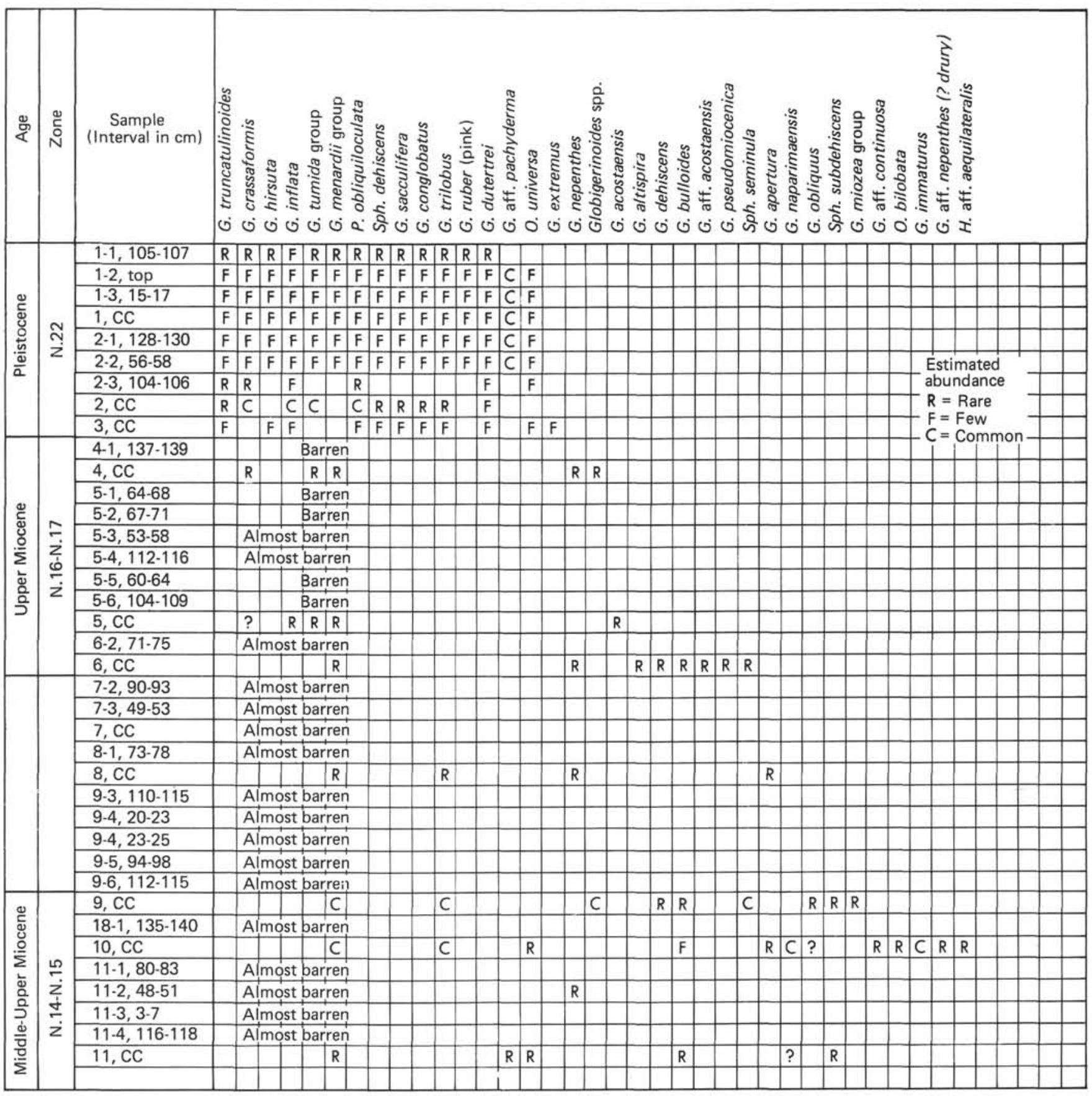

Figure 13. Distribution of selected foraminifers, Hole $388 \mathrm{~A}$.

Section 1 of Core $388 \mathrm{~A}-1$ is assigned to the combined Gephyrocapsa oceanica/Emiliania huxleyi zonal interval (NN 20/21) on the basis of the presence of abundant $G$. oceanica and the absence of Pseudoemiliania lacunosa. The core/catcher samples of Cores 1-3 are assigned to the underlying Pseudoemiliania lacunosa Zone (NN 19).

Cores 4 to 11 penetrated middle-upper Miocene hemipelagic clay of unit 2. (Core 4 is separated from Core 3 by 144.5 meters of undrilled sediment.) All samples were deposited close to the carbonate compensation depth and many were barren of nannoplankton. Those samples containing nannofossils have a high discoaster/coccolith ratio and the coccoliths present are often etched and fragmented. The index species for the Discoaster quinqueramus Zone (NN 11), the D. calcaris Zone (NN 10 ), and the Discoaster hamatus Zone (NN 9), however, were recognized in succession. Cores 4 and 6 contain the restricted index species for the Discoaster quinqueramus Zone (NN 11) indicating upper Miocene sediments. Cores 7,8 , and the top of $9(9-3,116 \mathrm{~cm})$ are assigned to the upper/middle Miocene Discoaster calcaris Zone (NN 10). The bottoms of Cores 9,10 , and 11 contain discoasters of the Discoaster hamatus Zone (NN 9) assigned to the middle Miocene. 


\section{Radiolarians}

Poorly to moderately well preserved radiolarians were found in Cores 1,9 , and 10 of Hole 388A. All remaining cores examined were totally barren of siliceous microfossils.

Sample 388A-1, CC, contains a moderately well to well-preserved diverse assemblage of mixed middle to lower Miocene and Eocene radiolarians (Figure 14). Since diagnostic Pleistocene calcareous foraminifers and nannofossils were common throughout Core 1 , the radiolarians in Sample 388A-1, CC were obviously winnowed from submarine outcrops along the continental slope or rise and redeposited in ponded turbidites accumulating between the continental rise hills. The well-preserved condition of radiolarians in Sample 388A-1, $\mathrm{CC}$ indicates that they were transported only short distances by currents and thus the outcrop source was nearby.

Sample 388A-9-5, 102-104 cm contains only a few fragments of Orosphaerid spines and undiagnostic spumellarians; however, Sample 388A-9-6, 119-121 cm

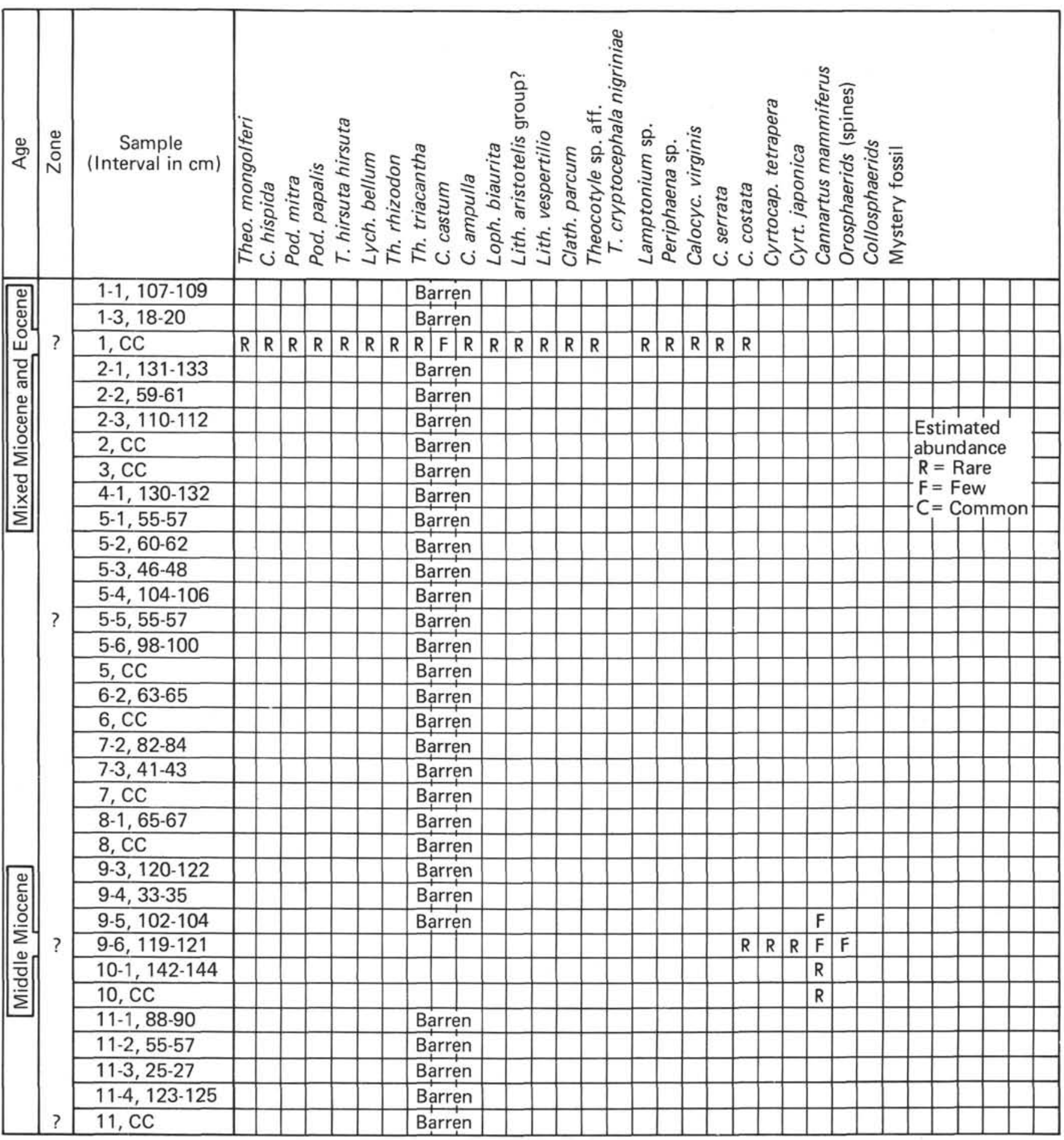

Figure 14. Distribution of radiolarians, Hole $388 \mathrm{~A}$. 
contains a poorly preserved, yet more diverse, radiolarian assemblage diagnostic of middle Miocene sediments (Figure 14). Most radiolarians found in Section 388A-9-6 are fragmented indicating that they were reworked to some degree. The abundance of Orosphaerid and Collosphaerid radiolarians (tropical to subtropical forms) in Core 9 suggests that a warm climate prevailed at Site 388 during the middle Miocene.

Samples 388A-10-1, and 10, CC contain only digitate spines of Orosphaerid radiolarians, thus no age determination on the basis of radiolarians was possible.

\section{Mystery Fossils}

Two samples, 388A-5-3, 46-48 cm, and 5-2, 60-62 cm, from the upper Miocene contain numerous microfossils of an unknown affinity (Figure 15). These microfossils were found during routine examination of the acid $(\mathrm{HCl})$ residue fraction greater than $63 \mu \mathrm{m}$. They are between 63 and 150 $\mu \mathrm{m}$ in size and are composed of some type of organic substance, possibly chitin. Basically, these specimens consist of a thick, sometimes hollow spherical to elliptical, central test which contains one or more tubular, sub-cylindrical, or cone-shaped extended collars (Figure 15). They are not the chitinous inner linings often found in some foraminifer genera. Most tests have multiple collars
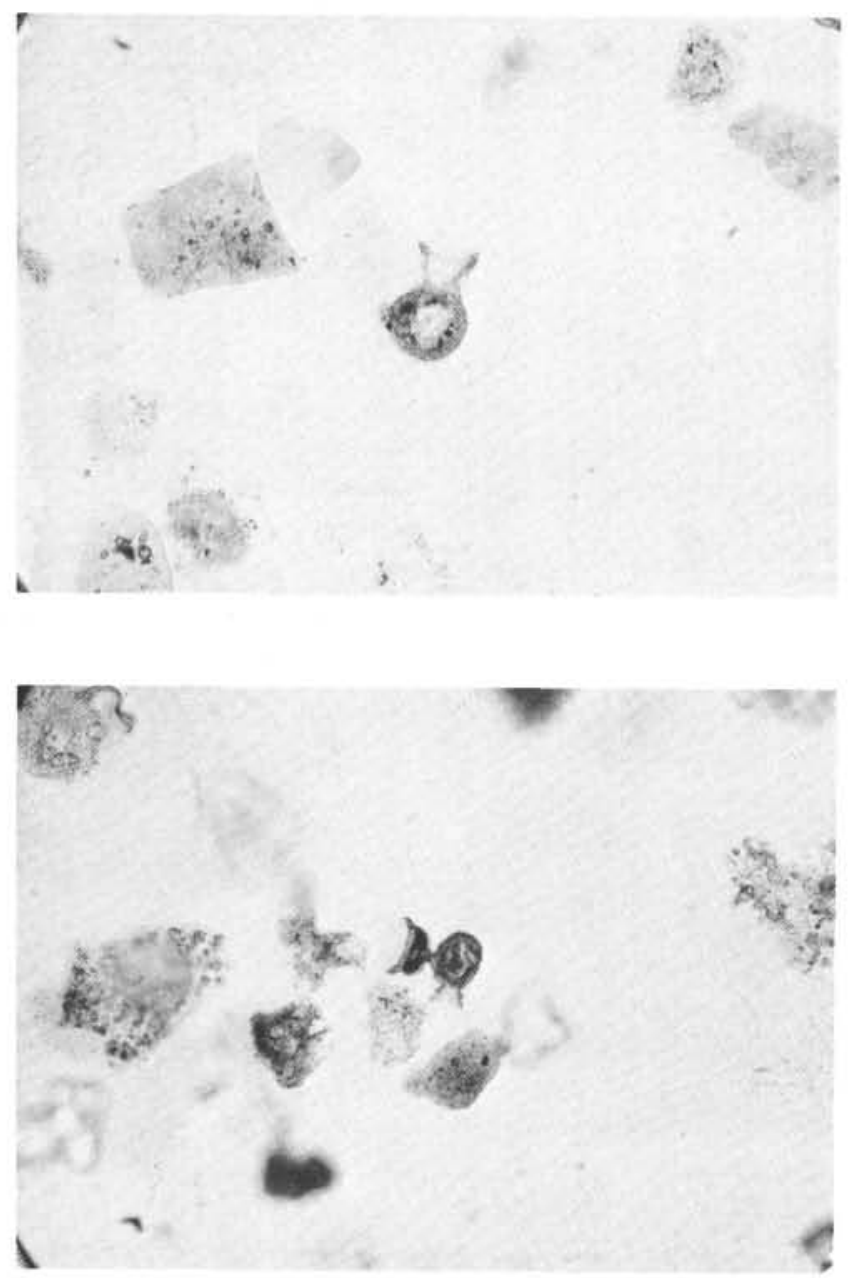

and occasional protuberances which would probably exclude the possibility of their being tintinnids; however, their flask-like shape does closely resemble that of Paleozoic chitinozoans. We could reasonably expect that continentally derived Paleozoic microfossils be encountered in Neogene sediments in the North Atlantic. Needham et al. (1969) have found carboniferous palynomorphs within marine sediments along the continental margin and have used them as tracers of sediment dispersal patterns. In the Canadian Atlantic shelf subsurface, a wide range of Paleozoic-Mesozoic microfossils with walls of organic substances occur in Upper Cenozoic marine strata.

Perch-Nielsen (1975) described similar microfossils from Eocene to Paleocene sediments of Sites 280 and 283 (Tasman Sea).

\section{Dissolution of Calcareous Microfossils}

The foraminifer residues from the 38 samples in Hole $388 \mathrm{~A}$ may be classified in two categories on the basis of dissolution of tests.

In cores 1, 2, and 3 planktonic foraminifers are an important constituent of the sediment; preservation is moderate to good. The presence of many broken tests in the core-catcher samples of Cores 1 and 2 may in part be the result of processing in $\mathrm{H}_{2} \mathrm{O}_{2}$ rather than dissolution at depth,
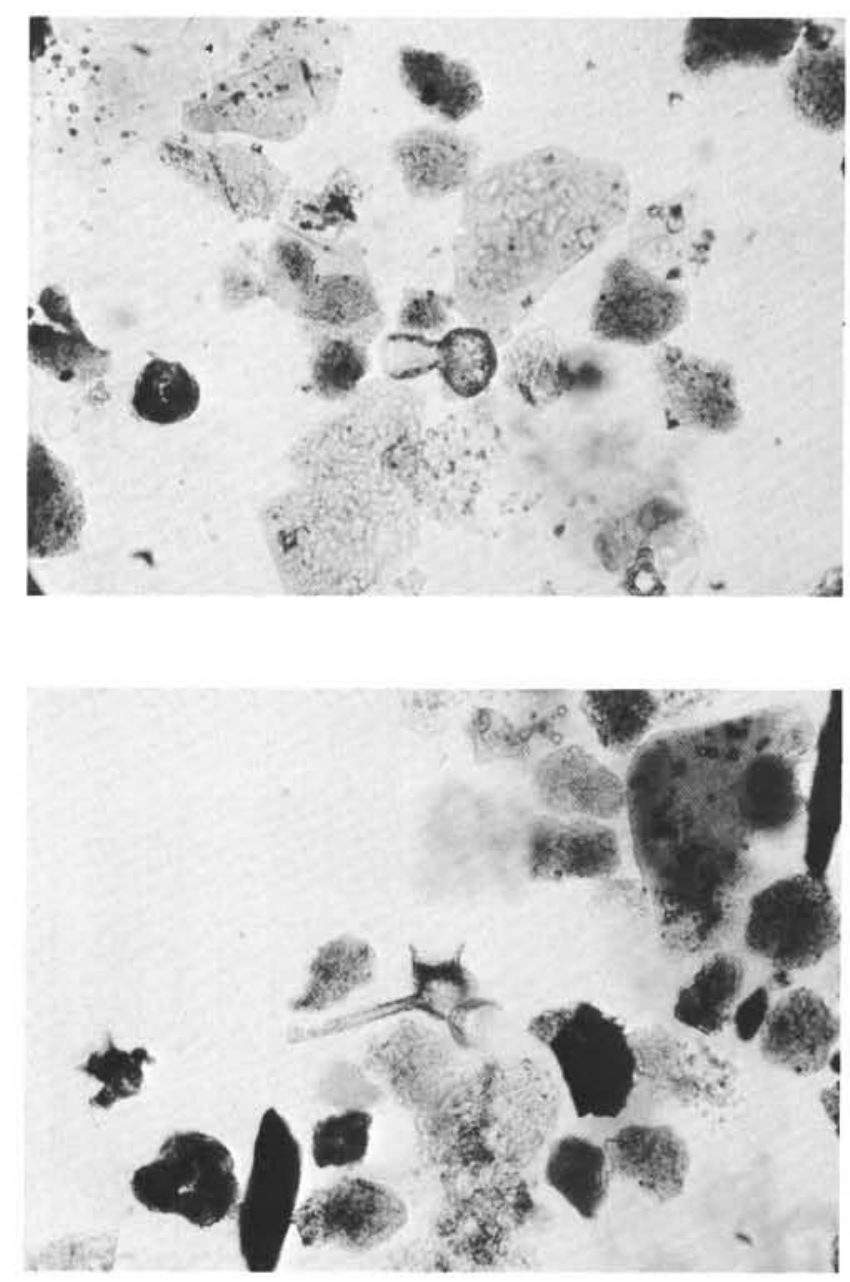

Figure 15. Unidentified microfossils from Hole 388A, Core 5. 
but some dissolution at depth seems to have occurred. A clear example of partial dissolution are the tests of $G$. hirsuta in the core-catcher sample of Core 1. Following the dissolution classification in Maxwell et al., 1970, (p. 452) the sediment is classified as alytic to oligolytic (no signs to some signs of dissolution of calcareous foraminifer shells).

Because of the present depth of the site, at about the lower limit of the CCD for foraminifers (see Figure 4, p. 669 , in Bader et al., 1970), we may speculate that the larger part of the faunas was displaced from shallower depths and rapidly buried. The presence of reworked radiolarians, shallow-watter benthic foraminifers, the clastic nature of the sediments, and the relatively high rate of sedimentation are consistent with this sedimentary pattern.

In Cores 4 to 11 (middle-upper Miocene) foraminifers form a minor constituent of the sediments penetrated; nannofossils as a whole are as abundant as in the overlying strata in Hole 388A. All samples classify as mesolytic (only nannofossils and the more resistant foraminifers) to almost hololytic (no foraminifers, only nannofossils). Since the numbers of nannofossils do not steadily decrease downhole, the site may never have been deeper than about $5 \mathrm{~km}$ (fig. 4, p. 669 in Bader et al., 1970). According to this figure, the middle-upper Miocene foraminifer dissolution depth would have been between 3.5 and $4 \mathrm{~km}$, which is almost 1000 meters shallower than the present site depth. Even if we subtract 341 meters (thickness of sediment in Hole 388A) and assume some eustatic sea level lowering (late Miocene "glaciation"), deposition would have been at considerably shallower depths than that at the present site.

Three possible reasons for the depth discrepancy are: (a) the site subsided maximally 1000 meters since middle Miocene time (not very likely), (b) the figure in Bader (1970) is not applicable to this site (perhaps because of the high carbonate production close to the basin margin), (c) the foraminifer tests present in the samples were redeposited from the slope and buried "rapidly," before dissolution took place (a reasonable possibility in view of the hemipelagic character of the sediment).

\section{SEDIMENT ACCUMULATION RATES}

Sediment accumulation rates calculated for the two distinct lithologies recovered at Hole $388 \mathrm{~A}$ are shown in Figure 16. Sedimentation rates average 4 to $5 \mathrm{~cm} / 1000 \mathrm{yr}$ for the turbidite sequences of lithologic unit 1 (Cores 1-3). We determined these averages on the basis of calculations from Core 1, Section 1 ( $G$. oceanica Zone, E. huxley NN 20/NN 21) the base of Core 3 (P. lacunosa Zone, NN 19).

Lithologic unit 2, a gray to greenish gray hemipelagic clay and silty clay, accumulated at markedly reduced rates. The average rate calculated for the 133 meters of sediment from the top Core 4 through the bottom of Core 11 is 2 to 3 $\mathrm{cm} / 1000 \mathrm{yr}$. Core 4 is within the D. quinqueramus Zone (NN $11, \mathrm{t}=5.5$ to 9.5 m.y.B.P.) while Core 11 is within the D. hamatus Zone (NN 9, $\mathrm{t}=11$ to 12.5 m.y.B.P.).

Obviously the slope of the line representative of sedimentation rates in Figure 16 could be variable owing to the substantial time interval represented by some nannoplankton zones (e.g., NN 11). The absence of datum points in Hole $388 \mathrm{~A}$ allows us only to interpret average rates of accumulation.

\section{CORRELATION OF SEISMIC REFLECTION PROFILES WITH DRILLING RESULTS}

The seismic reflection profile made while approaching Site 388 (Figure 7) showed, as expected, the same acoustic stratigraphy as the Vema 23 reference profile (Figure 3). The most prominent reflector, the nearly horizontal horizon $A$, is widespread in the western Atlantic (Ewing and Hollister, 1972). Other reflectors known from the Vema data are poorly defined on the Challenger profile. They are obscured, in part, by the coda of the bubble pulse from the more prominent reflectors and are not well defined because of the low-energy airguns used (one $40 \mathrm{cu}$. in. and one 10 cu. in. gun towed in array). We increased the airgun size to two $40 \mathrm{cu}$. in. for the profile made leaving the site and a much better profile resulted (Figure 17). On this profile we identified the same prominent reflectors, $A, A^{*}, \beta$, and basement (Figure 18), as seen on the Vema 23 profile. We detected other reflectors shallower than horizon $A$ in what appears to be a structureless transparent layer on the Vema data. A weakly reflective, nearly flat-lying horizon is present at a sub-bottom depth of about $0.30 \mathrm{sec}$. This horizon passes beneath the topographic relief of the lower continental rise hills, which apparently are formed by the bedding structures in the shallowest layer. The reflector at $0.30 \mathrm{sec}$. could correspond to reflector $X$ of Markl et al. (1970), which is found farther south under the continental rise (Figure 18).

Correlation with the drilling results indicates that the increased stiffness of the Miocene hemipelagic clays at a sub-bottom depth of 284 to 330 meters probably causes reflection horizon $X(?)$ (Figure 18). The induration and dewatering of the clays at that depth give a slightly denser sediment.

If the correlation of the stiff clays with this reflector is correct, then the calculated seismic velocity for the

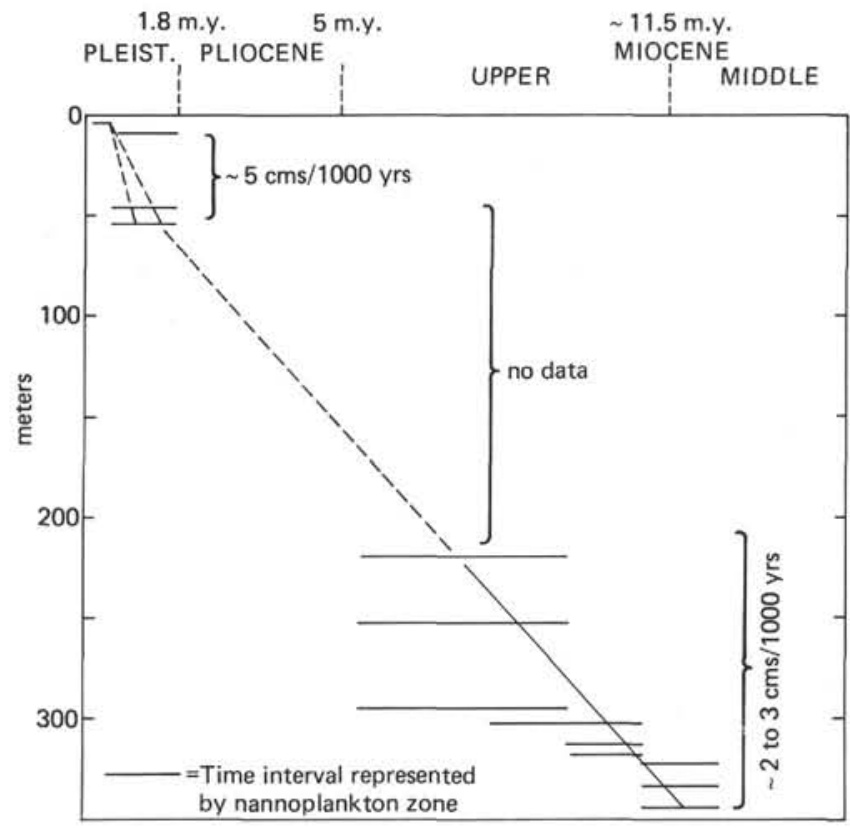

Figure 16. Average rate of sediment accumulation at Site 388. 
E

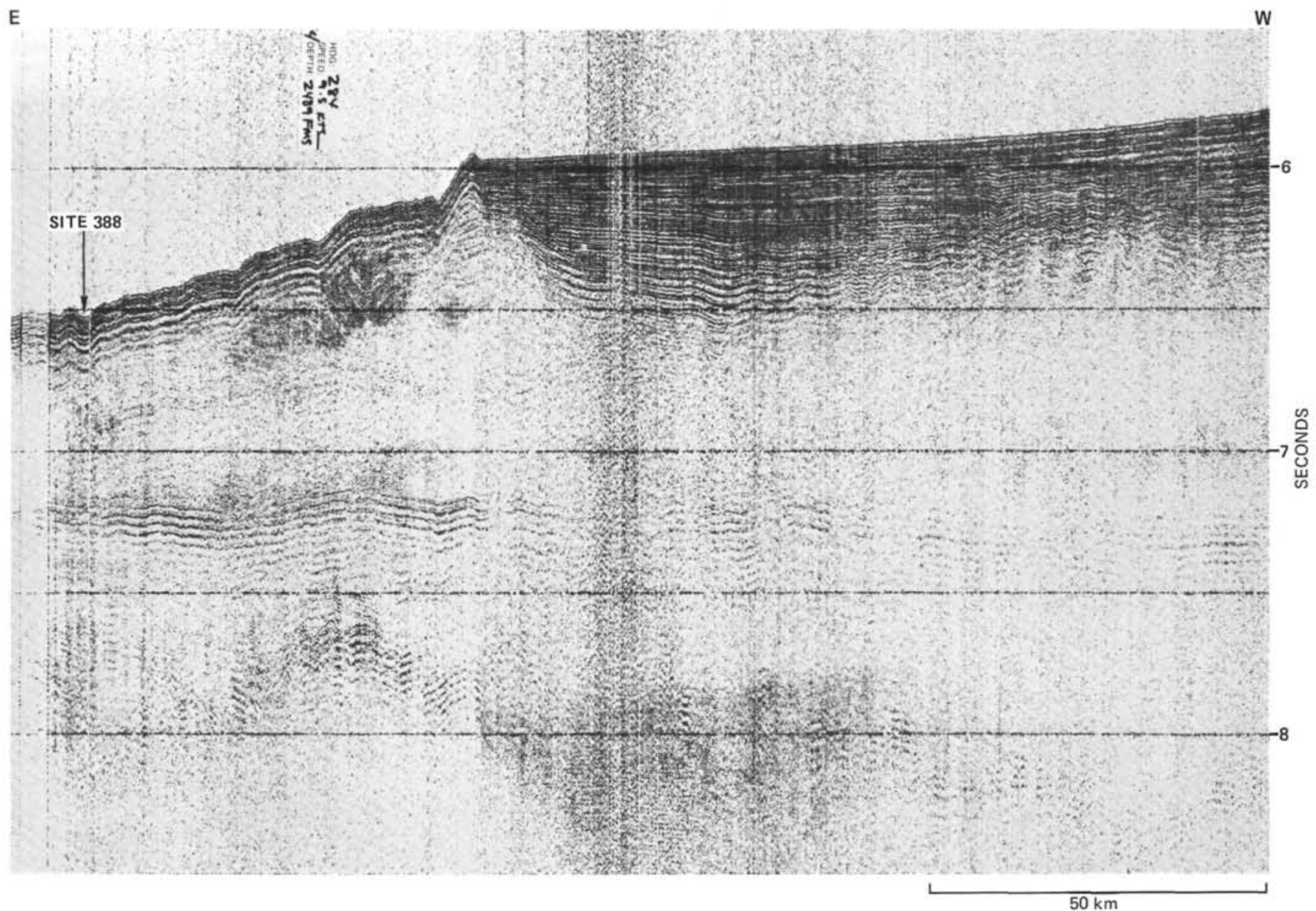

Figure 17. Seismic reflection profile recorded after Glomar Challenger left Site 388. Local times are used.

sediments above the 0.30 -sec deep reflector $X(?)$ is 1.89 $\mathrm{km} / \mathrm{sec}$. This is an unusually high value, and is higher than the velocity of measured laboratory samples. Perhaps the in situ physical properties of the sediments are different from those measured in the laboratory. Stoll et al. (1971) have experimented with velocity measurements of clathrate-bearing sediments and they show that such sediments might have abnormally high seismic velocities, up to about $2.0 \mathrm{~km} / \mathrm{sec}$. The presence of clathrate-bearing sediment at Site 388 might explain this difference between in situ and measured values.

No reflector could be correlated with the boundary between the Pleistocene-Holocene turbidite sands and the underlying hemipelagic clays. This boundary would be in the coda of the sea-floor bubble pulse and not distinguishable on the airgun profiles (Figure 18).

\section{SUMMARY AND CONCLUSIONS}

We drilled Site 388 with four major objectives in mind: (1) to determine the age and character of basement, (2) to determine the origin of the lower continental rise hills, (3) to correlate the major seismic reflectors with the lithology, and (4) to study specific units expected to be in the area especially the carbonaceous mud and metalliferous limestone. Unfortunately, because of technical difficulties we abandoned Hole $388 \mathrm{~A}$ after drilling to a depth of only
341 meters. Thus, the data recovered are pertinent only to one of our objectives: the origin of the lower continental rise hills.

We were able to identify a heretofore unknown reflector above horizon $A$, which might correlate with the reflector recognized elsewhere in the western North Atlantic (Figure $18)$. Drilling at Site 388 proved that this reflector $(X$ ?) corresponds to a very stiff upper Miocene clay. The same seismic profiles show details of shallow bedding structures in the lower continental rise hills and thereby provide important constraints on the possible theories for the origin of the hills.

We also recovered methane-bearing sediments and obtained possible evidence of the presence of clathrates. Because the sediments recovered are similar to those of the Blake-Bahama Outer Ridge, including occurrences of siderite and other carbonate minerals at both sites, the presence of clathrates would not be surprising. Indeed workers have demonstrated that they would expect them to be present in the depth range of the sediments drilled.

Drilling at the site provided nearly continuous sampling of the middle and upper Miocene section. Very well preserved nannofossils form the basis for a good stratigraphic sequence. In addition, many other fossils (foraminifers, radiolarians, and chitinous forms), some of which have been reworked from Eocene and Cretaceous 


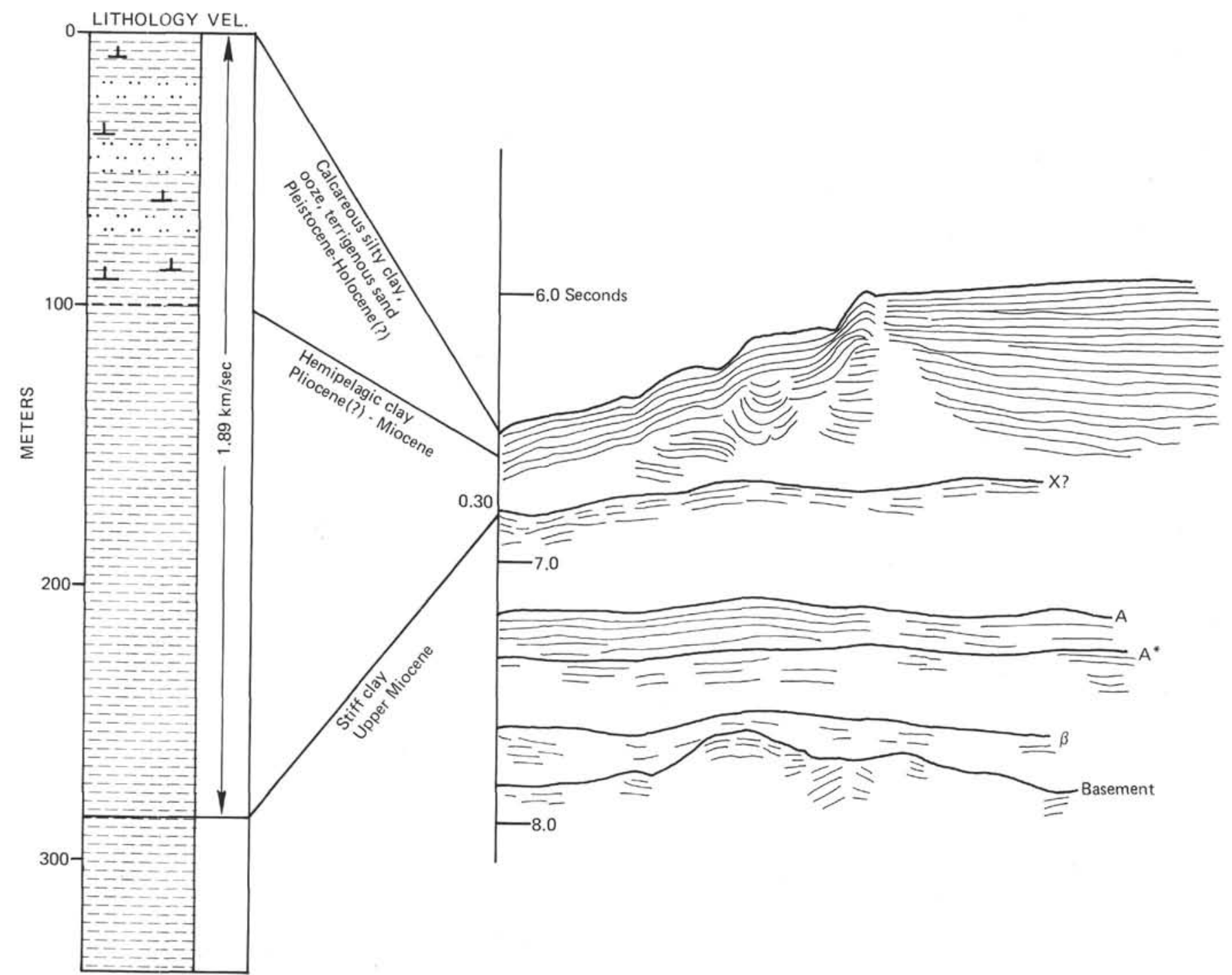

Figure 18. Correlation of seismic profile with lithology, Site 388. Velocities are calculated on the basis of correlation and drilling depth.

sediments are surprisingly well preserved. The drilling results at Site 388 are summarized in Figure 19.

Sedimentologic studies of the cored intervals did not add much new information about the well-studied Quaternary and Miocene-Pliocene sediments sampled previously at nearby Sites 105 and 106. As at Sites 105 and 106 we found evidence that Pleistocene turbidites carried large amounts of terrigenous sand to the site. Limey concretions of bioturbations and well-developed burrows are also present. From these data we can gain some insight into the origin of the lower continental rise hills.

\section{Origin of Lower Continental Rise Hills}

Three possible origins have been postulated for the long low ridges of the lower continental rise. The possible origins have been largely interpreted from reflection profiles such as the Vema 23 profile (Figure 3). They are: (1) erosion of the swales by strong contour-following bottom currents which cut channels into the uppermost horizontally stratified pelagic mud and clay, (2) constructional development of dune-like mud ridges by contour currents, and (3) slump deformation and sliding of the upper Tertiary sediments above horizon $A$ into anticlinal and synclinal folds at the toe of the rise.

On the basis of Glomar Challenger seismic data (Figure 18) and the drilling of Hole 388A (Figure 19), we can analyze these alternatives more rigorously.

1) Erosion hypothesis. Figure 18 clearly shows bedding structures that are not truncated by the swales. Thus, we can eliminate erosion as the origin for the lower continental rise hills.

2) Constructional hypothesis. A constructional origin appears to be consistent with the data obtained at Site 388 . The seismic reflection profiles show that only the shallowest bed forms above the upper Miocene reflector $X(?)$ are involved in the relief of the hills. We know a strong thermohaline circulation existed farther south during the same time which resulted in the construction of the Blake-Bahama Outer Ridge. The sediments from Hole $388 \mathrm{~A}$ show bedding structures indicative of current deposition. Although disturbed by drilling, the beds are relatively horizontal and in some places are graded. This is 


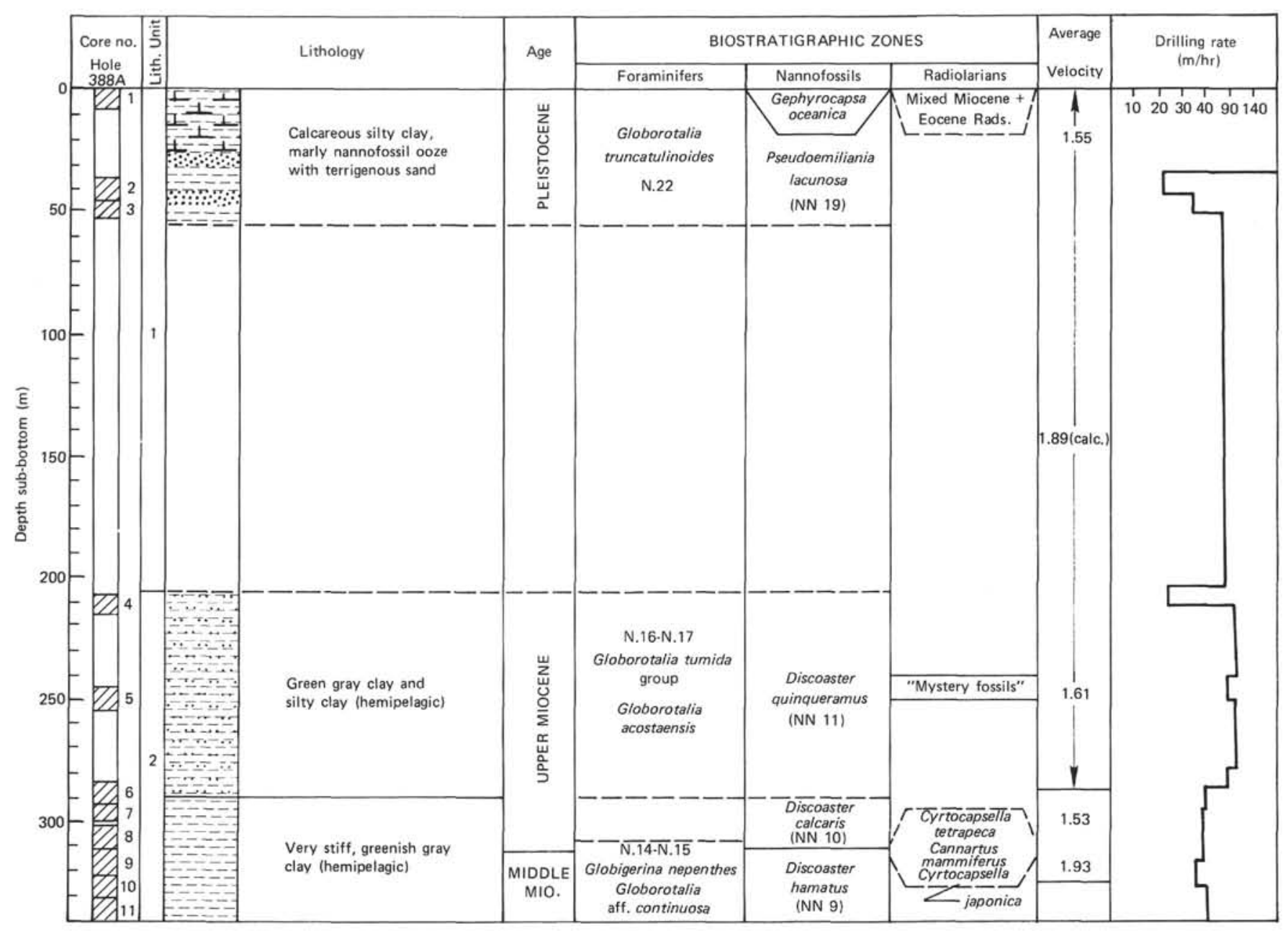

Figure 19. Graphic summary of Hole $388 \mathrm{~A}$.

the case especially in the stiffer clays where the bedding is less disturbed by coring. Limy crusts and burrows could have been produced during minor pauses in sedimentation caused by mild bottom currents which allowed bottom-dwelling organisms to become established.

Finally, the details of the bedding structures under the hills are most diagnostic (Figure 18). Although obscured by the coda of the ocean floor reflection, the hills clearly are underlain by synclinal rather than anticlinal beds. The synclinal beds could be caused by the westward migration of dune-like foreset bed forms as shown in Figure 20a which would result in the axial plane being tilted upslope. Such migration would be consistent with cross-ridge pressure gradients toward the west produced by the Coriolis force on southward-flowing contour currents, as proposed by Heezen and Hollister (1972).

3) Slump deformation hypothesis. The data obtained at Site 388 could also be interpreted to favor an origin by slumping, although not by compression of the muds at the toe of a massive sliding unit above horizon $A$ as previously envisioned (Schlee et al., 1976). Any slumping that may have occurred affected beds above reflecting horizon $X(?)$ and happened after deposition of the upper Miocene and Pliocene hemipelagic clays - those involved in the relief of the lower continental rise hills. Thus, if there has been slumping by gravity gliding, reflector $X($ ?) might have been the décollement above which the more watery Miocene and
Pliocene hemipelagic clays sheared. However, a continuous sequence of cores from Hole 388A spans this possible decollement and shows no evidence of shearing or folding. On the contrary, simple, nearly horizontal beds with delicate burrows are clearly visible and transitional changes above and below the stiff clays of reflector $X(?)$ indicate a normal stratigraphic contact (see Lithology). Although this would negate gliding at reflector $X(?)$, shearing over a shallower décollement in the uncored interval (55-208 m sub-bottom) could have taken place.

In the slump hypothesis the apparent synclinal forms below the ridges would have been caused by the rotation of faulted slump blocks as they slipped down on the east, as suggested by Ballard (1966). However, if this hypothesis is correct, the faults must be tensional and the slumped blocks must be in the heel area of the slumped mass rather than in the compressional region at the toe. Local slumping a short distance from the area of the hills might then have occurred but massive sliding of the clays down to basin from as far west as the continental slope is unlikely.

\section{REFERENCES}

Bader, R.G., et al., 1970. Initial Reports of the Deep Sea Drilling Project, Volume 4: Washington (U.S. Government Printing Office).

Ballard, J.A., 1966. Structure of the Lower Continental Rise Hills of the Western North Atlantic: Geophysics, v. 31, p. 506-523. 


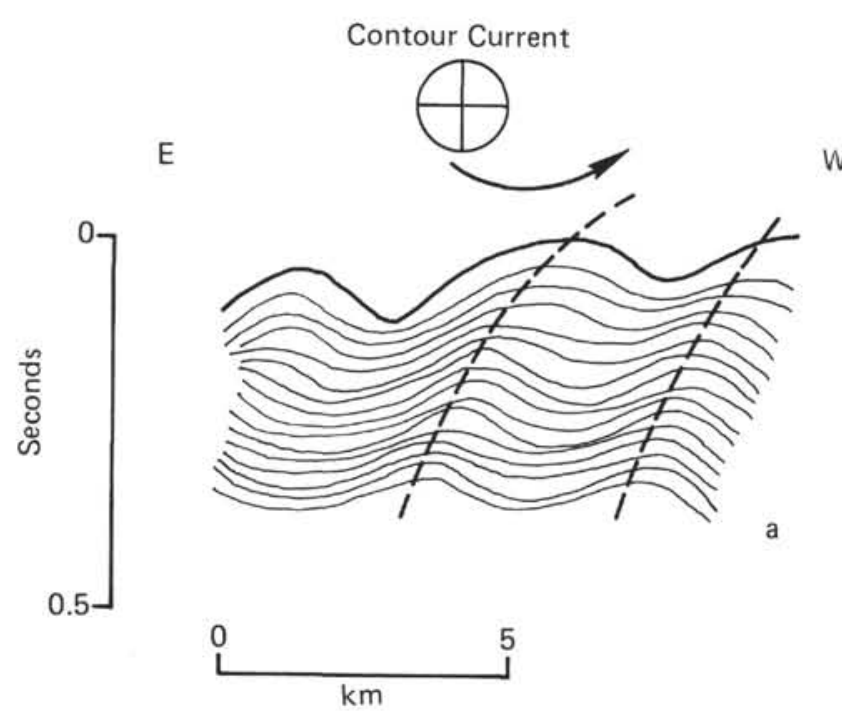

E

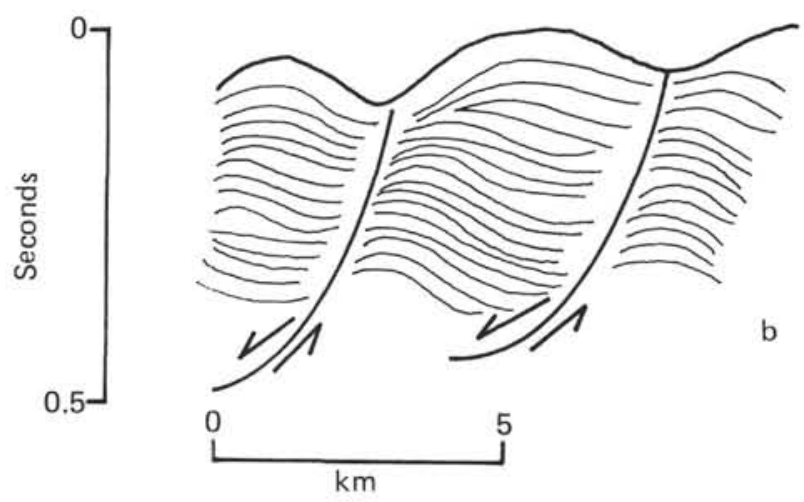

Figure 20. Two possible origins of the lower continental rise hills: (a) after Heezen and Hollister, 1972; (b) after Ballard, 1966.

Barrett, D.L. and Keen, C.E., 1976. Mesozoic magnetic lineations, the Magnetic Quiet Zone, and sea floor spreading in the Northwest Atlantic: J. Geophys. Res., v. 81, p. 4875-4884.

Berggren, W.A., 1972. A Cenozoic time scale - some implications for regional geology and paleobiogeography: Lethaia, v. 5, p. 195-215.

1973. The Pliocene time scale: calibration of planktonic foraminiferal and calcareous nannoplankton zones: Nature, v. 243, p. 391-397.

Berggren, W.A., McKenzie, D.P., Sclater, J.G., and van Hinte, J.E., 1975. World-wide correlation of mesozoic magnetic anomalies and its implications: Discussions and reply: Geol. Soc. Am. Bull., v. 86, p. 267-272.

Blow, W.H., 1967. Late middle Eocene to Recent planktonic foraminiferal biostratigraphy: Proc. Int. Plankt. Conf., Geneva, v. 1, p. 199-422.

Bukry, D., 1973. Coccolith stratigraphy, Eastern Equatorial Pacific, Leg 16 Deep Sea Drilling Project. In van Andel, T.H.,
Project, Volume 16: Washington (U.S. Government Printing Office), p. 653-700.

Boyce, R. E., 1973. Physical properties-methods. In Edgar, N.T., Saunders, J.B., et al., Initial Reports of the Deep Sea Drilling Project, Volume 15: Washington (U.S. Government Printing Office), p. 1115-1124.

Degens, E.T. and Ross, D.A. (Eds.), 1969. Hot brines and recent heavy metal deposits in the Red Sea: New York, (Springer Verlag).

Drake, C.L., Heirtzler, J.R., and Hirshman, J., 1963. Magnetic anomalies off eastern North America: J. Geophys. Res., v. 68, p. 5259-5275.

Emery, K.O., Uchupi, E. Phillips, J.D., Bowin, C.O., Bunce, E., and Knott, S., 1970. Continental Rise of Eastern North America: Am. Assoc. Petrol. Geol. Bull., v. 54, p. 44-108.

Ewing, J.I. and Hollister, C.D., 1972. Regional aspects of deep sea drilling in the western North Atlantic. In Hollister, C.D., Ewing, J.I., et al., Initial Reports of the Deep Sea Drilling Project, Volume 11: Washington (U.S. Government Printing Office), p. 951-973.

Ewing, M., Worzel, J.L., et al., 1969. Initial Reports of the Deep Sea Drilling Project, Volume 1: Washington (U.S. Government Printing Office).

Gieskes, Joris M., 1974. Interstitial water studies, Leg 25. In Vallier, T. L., White, S. M., et al., Initial Reports of the Deep Sea Drilling Project, Volume 25: Washington (U.S. Government Printing Office), p. 361-394.

Gieskes, Joris M., and Lawrence, James R., 1976. Interstitial water studies, Leg 35. In Hollister, C. D., Craddock, C., et al., Initial Reports of the Deep Sea Drilling Project, Volume 35: Washington (U.S. Government Printing Office), p. 407-424.

Heezen, B.C. and Hollister, C.D., 1972. The face of the deep: New York (Oxford Univ. Press).

Hollister, C.D., Ewing, J.I., et al., 1972. Initial Reports of the Deep Sea Drilling Project, Volume 11: Washington (U.S. Government Printing Office).

Kaplan, I.R., 1974. Natural gases in marine sediments: Marine Science, v. 3, New York (Plenum Press).

Lamb, J.L. and Beard, J.H., 1972. Late Neogene planktonic foraminifers in the Caribbean, Gulf of Mexico, and Italian Stratotypes: Univ. Kansas Paleontol. Contrib., Art. 57, no. 8, p. 1-67.

Lancelot, Y., Seibold, E., et al., 1975. The eastern North Atlantic: Geotimes, v. 20, p. 18-21.

Larson, R.L. and Hilde, T., 1975. A revised time scale of magnetic reversals for the Early Cretaceous, Late Jurassic: $J$. Geophys. Res., v. 80, p. 2586-2594.

Markl, R.G., Bryan, G.M., and Ewing, J.I., 1970. Structure of the Blake-Bahama Outer Ridge: J. Geophys. Res., v. 75, p. 4539-4555.

Maxwell, A.E., et al., 1970. Initial Reports of the Deep Sea Drilling Project, Volume 3: Washington (U.S. Government Printing Office).

McElhinney, M.W. and Burek, P.J., 1971. Mesozoic paleomagnetic stratigraphy: Nature, v. 232, p. 98-102.

Needham, H.D., Habib, D., and Heezen, B.C., 1969. Upper carboniferous palynomorphs as a tracer of red sediment dispersal patterns in the northwest Atlantic: J. Geol., v. 77, p. 113-120.

Perch-Nielsen, K., 1975. Eocene to Paleocene microfossil of unknown affinity. In Kennett, J.P., Houtz, R.E., et al., Initial Reports of the Deep Sea Drilling Project: Washington (U.S. Government Printing Office), p. 909-912.

Phleger, F.B., Parker, F.L., and Peirson, J.F., 1953. North Atlantic foraminifera: Rept. Swedish Deep-Sea Exped., v. 7, p. $1-121$. 
Poag, C.W., 1972. Neogene planktonic foraminiferal biostratigraphy of the western North Atlantic, DSDP Leg 11. In Hollister, C.D., Ewing, J.I., et al., Initial Reports of the Deep Sea Drilling Project, Volume 11: Washington (U.S. Government Printing Office), p. 483-522.

Rabinowitz, P.D., 1974. The boundary between oceanic and continental crust in the western North Atlantic: In Burk, C.A. and Drake, C.L. (Eds.); The geology of continental margins: New York (Springer Verlag), p. 67-84.

Ryan, W.B.F., et al., in press. The title of this article is not available on board Glomar Challenger : Riv. Ital. Pal. Strat., Milano.

Schlee, J., Mattick, R., Grow, J., and Behrendt, J., 1975. Stratigraphic and structural framework of the Atlantic Continental Margin off the Mid-Atlantic States: Open File Report, U.S. Geological Survey.

Schlee, J., Behrendt, J.C., Grow, J.A., Robb, J.M., Mattick,
R.E., Taylor, P.T., and Lawson, B.J., 1976. Regional framework off northeastern United States: Am. Assoc. Petrol. Geol. Bull., v. 60 , p. $926-951$.

Stoll, R.O., Ewing, J., and Bryan, G.M., 1971. Anomalous wave velocities in sediments containing gas hydrates: J. Geophys, Res., v. 76, p. 2090.

Taylor, P.T., Zietz, I., and Dennis, L.S., 1968. Geologic implications of aeromagnetic data for the eastern Continental Margin of the United States: Geophysics, v. 33, p. 755-780.

Taylor, P.T., Greenwalt, D., Watkins, N.D., and Ellwood, B.B., 1973. Magnetic properties analysis of basalt beneath the Quiet Zone (Abs.): EOS Trans. Am. Geophys. Union, v. 54, p. 255. van Hinte, J.E., 1972. The Cretaceous Time Scale and Planktonic Foraminiferal Zones: Proc. Nederl. Akad. Wetensch., ser. B, 75 , no. 1 , p. $1-8$.

1976. A Jurassic time scale: Am. Assoc. Petrol. Geol. Bull., v. 60 , p. 489-497. 



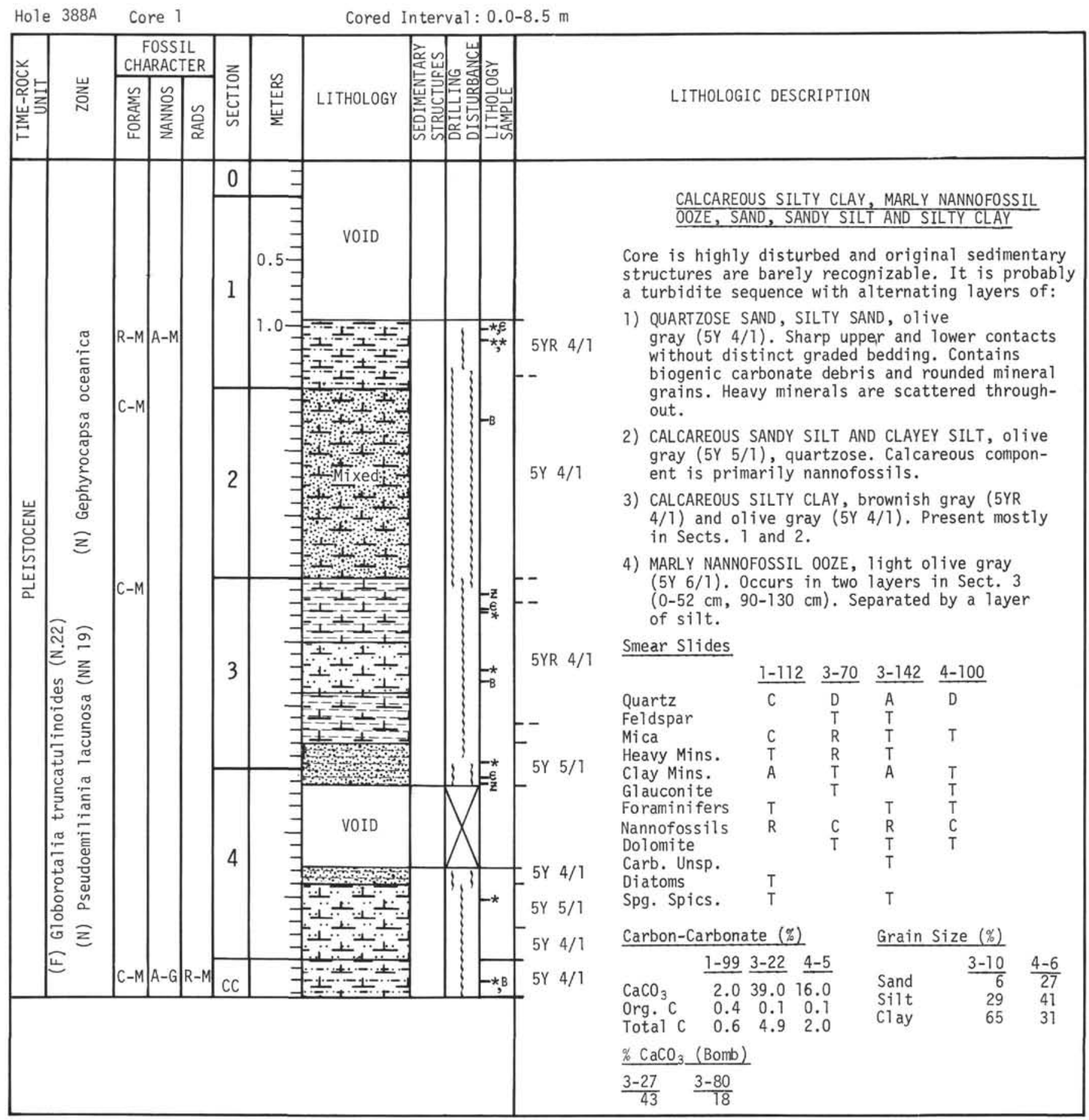




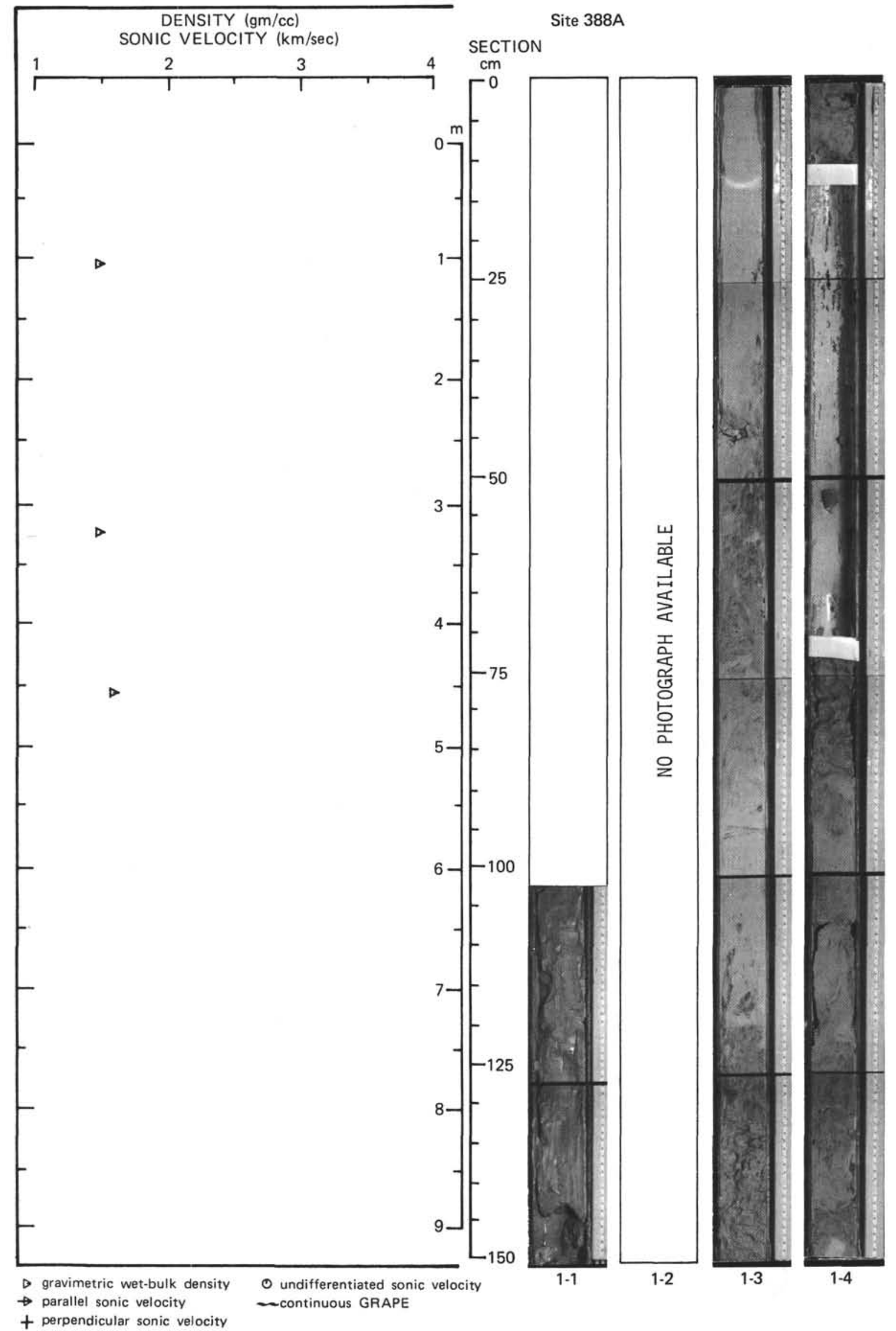




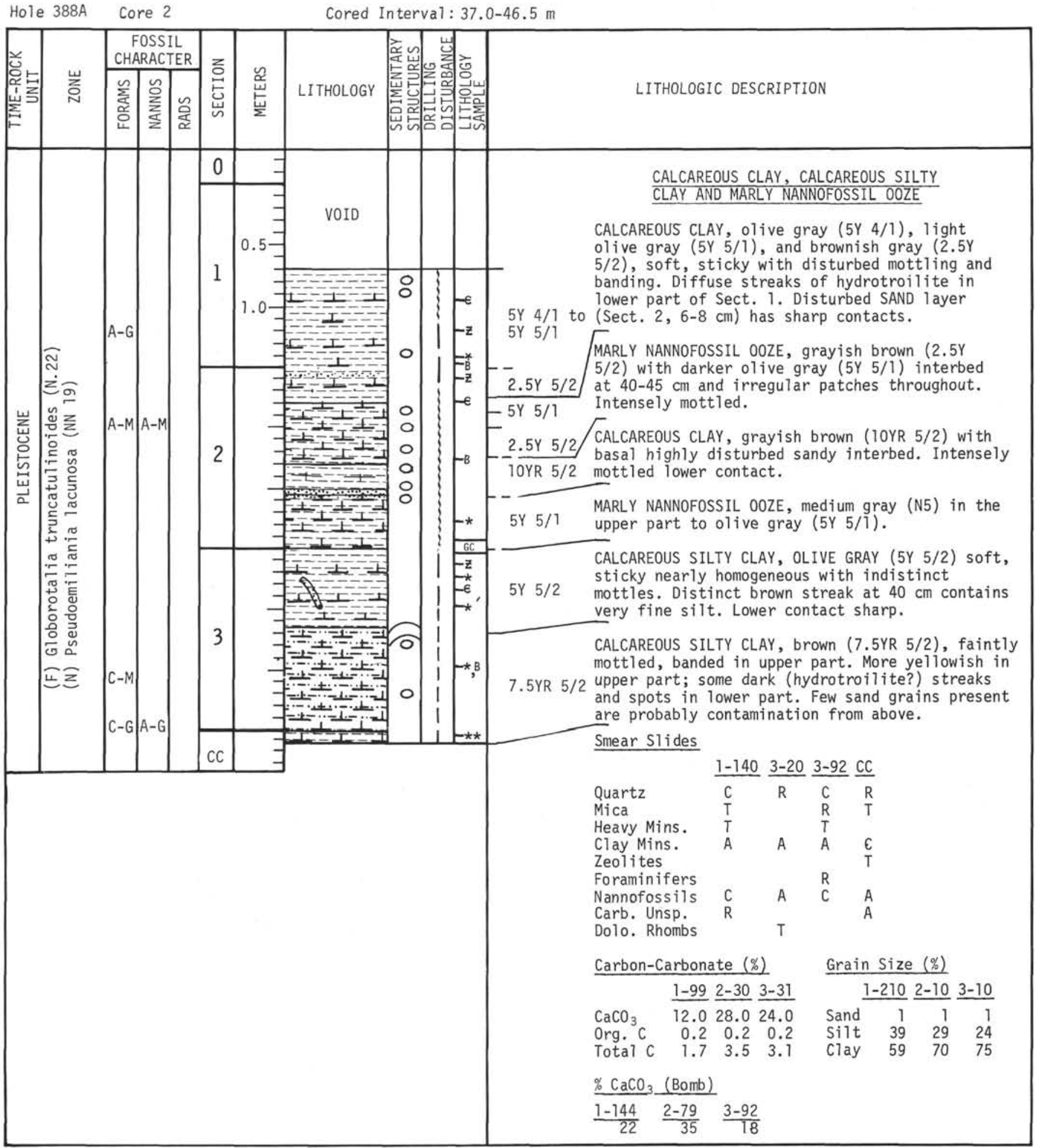


DENSITY $(\mathrm{gm} / \mathrm{cc})$

SONIC VELOCITY $(\mathrm{km} / \mathrm{sec})$

Site 388A

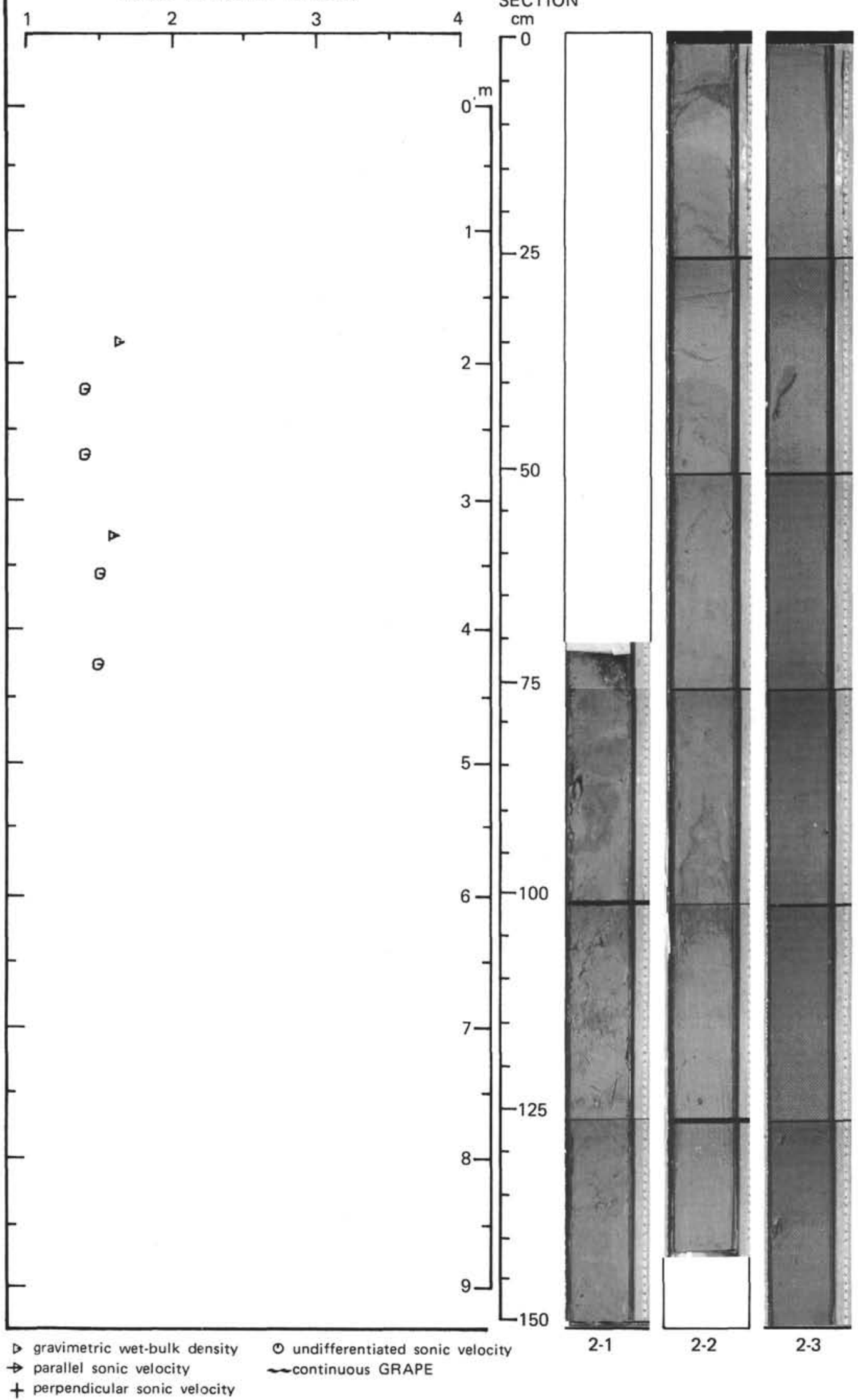

SECTION 


\begin{tabular}{|c|c|c|c|c|c|c|c|c|c|}
\hline \multirow{2}{*}{ 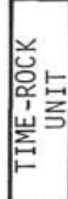 } & \multirow{2}{*}{ 岩 } & \multicolumn{3}{|c|}{$\begin{array}{c}\text { FOSSIL } \\
\text { CHARACTER } \\
\end{array}$} & \multirow{2}{*}{$\begin{array}{l}z \\
\text { 点 } \\
\text { 岕 }\end{array}$} & \multirow[b]{2}{*}{ 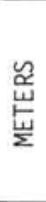 } & \multirow[b]{2}{*}{ LITHOLOGY } & \multirow{2}{*}{ 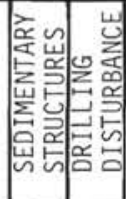 } & \multirow[b]{2}{*}{ LITHOLOGIC DESCRIPTION } \\
\hline & & 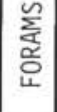 & $\sum_{\substack{n \\
\Sigma}}^{n}$ & $\approx$ & & & & & \\
\hline \multirow{2}{*}{\multicolumn{2}{|c|}{ 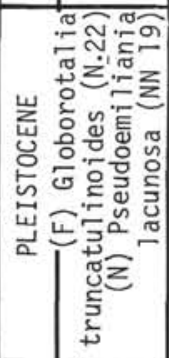 }} & $A-G$ & $A-G$ & & CC & & 고 & $1<1$ & \multirow[b]{2}{*}{$\begin{array}{l}\text { A single small piece of CALCAREOUS CLAY was } \\
\text { found in the core catcher. } \\
\text { *Pressure core barrel. }\end{array}$} \\
\hline & & & & & & & & & \\
\hline
\end{tabular}

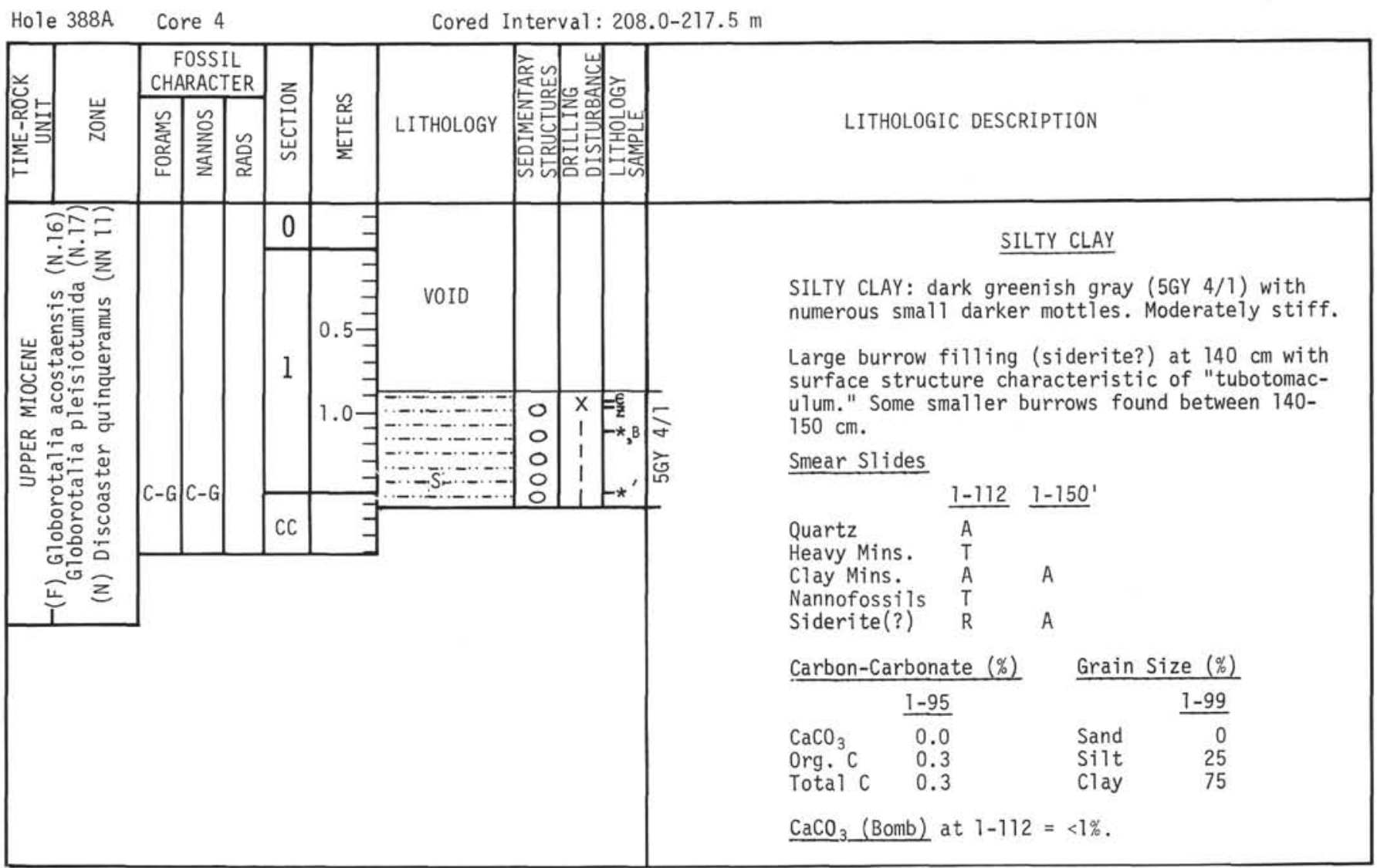




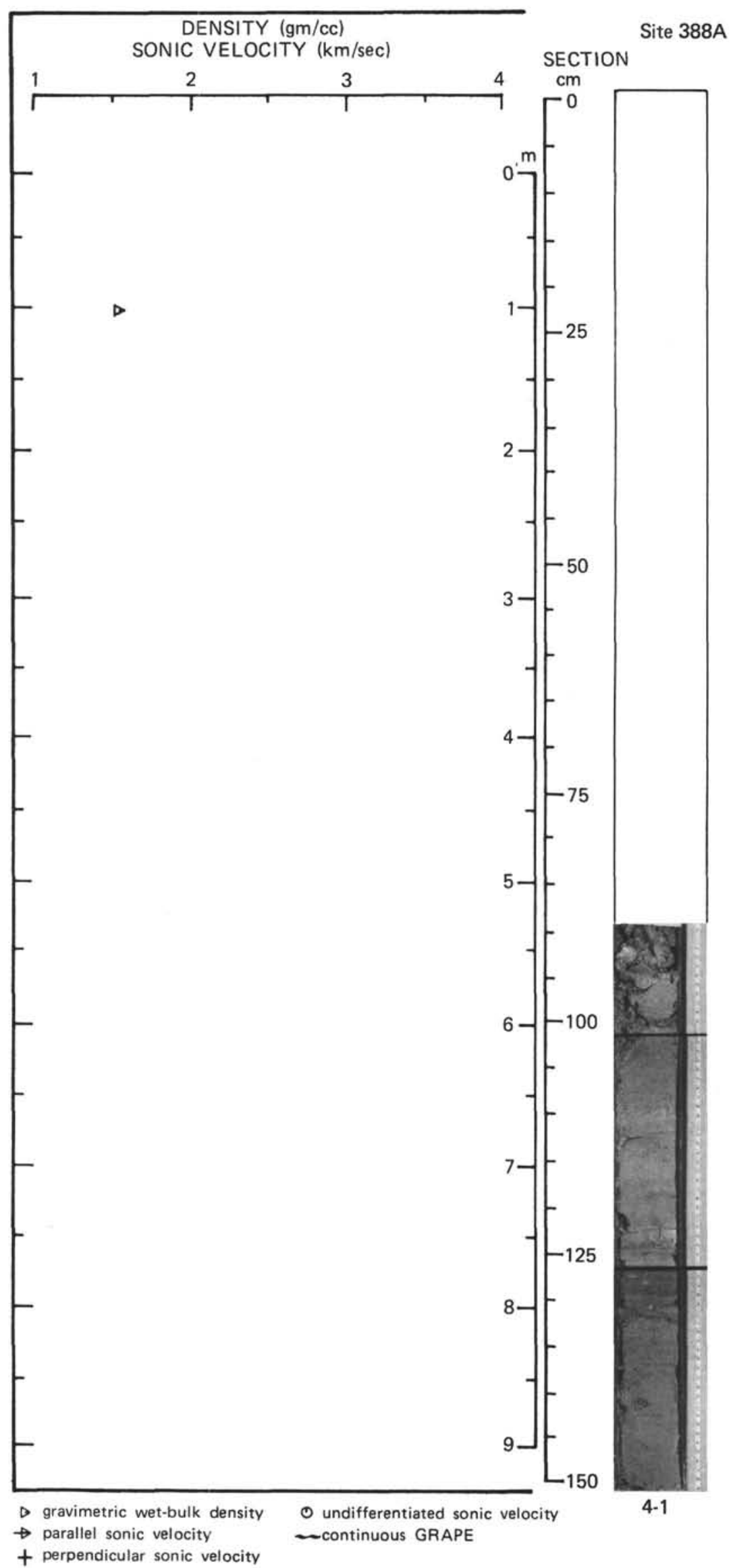


Hole 388 A Core $5 \quad$ Cored Interval: $246.0-255.5 \mathrm{~m}$

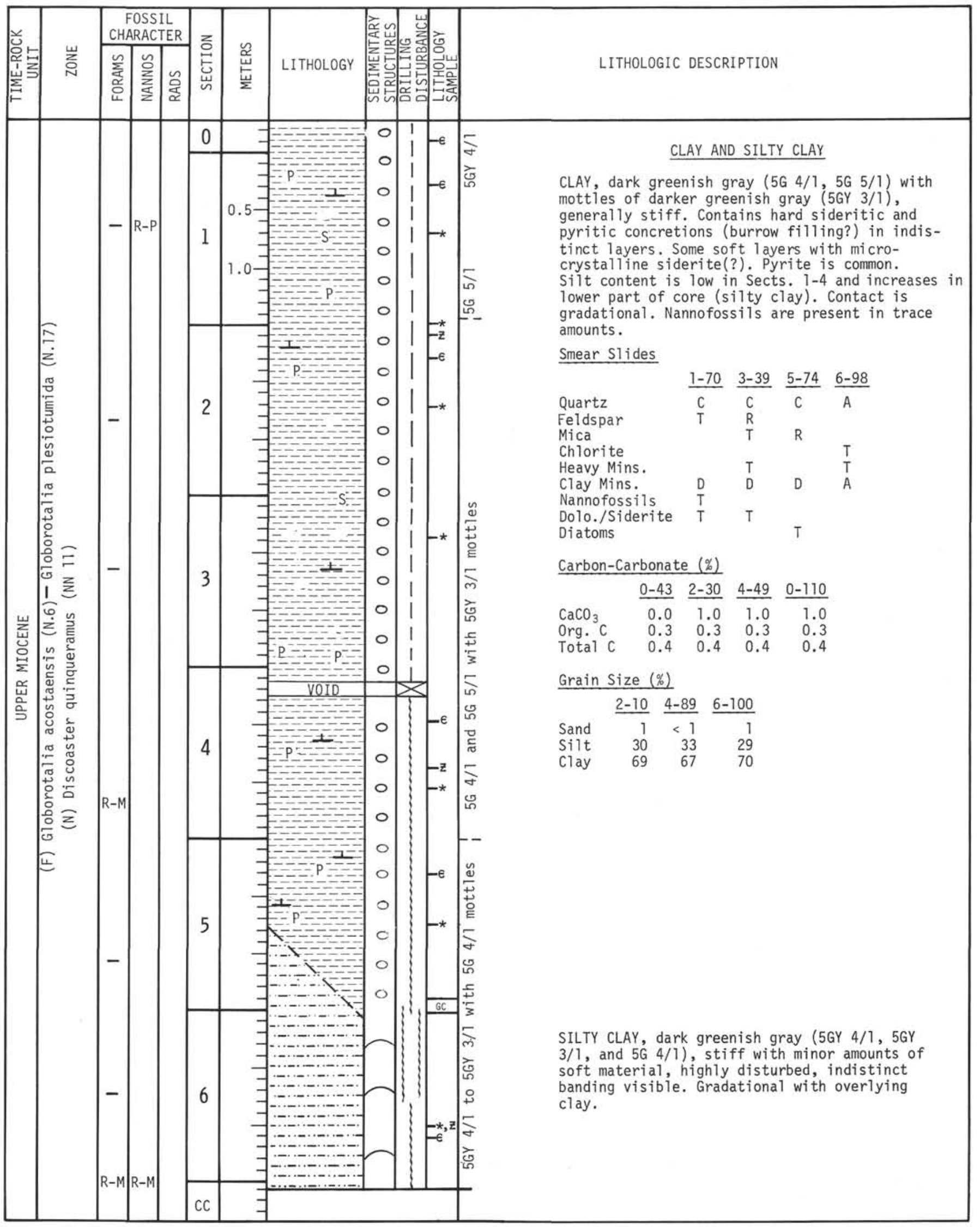




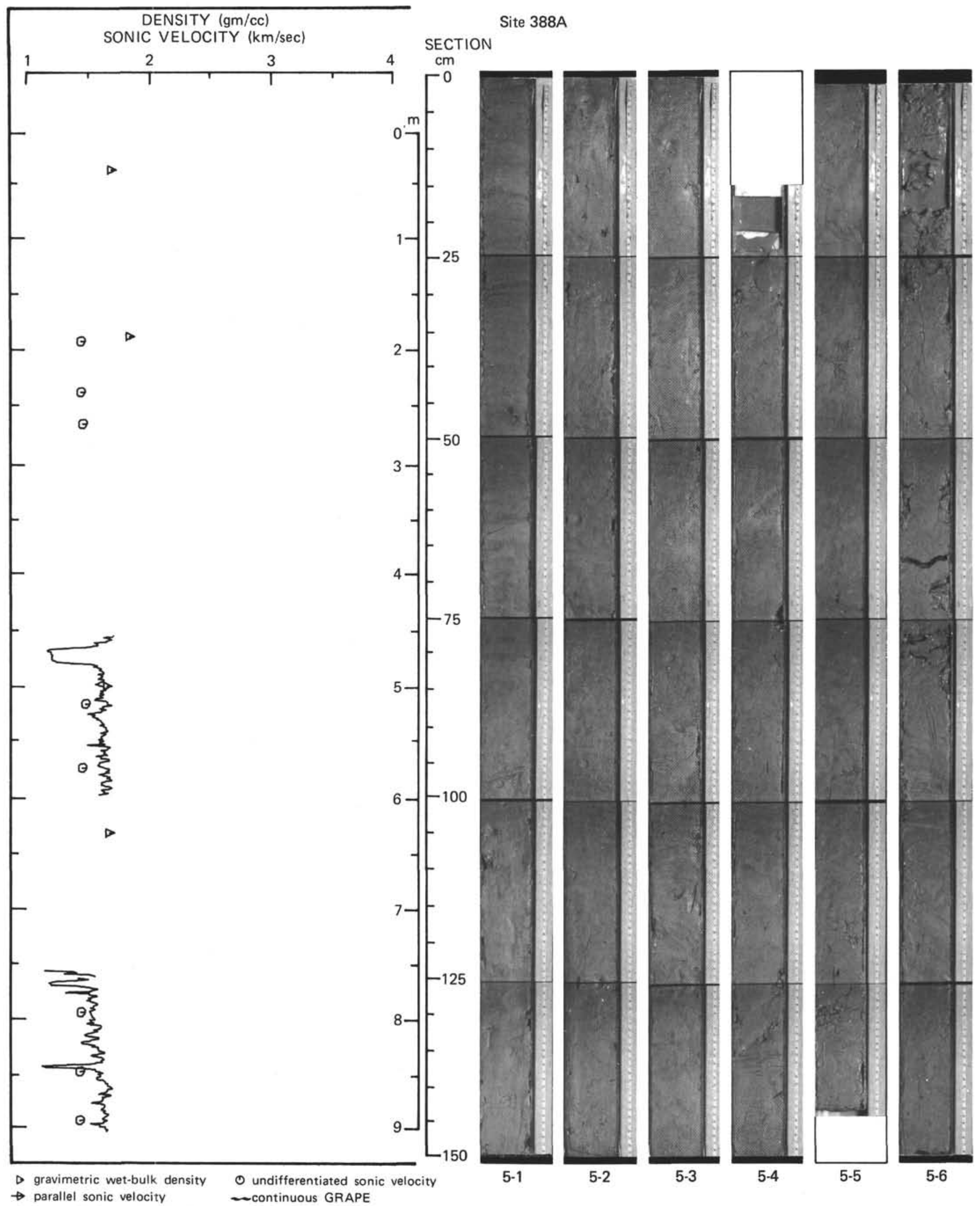


SITE 388

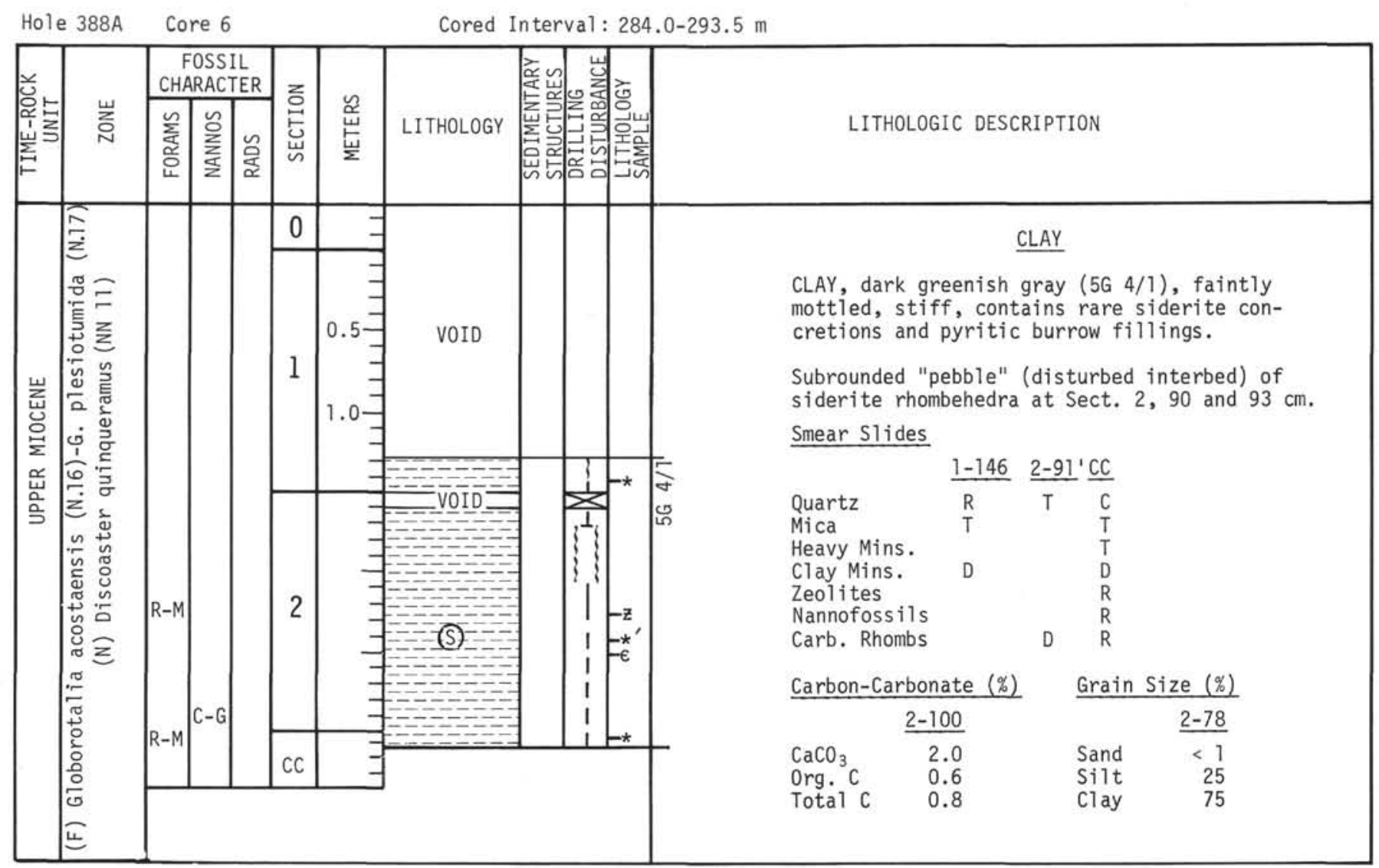




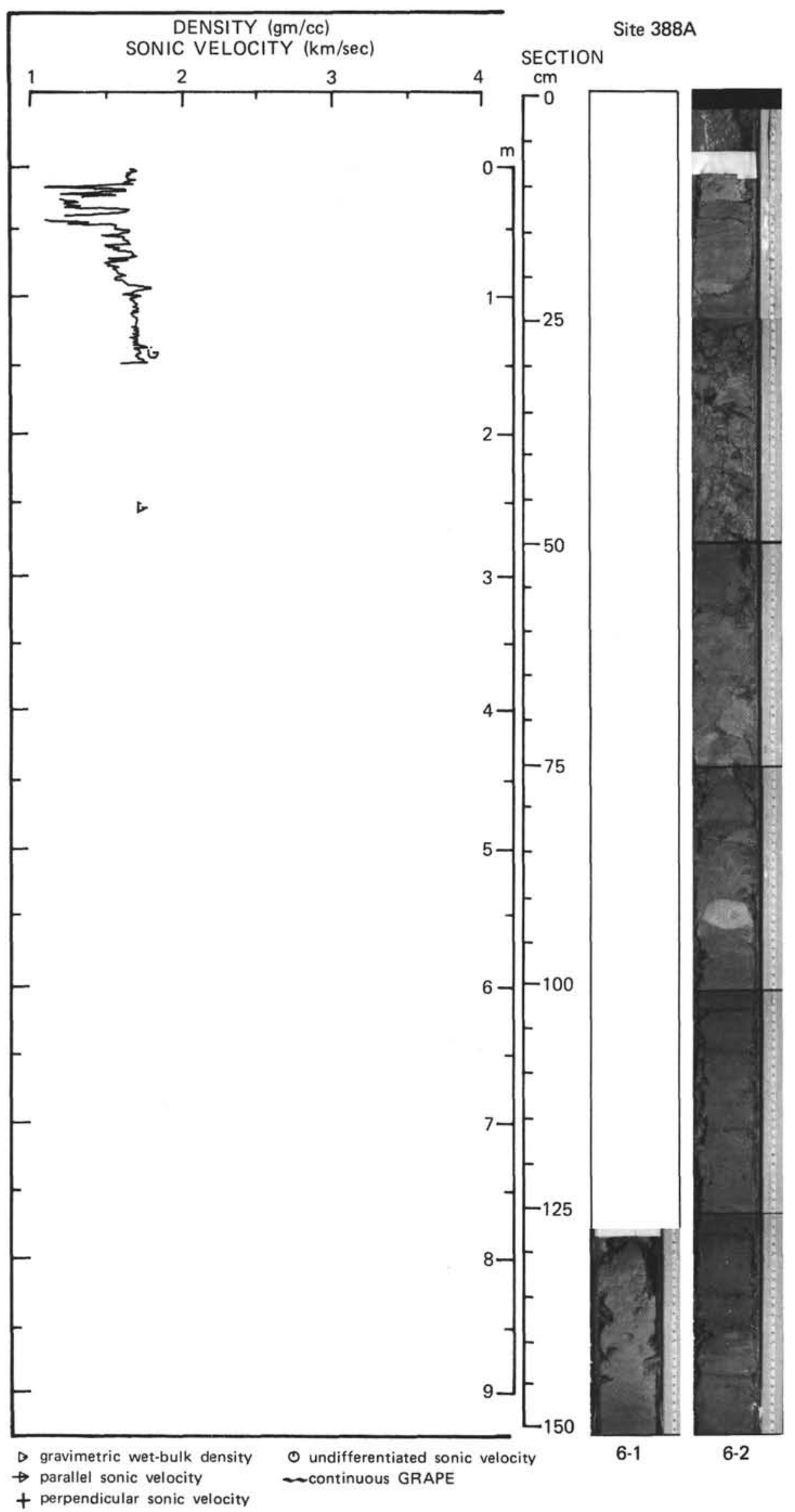




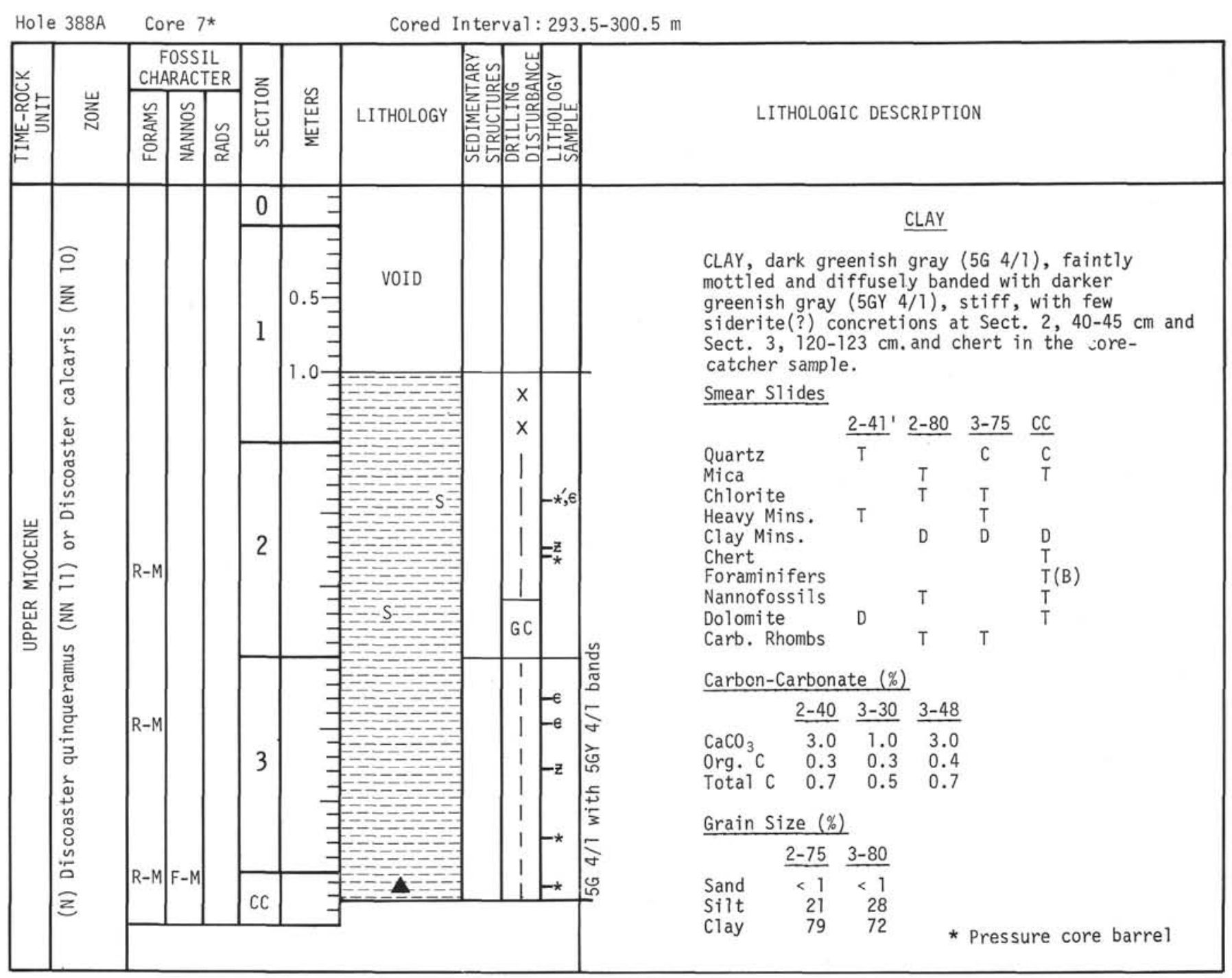




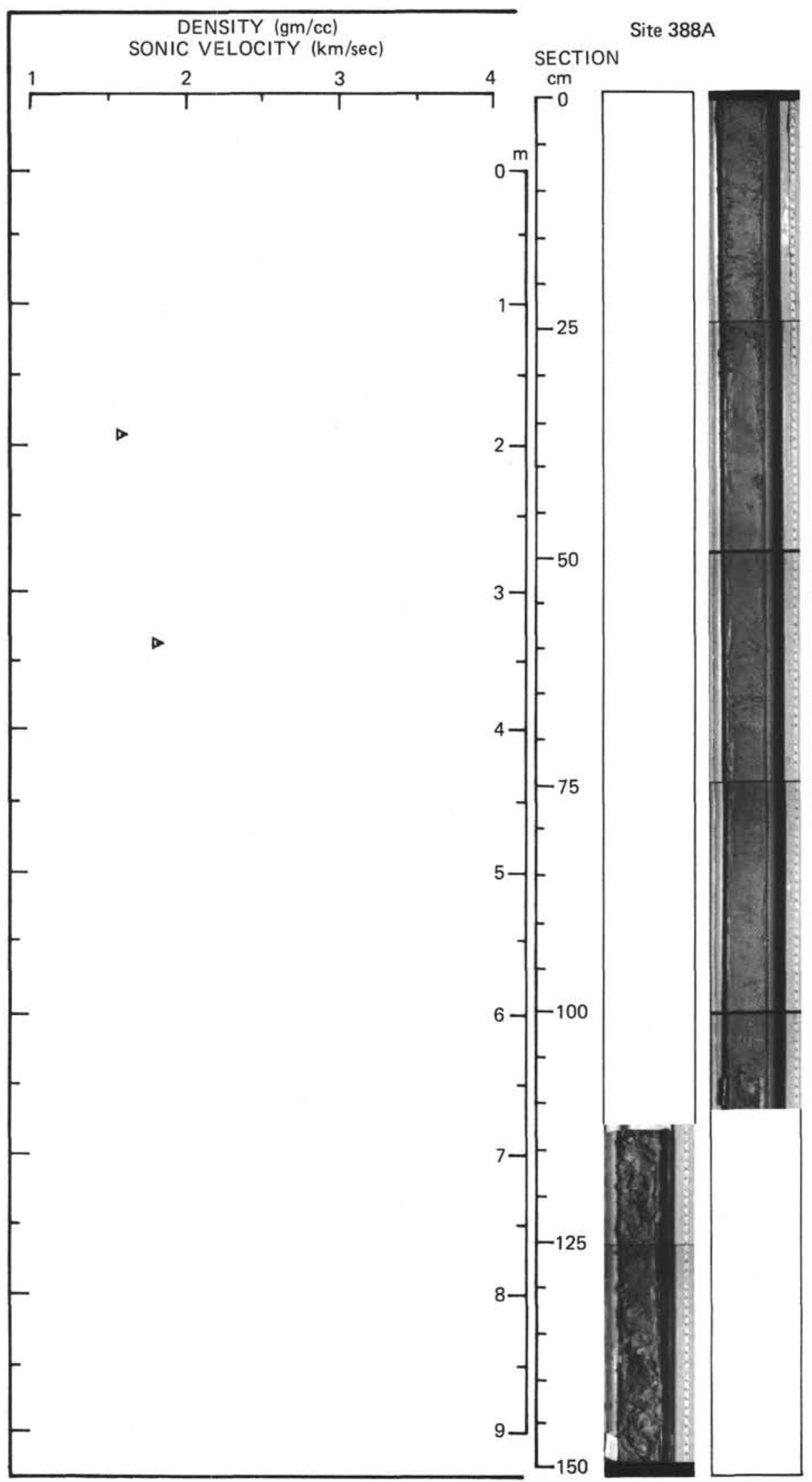

7-1

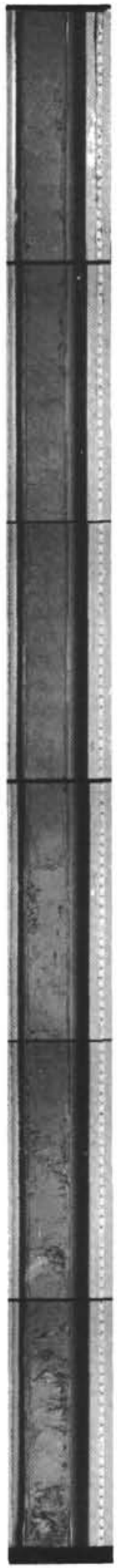

$7-3$ 
Hole 388 A Core 8

Cored Interval: $303.0-312.5 \mathrm{~m}$

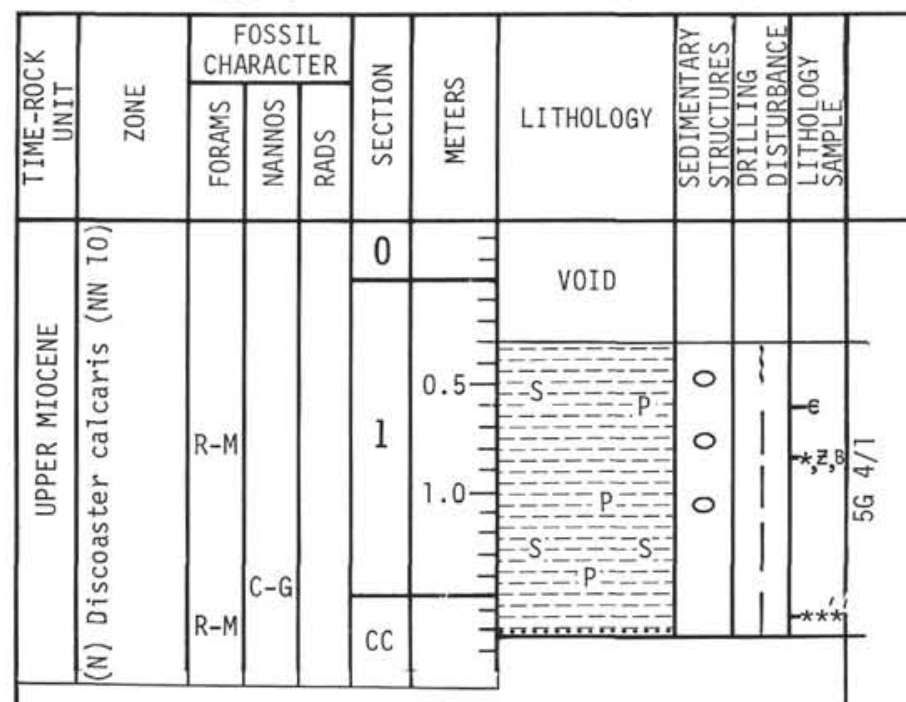

LITHOLOGIC DESCRIPTION

CLAY

CLAY, dark greenish gray ( $5 G 4 / 1$ ), mottled, very stiff, contains pyrite and siderite(?) scattered throughout. Mottles (burrows?) are small and elongated subparallel to bedding.

Mottling is well-developed in upper part of

Sect. 1; below $100 \mathrm{~cm}$ the sediment is more

homogeneous and contains about 5\% nannofossils

and abundant submicroscopic crystals of siderite(?).

Core-catcher sample contains stringers of well-sorted quartzose silt and thin silt

layer at the base.

Smear Slides

$1-85 \mathrm{CC}$ $\mathrm{CC}^{\prime} \quad \mathrm{CC}^{\prime}$

Quartz (DK. Dk. clay) (Streak) (Silt)

Mica C

Heavy Mins.

Clay Mins.

Glauconite

Zeolites

Nannofossils

Carb. Rhombs

Carb. Unsp.

D $T$

Carbon-Carbonate (\%) Grain Size (\%)

$\begin{array}{lllr} & \frac{1-60}{1.0} & & \frac{1-82}{\mathrm{CaCO}_{3} \mathrm{C}} \\ \mathrm{Org.}^{\mathrm{C}} & 0.5 & \text { Sand } & <1 \\ \text { Total C } & 0.6 & \text { Silt } & 16 \\ & & \text { Clay } & 84\end{array}$

$\underline{\mathrm{CaCO}}_{3}$ (Bomb) at $1-85=5 \%$. 


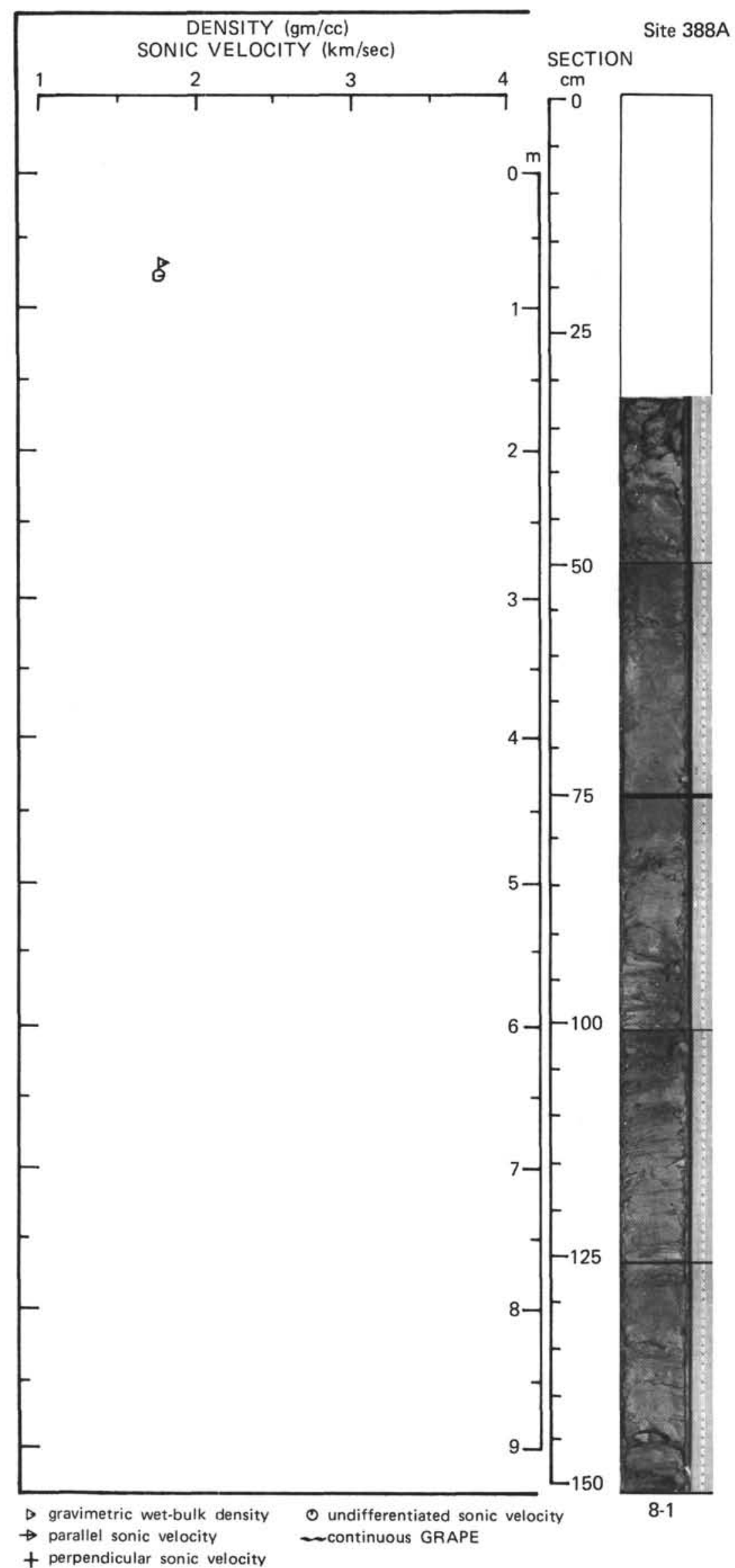


Hole 388A Core 9

Cored Interval: $312.5-322.0 \mathrm{~m}$

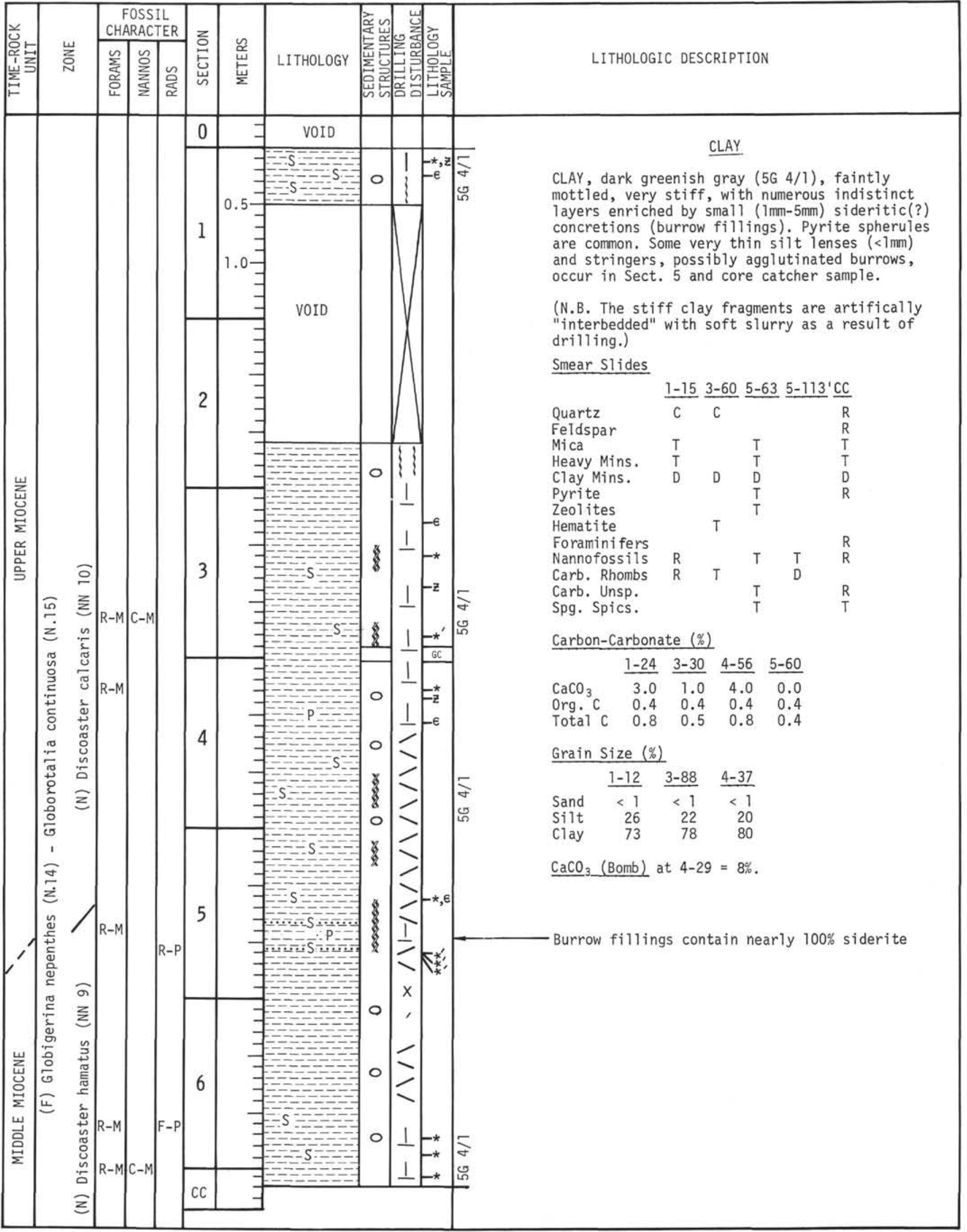




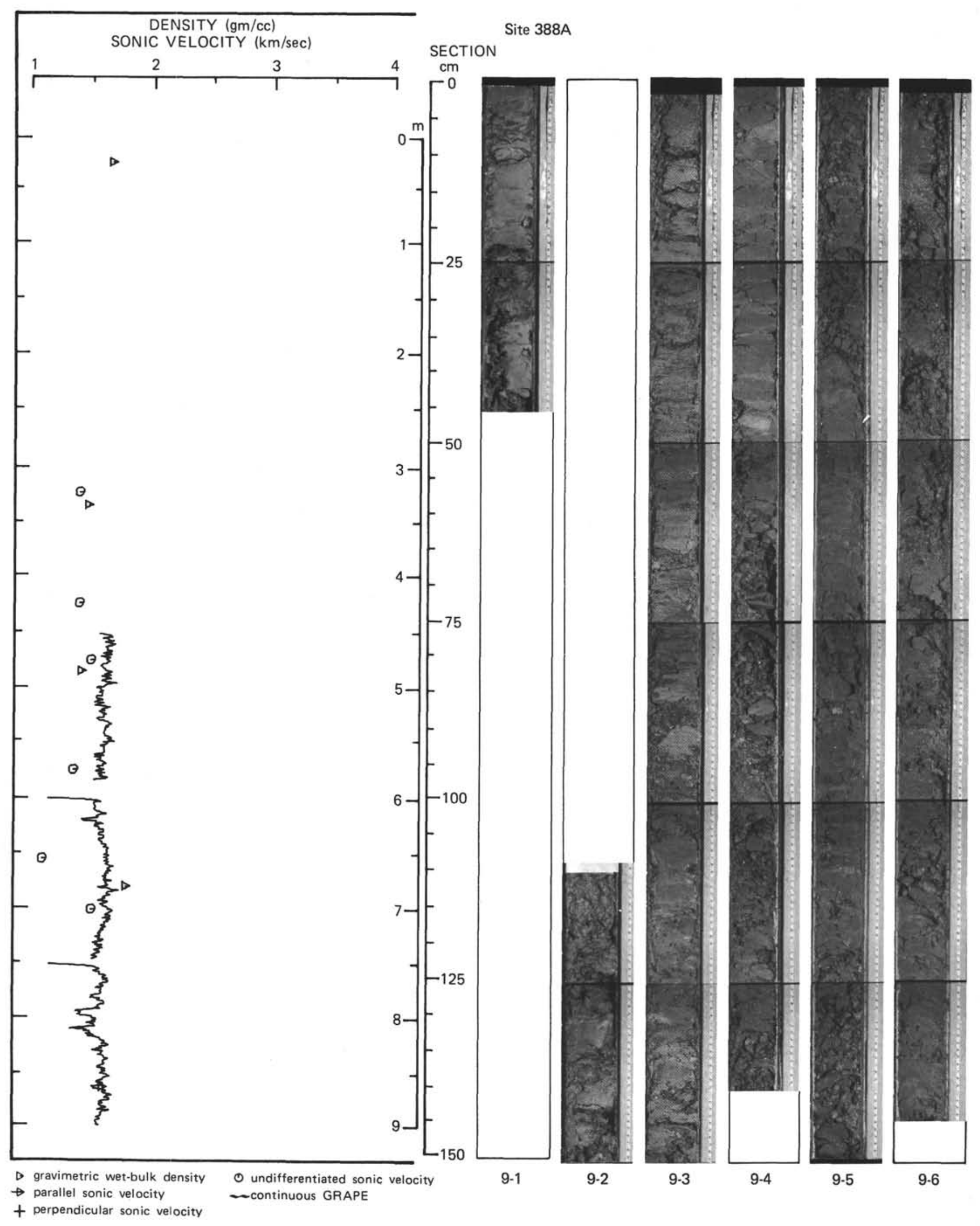




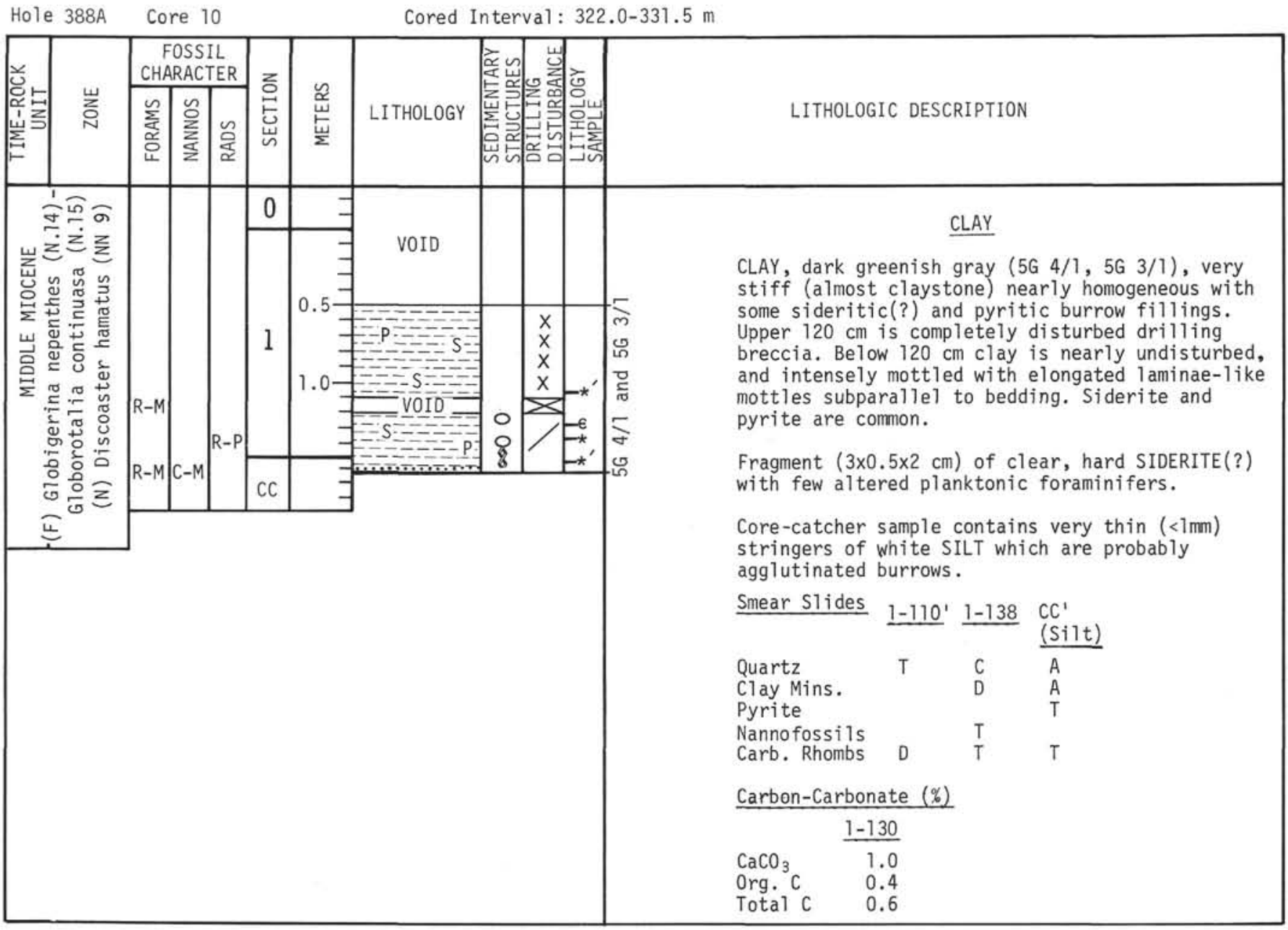




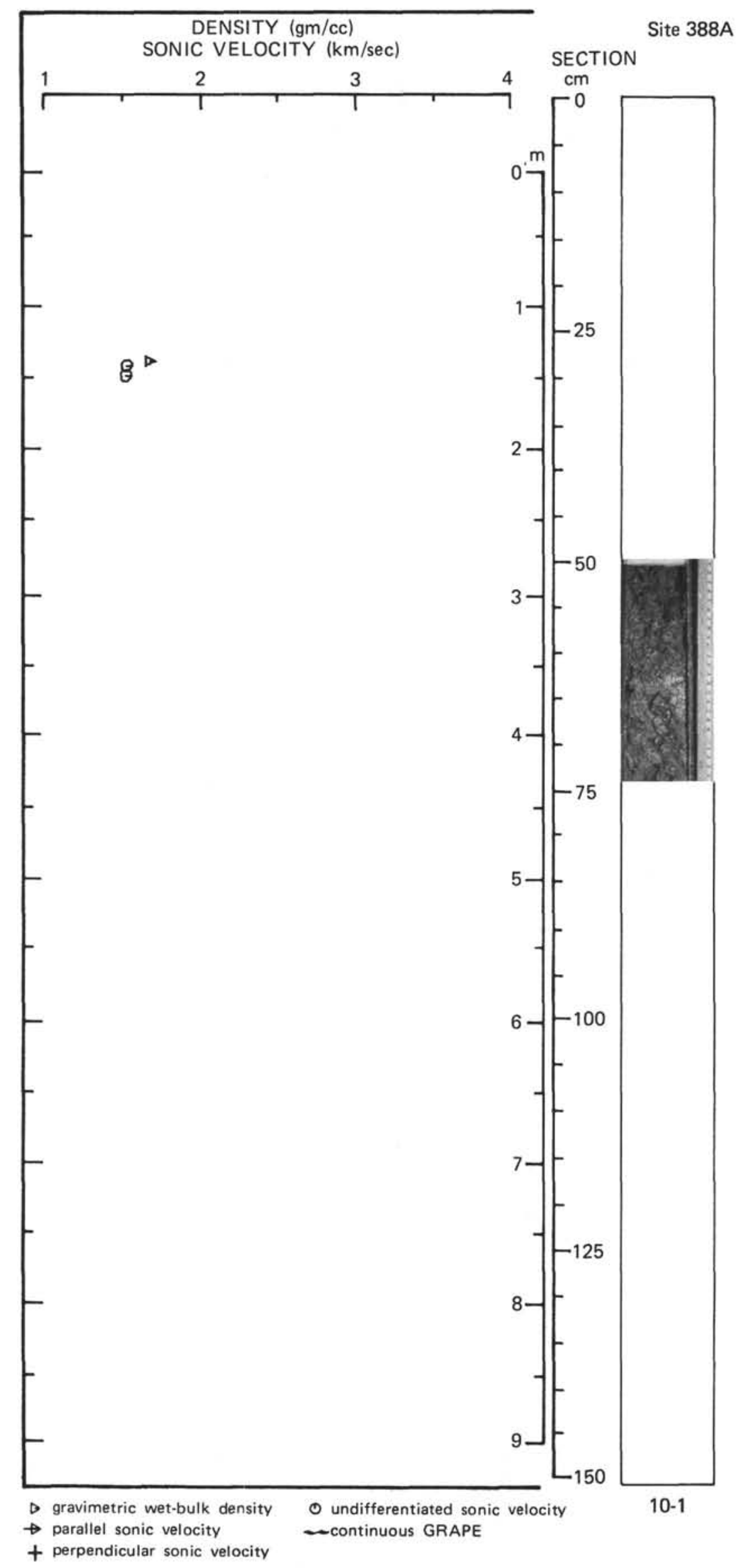




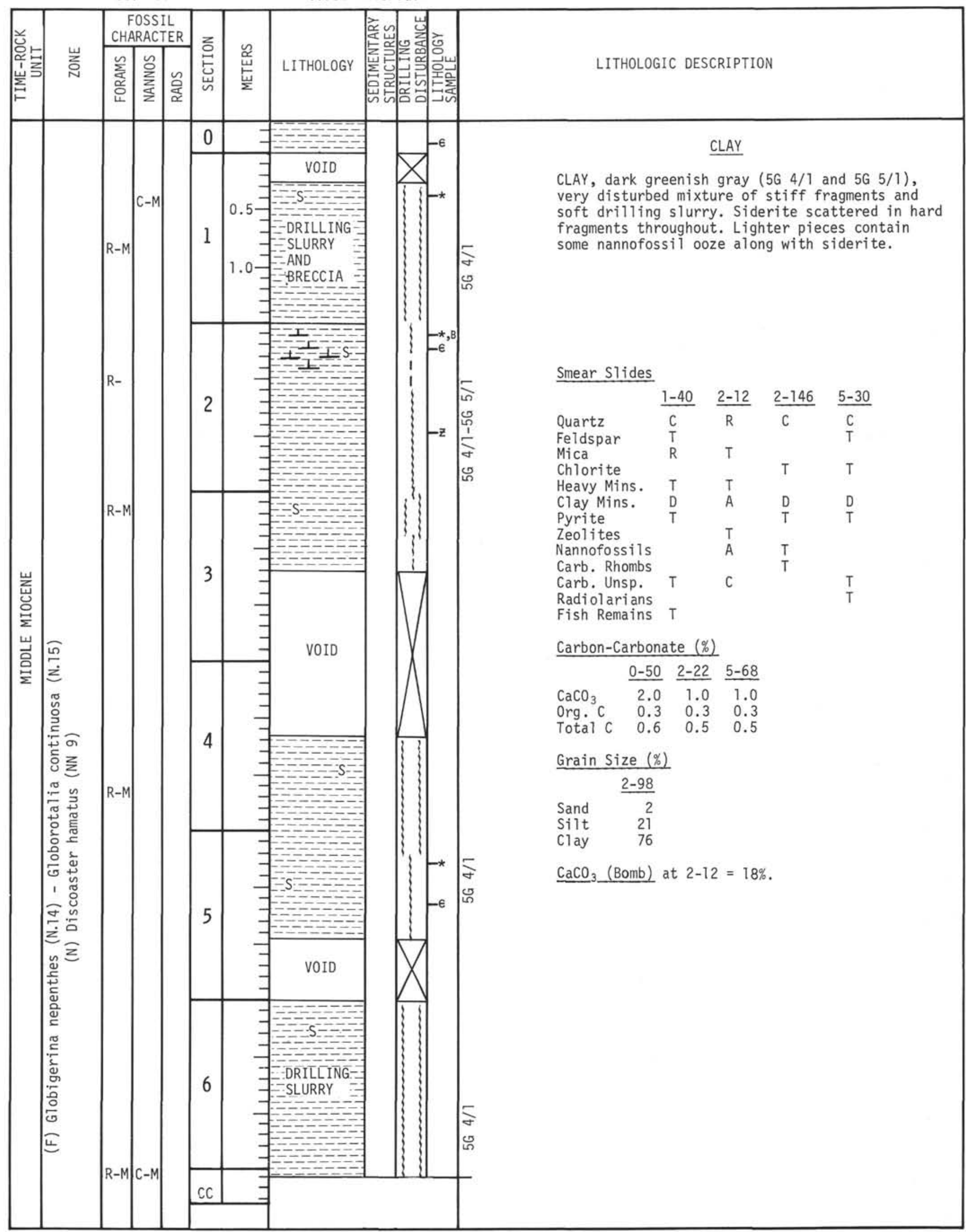




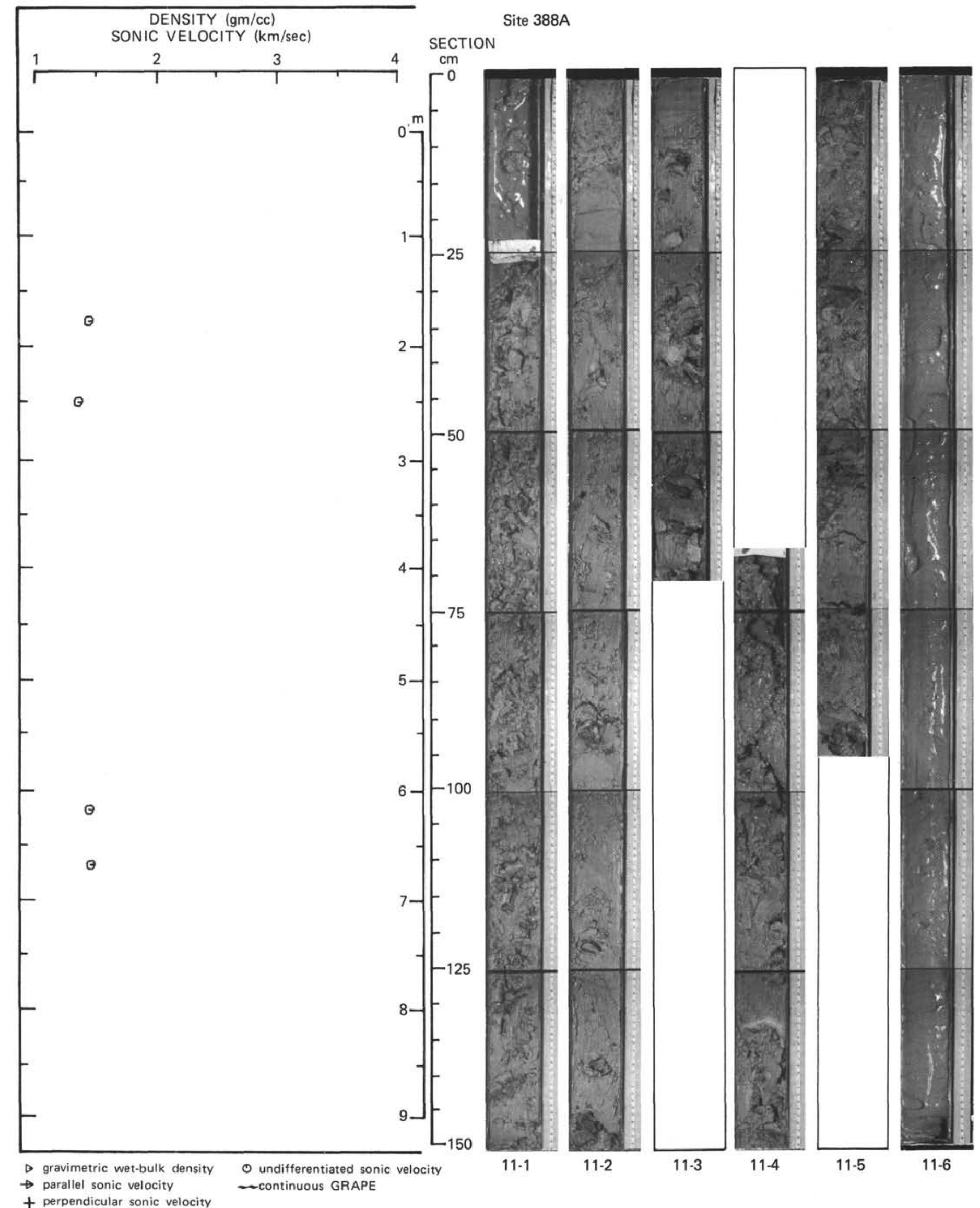

